JOÃO LEONARDO RODRIGUES MENDONÇA DIAS

ESTABELECIMENTO E CARACTERIZAÇÃO DE CÉLULAS-TRONCO

DE POLPA DENTÁRIA DE SUÍNOS

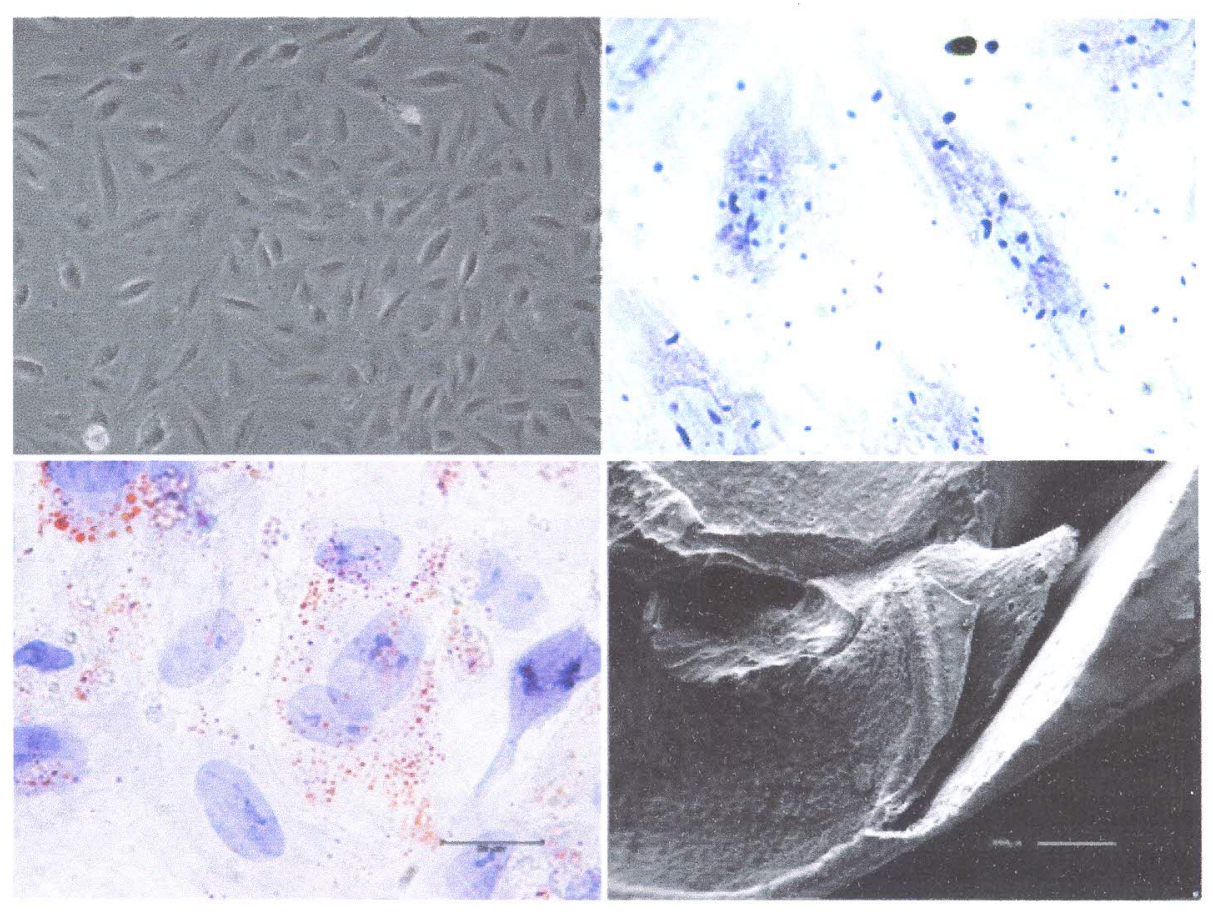

SÃO PAULO 
JOÃO LEONARDO RODRIGUES MENDONÇA DIAS

Estabelecimento e caracterização de células-tronco de polpa dentária de suínos 
JOÃO LEONARDO RODRIGUES MENDONÇA DIAS

\section{Estabelecimento e caracterização de células-tronco de polpa dentária de suínos}

Dissertação apresentada ao Programa de Pós-Graduação em Anatomia dos Animais Domésticos e Silvestres da Faculdade de Medicina Veterinária e Zootecnia da Universidade de São Paulo para obtenção do título de Mestre em Ciências

Departamento:

Cirurgia

Área de concentração:

Anatomia dos Animais Domésticos e Silvestres

Orientador:

Dra. Graciela Conceição Pignatari 
Autorizo a reprodução parcial ou total desta obra, para fins acadêmicos, desde que citada a fonte.

\section{BIBLIOTECA VIRGME OUFF DAPUE \\ FACULDADE DE MEDICINA VETERINARIA \\ E ZOOTECNIA DA USP \\ $7 / 12 / 124$}

\section{DADOS INTERNACIONAIS DE CATALOGAÇÃO-NA-PUBLICAÇÃO}

(Biblioteca Virginie Buff D’Ápice da Faculdade de Medicina Veterinária e Zootecnia da Universidade de São Paulo)

Dias, João Leonardo Rodrigues Mendonça

Estabelecimento e caracterização de células-tronco de polpa dentária de suínos / João Leonardo Rodrigues Mendonça Dias. - 2012 91 f. : il.

Dissertação (Mestrado) - Universidade de São Paulo. Faculdade de Medicina Veterinária Zootecnia. Departamento de Cirurgia, São Paulo, 2012.

Programa de Pós-Graduação: Anatomia dos Animais Domésticos e Silvestres.

Área de concentração: Anatomia dos Animais Domésticos e Silvestres.

Orientador: Dra. Graciela Conceiçāo Pignatari.

1. Cultura de células. 2. Células-tronco. 3. Polpa dentária. I. Título. 


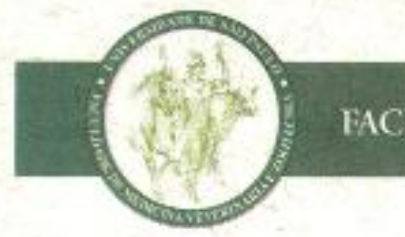

UNIVERSIDADE DE SÃO PAULO

ACULDADE DE MEDICINA VETERINÁRIA E ZOOIECNIA

\section{Comissão de Ética no uso de animais}

\section{CERTIFICADO}

Certificamos que o Projeto intitulado "Estabelecimento e caracterização de células-tronco de polpa dentária de suinos", protocolado sob o $n^{\circ} 2387 / 2011$, utilizando 5 (cinco) suínos, sob a responsabilidade da Profa. Dra. Patrícia Cristina Baleeiro Braga, está de acordo com os princípios éticos de experimentaçāo animal da "Comissäo de Ética no uso de animais" da laculdade de Medicina Veterinária e Zootecnia da Universidade de São Paulo e fơi aprovado em reuniăo de $17 / 8 / 2011$.

We certify that the Research "Establishment and characterization of stem cells from pig dental pulp", protocol number 2387/2011, utilizing 5 (five) pigs, under the responsibility Profa. Dra. Patricia Cristina Baleeiro Braga, agree with Ethical Principles in Animal Research adopted by "Ethic Committee in the use of animals" of the School of Veterinary Medicine and Animal Science of University of São Paulo and was approved in the meeting of day 8/17/2011.

Sāó Paulo, 10 de abril de 2012

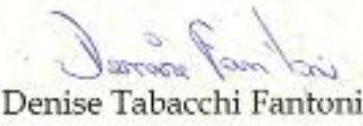

Presidente 


\section{FOLHA DE AVALIAÇÃO}

Nome: DIAS, João Leonardo Rodrigues Mendonça

Título: Estabelecimento e caracterização de células-tronco de polpa dentária de suínos

Dissertação apresentada ao Programa de PósGraduação em Anatomia dos Animais Domésticos e Silvestres da Faculdade de Medicina Veterinária e Zootecnia da Universidade de São Paulo para obtenção do título de Mestre em Ciências

Data:

Banca Examinadora

Prof. Dr.

Instituição: Julgamento:

Prof. Dr.

Instituição: Julgamento:

Prof. Dr.

Instituição: Julgamento: 


\section{DEDICATÓRIA}

Dedico este trabalho a Noeli, João e Isabel, minha família que incondicionalmente me proveu apoio e compreensão. Também o dedico a todos os amigos, colegas, professores e profissionais que direta ou indiretamente contribuíram para a conclusão deste. 


\section{AGRADECIMENTOS}

Agradeço a Professora Doutora Maria Angélica Miglino, coordenadora do programa de pós graduação em Anatomia dos Animais Domésticos e Silvestres da Faculdade de Medicina Veterinária e Zootecnia da Universidade de São Paulo, pela oportunidade cedida para participar deste seleto grupo de estudantes.

Agradeço a Professora Doutora Patrícia Cristina Baleeiro Beltrão Braga, pelo voto de confiança, e atendendo a um pedido, ter me aceito junto a seus orientados.

A Alan Melo, Antonio Assis, Carlos Ambrósio, José Kifouri, Paula Papa e Vicente Borelli, professores que me proporcionaram memoráveis aulas.

A Doutora Vivian Nunes, responsável pelo controle de qualidade do Frigorífico Suzano, que me forneceu as amostras necessária para a realização deste trabalho.

Ao Pr. José Bento e Joyce Moreira, por todo o empenho para que eu obtivesse os "protagonistas" deste experimento.

A toda direção desta distinta faculdade, tomo a liberdade de agradecê-los em nome do Professor Doutor José Antonio Visintin.

A todos os dedicados funcionários desta faculdade, onde invariavelmente recebi excelente e atencioso tratamento, agradeço em nome da chefe administrativo Daura Vaz Alves.

Ao amigo Ronaldo Agostinho, agradeço pelos incontáveis auxílios que recebi na histologia.

Aos colegas de pós-graduação, que junto a mim trilharam esse caminho, e que em especial cito: Aline, Amanda, André, Antenor, Bruno, Camila, Caroline, Cris, Day, Dilayla, Diogo, Eduardo, Eryka, "Fernandas" (Bastianelo, Cardoso e Menezes), Gaby, Gra, Gustavo, Luiz, Juliana, Larissa, Leandro, Marcos, Maria, Marina, Paula, Pedro, Phelipe, Renata, Sarmento, Silvia, Sonia, Thais, Valdir e Vitória. 


\section{AGRADECIMENTO ESPECIAL}

Mais do que agradecer, na verdade eu devo ao Grande Arquiteto do Universo a graça pela vida, saúde, condição e oportunidade de realizar este trabalho, e agradeço pelos anjos que Ele enviou para tomar conta de mim, que se chamam família e amigos. Alexander Fleming certa vez disse: Pouca ciência afasta o homem de Deus, muita ciência nos aproxima Dele, assim sendo, eu me realizaria em saber que mesmo que pouco, me aproximei do Senhor.

Em especial, agradeço a Isabella Fernandes, por me proporcionar incontáveis auxílios e aprendizados durante todo o tempo em que pudemos estar juntos. Amiga que fiz, constante e dedicada, com quem realizei vários experimentos, assim gerando um enorme sentimento de gratidão do "Joãozito" pela "Izoca".

Também em especial agradeço a Fabiele Baldino Russo, exemplo de abnegação, cuidado e entrega. Amiga turrona e presente, a que devo minha chegada até aqui, que nunca mediu esforços para me auxiliar, mesmo que para isso tivesse que ser implacável comigo. Por mais que eu tente, acredito que nunca conseguiria expressar a gratidão, carinho e respeito por você que existem em mim, mas mesmo assim queria que soubesse que o acredito que tudo o que você fez por mim transcende completamente o sentido da simples amizade.

Ainda em especial agradeço a Doutora Graciela Conceição Pignatari, uma irmã mais velha empenhada a ensinar os mistérios dos DMEM'S e CD'S. Cientista por natureza, contestadora e um pouquinho teimosa. Minha Orientadora, que mesmo sem me conhecer, esteve disposta a me guiar desde o começo, e que nunca furtou-se a puxar minhas orelhas ou elogiar meu desempenho, sempre que merecido, que compartilhou sua experiência com TODOS os integrantes do LCT, e que também compartilhou conosco a felicidade de conviver com a geração de uma forma da materialização do amor chamado Pedro.

Sinceramente, espero um dia estar em condições plenas de retribuir tudo o que de mais especial vocês fizeram por mim. Muito obrigado! 
"A ciência sem religião claudica. A religião sem a ciência é cega" Albert Einstein 


\section{RESUMO}

DIAS, J. L. R. M. Estabelecimento e caracterização de células-tronco de polpa dentária de suínos. [Establishment and characterization of stem cells from porcine dental pulp]. 2012. 91 f. Dissertação (Mestrado em Ciências) - Faculdade de Medicina Veterinária e Zootecnia, Universidade de São Paulo, São Paulo, 2012.

Os tecidos dentais apresentam-se como fontes abundantes e de fácil obtenção de células-tronco de diferentes tipos, como é o caso das células-tronco derivadas do epitélio dental, papila dental, ligamento periodontal e folículo dental que possuem origem ectomesenquimal oriundas da crista neural, com a exceção do epitélio dental que é oriundo do ectoderma. As células-tronco de polpa dentária humana (CTPD) expressam estavelmente marcadores de células-tronco adultas (CTA), CD105 e CD73 durante as passagens contínuas, e um grupo de antígenos estágios-específicos de superfície celular, SSEA-3, SSEA-4 e fatores de transcrição de células-tronco embrionárias (CTE) TRA1-60, TRA1-81, Oct-4 e Nanog. Além disso, estas células são capazes de se diferenciar in vitro em vários tipos de células e tecidos: cartilagem, osso, tecido neural, músculo liso e esquelético. Em suínos, modelo animal amplamente utilizado para o estudo de várias doenças encontradas em humanos, os dentes caninos possuem crescimento contínuo que pode ser uma característica bastante interessante quando pensamos em células-tronco. Dessa forma, o estudo das células de polpa dentária desse animal merece destaque. Neste trabalho visamos estabelecer o cultivo e a caracterização de células-tronco derivadas da polpa dentária dos dentes caninos dos suínos com crescimento contínuo (PDS) e dos dentes molares visando um estudo comparativo. O cultivo das células-tronco de polpa dentária de canino e molar foi estabelecido e de acordo com os nossos resultados podemos dizer que as células-tronco de polpa dentária de suíno são de fácil obtenção, já que o dente é descartado após o abate do animal e não tem nenhum valor comercial. Até o momento não observamos diferenças relacionados ao crescimento contínuo dos dentes caninos e as células-troncos isoladas possuem características mesenquimais como era esperado. $\mathrm{E}$ ainda, os resultados obtidos neste trabalho poderão contribuir para aquisição de uma nova fonte de células-tronco, cuja obtenção em abatedouros poderá ser contínua, aumento assim a quantidade podendo ser utilizada na Terapia Celular.

Palavras-chaves: Suínos. Cultura de células. Células-tronco. Polpa dentária. 


\begin{abstract}
DIAS, J. L. R. M. Establishment and characterization of stem cells from porcine dental pulp. [Estabelecimento e caracterização de células-tronco polpa dentária de suínos]. 2012. 91 f. Dissertação (Mestrado em Ciências) - Faculdade de Medicina Veterinária e Zootecnia, Universidade de São Paulo, São Paulo, 2012.

The dental tissue presents itself as an easy and abundant source to obtain stem cells of different types, such as stem cells derived from dental epithelium, dental papilla, periodontal ligament and dental follicle origin that have originated from ectomesenquimal neural crest, with the exception of dental epithelium that arises from the ectoderm. Stem cells from human dental pulp (TCDC) stably express markers of adult stem cells (CTA), CD105 and CD73 during continuous passages, and a group of stage-specific antigens of cell surface SSEA-3, SSEA-4 and transcription factors of embryonic stem cells (ESC) TRA1-60, TRA1-81, Oct-4 and Nanog. Furthermore, these cells are able to differentiate in vitro into cartilage, bone, neural tissue, skeletal and smooth muscle. In pigs, an animal model widely used for the study of several human diseases, the canine teeth continues to grow and can be a very interesting feature regarding stem cells. Thus, the study of dental pulp cells in this species is worthy consideration. The aim of this work was to establish the cultivation and characterization of stem cells derived from dental pulp from pigs' canine teeth with continuous growth (PDS) and the molar teeth, seeking a comparative study. The cultivation of stem cells from canine dental pulp and molar teeth have been established and, according to our results, we can say that stem cells from porcine dental pulp are easy to obtain, since the tooth is discarded when the animal is slaughtered and has no commercial value. So far no differences related to the continued growth of the canine teeth were observed and the isolated stem cells presented mesenchymal characteristics as expected. The results obtained in this study may contribute to the acquisition of a new source of stem cells, which can be obtained continuously in slaughterhouses, thus increasing the amount of samples to be used in cell therapy.
\end{abstract}

Keywords: Porcine dental pulp, Cell culture, Stem cell 


\section{LISTA DE FIGURAS}

Figura 1 - Esquema ilustrativo do dente de suíno e suas estruturas.

Figura 2 - Fotografia dos dentes de suínos em suas diferentes especializações.

Figura 3 - Fotomicrografia dos dentes após separação da polpa da coroa 40

Figura 4 - Fotografia do dente canino recebendo fragmentação mecânica.

Figura 5 - Fotomicrografia da polpa dentária recebendo colagenase I.

Figura 6 - Caracterização histológica dos dentes através da coloração de Hematoxilina e Eosina.

Figura 7 - Caracterização histológica dos dentes através da coloração de Tricromo de Masson.

Figura 8 - Ensaio imunohistoquimico apresentando marcação positiva para CD73 e CD105 e marcação negativa para CD34 e CD45.

Figura 9 - Ensaio imunohistoquimico apresentando marcação positiva para Oct4, Nanog e Sox2

Figura 10 - Ensaio imunohistoquimico apresentando marcação positiva para PCNA3 e Nanog, e marcação negativa para Controle

Figura 11 - Fotomicrografia da microscopia eletrônica de varredura realizada em dente canino

Figura 12 - Fotomicrografia da microscopia eletrônica de varredura realizada em dente molar

Figura 13 - Fotomicrografia da tentativa do estabelecimento da cultura celular pela técnica de explante

Figura 14 - Fotomicrografia do estabelecimento da cultura celular através da fragmentação mecânica associada à digestão enzimática no dia da cultura.

Figura 15 - Fotomicrografia da cultura celular após tripsinização .65

Figura 16 - Fotomicrografia das células-tronco derivadas de polpa dentária de caninos e molares após criopreservação

Figura 17 - Fotomicrografia das culturas derivadas de dentes caninos e molares

Figura 18 - Fotomicrografia realizada após a coloração por Hematoxilina e Eosina 
Figura 19 - Fotomicrografia das células-tronco de polpa dentária de caninos e molares suínos coradas por Azul de Toluidina

Figura 20 - Análise do perfil de expressão de CD73, CD105, Oct4 e Nanog nas células-tronco derivadas de dentes caninos.

Figura 21 - Análise do perfil de expressão de CD73, CD105, Oct4 e Nanog nas células-tronco derivadas de dentes molares de suínos

Figura 22 - Análise molecular por RT-PCR das células-tronco de polpa dentaria de dentes caninos de suínos

Figura 23 - Análise molecular por RT-PCR das células-tronco de polpa dentaria de dentes molares de suínos

Figura 24 - Fotomicrografia das células-tronco derivadas de dentes caninos após protocolo de diferenciação adipogênica, submetidas à coloração por oil red

Figura 25 - Fotomicrografia das células-tronco derivadas de dentes molares após protocolo de diferenciação adipogênica, submetidas à coloração por oil red

Figura 26 - Fotomicrografia das células-tronco derivadas de dentes caninos após protocolo de diferenciação osteogênica, submetidas à coloração por alizarina red

Figura 27 - Fotomicrografia das células-tronco derivadas de dentes molares após protocolo de diferenciação osteogênica, submetidas à coloração por alizarina red

Figura 28 - Análise macroscópica antes e após dissecação da região cervical de camundongos imunossuprimidos, nude que receberam inoculação de células-tronco oriunda de polpa dentária de suínos, de dentes caninos e molares

Figura 29 - Análise histológica de órgãos de camundongos imunossupromido nude após inoculação de células-tronco derivadas de dentes caninos, com ausência de indícios de neoplásicos

Figura 30 - Análise histológica de órgãos de camundongos imunossupromido nude após inoculação de células-tronco derivadas de dentes molares, com ausência de indícios de neoplásicos 


\section{LISTA DE GRÁFICOS}

Gráfico 1 - Análise de proliferação das células-tronco de polpa dentária de dentes caninos pelo método colorimétrico de MTT.....

Gráfico 2 - Análise de proliferação das células-tronco de polpa dentária de dentes molares pelo método colorimétrico de MTT. 


\section{LISTA DE QUADROS}

Quadro 1 - Oligonucleotideos utilizados na reação de PCR ..................................48 


\section{LISTA DE ABREVIATURAS, SIGLAS E SÍMBOLOS}

a.C

BSA

$\stackrel{\circ}{C}$

$\mathrm{CO} 2$

CT

CTA

CTE

CTG

CTM

CTPD

CTPDS

DAB

DAPI

DMEM

DMSO

FITC

FMVZ

$\mathrm{H}$

HE

$\mathrm{H}_{2} \mathrm{O}$

LCT

$\mathrm{MCl}$

MEM NEAA

$\mathrm{mL}$

MTT

Min

$\mathrm{nm}$
Antes de Cristo

albumina sérica bovina (Bovine Serum Albumin)

grau Celsius

dióxido de carbono

células-tronco

Célula-tronco adulta

Célula-tronco embrionária

Célula-tronco germinativa

Células-tronco mesenquimal

Célula-tronco de polpa dentária

Célula-tronco de polpa dentária de suínos

diaminobenzidina 3,3 '

40,6-diamidino-2- phenylindol

Dulbecco's Modified Eagle Medium

Dimetilsulfóxido

fluorescein isothiocyanate

Faculdade de Medicina Veterinária e Zootecnia

Horas

Hematoxilina \& Eosina

Água

Laboratório de Células Tronco

Massa celular interna

Aminoácidos não essenciais

Mililitro

(3-(4,5-Dimethylthiazol-2-yl)-2,5-diphenyltetrazolium bromide)

Minuto

Nanômetro 
Nanog

Oct-4

$\mathrm{pb}$

PCR

PBS

rpm

RT-PCR

SFB

TAE

$\mu \mathrm{L}$

$\mu \mathrm{m}$

$\mathrm{mm}$

$\%$

USP

UV
Nanog homeobox, em referência à Tir Nan Og

Fator de transcrição do Octâmero-4

Pares de base

Reação da polimerase em cadeia

Tampão salina-fostato

Rotações por minuto

Reverse transcriptase polymerase chain reaction

Soro Fetal Bovino

Tampão tris-acetato - EDTA

Micro-litros

Micrômetro

Milímetro

Por cento

Universidade de São Paulo

Ultravioleta 


\section{SUMÁRIO}

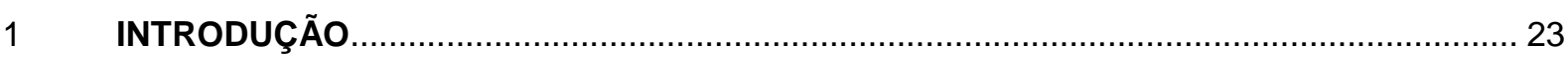

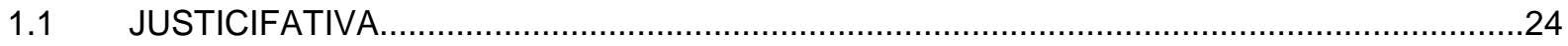

2 OBJETIVOS

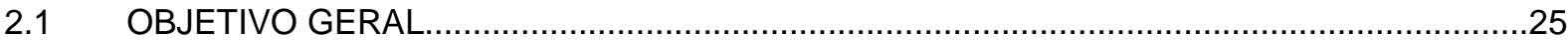

2.2 OBJETIVOS ESPECÍFICOS

$3 \quad$ REVISÃO DE LITERATURA

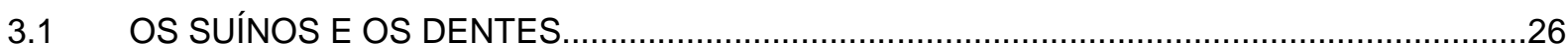

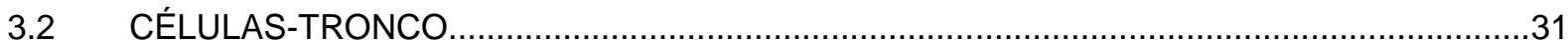

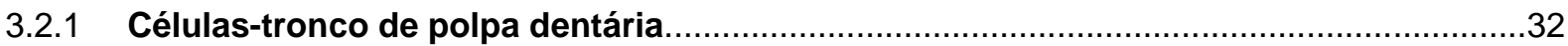

$4 \quad$ MATERIAIS E MÉTODOS

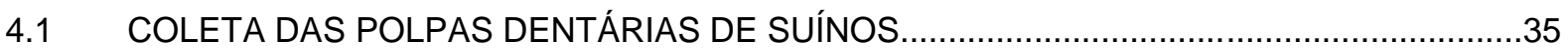

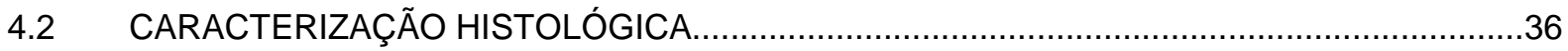

4.2.1 Coloração dos cortes de tecidos dentários pela técnica de Hematoxilina e Eosina.....37

4.2.2 Coloração dos cortes de tecidos dentários pela técnica de Tricromo de Masson..........37

4.2.3 Análise da espressão de CTM por imunohistoquimica ................................................38 
4.3.1 Cultivo das CTPDS processadas por explante.

4.3.2 Cultivo das CTPDS processadas por fragmentação mecânica associada a digestão enzimática.

4.4 ANÁLISE DE CRIOPRESERVAÇÃO DAS CÉLULAS-TRONCO DE POLPA DENTÁRIA DE SUÍNOS

4.5 CARACTERIZAÇÃO BIOLÓGICA DAS CÉLULAS-TRONCO DE POLPA DENTÁRIA DE SUÍNOS

4.5.1 Caracterização morfológica.

5.4.1.1 Análise morfológica das células-tronco de polpa dentária de suínos.

4.5.1.2 Análise morfológica das célula-tronco de polpa dentária de suínos por coloração de Hematoxilina -Eosina

4.5.1.3 Análise morfológica das célula-tronco de polpa dentária de suínos por coloração de Azul de Toluidina.

4.5.2.1 Ensaio de proliferação celular pelo método colorimétrico de MTT. 
4.6 ANÁLISE DE POTENCIAL CARCINOGÊNICO DAS CÉLULAS-TRONCO DERIVADAS DE POLPA DENTÁRIA DE SUIINOS.

4.6.1 Inoculação de células derivadas de dentes caninos e molares nos camundongos imunossuprimidos (nude).

4.6.2 Avaliação macroscópica da formação tumoral.

4.6.3 Avaliação microscópica da formação tumoral

$5 \quad$ RESULTADOS

5.1 CARACTERIZAÇÃO DO TECIDO DENTÁRIO.

5.1.1 Coloração de hematoxilina e eosina .53

5.1.2 Coloração de Tricromo de Masson

5.1.3 Análise imunohistoquímica do tecido dentário. .55

5.1.4 Análise da estrutural do dente por Microscopia Eletrônica de Varredura .59

5.2 CULTIVO DE CÉLULAS-TRONCO DE POLPA DENTÁRIA DE SUÍNOS .62

5.2.1 Cultivo das células-tronco de polpa dentária de suínos processadas por explante. 62

5.2.2 Cultivo das CTPDS processadas por fragmentação mecânica associada a digestão enzimática

5.3 ANÁLISE DE CRIORESERVAÇÃO DAS CÉLULAS-TRONCO DE POLPA DENTÁRIA DE SUÍNOS 
5.4 CARACTERIZAÇÃO BIOLÓGICA DAS CÉLULAS-TRONCO DE POLPA DENTÁRIA DE SUÍNOS

5.4.1 Caracterização morfológica

5.4.2 Análise morfológica das célula-tronco de polpa dentária de suínos por coloração de Hematoxilina e Eosina.

5.4.3 Análise morfológica das célula-tronco de polpa dentária de suínos por coloração de Azul de Toluidina

5.5.1 Ensaio de proliferação celular pelo método colorimétrico de MTT

5.5.2 Análise imunicotoquimica das células-tronco da polpa dentária de suínos. .72

5.6 CARACTERIZAÇÃO MOLECULAR DA CTPDS ATRAVÉS DE RT-PCR. .73

5.7 CARACTERIZAÇÃO FUNCIONAL. .76

5.7.1 Diferenciação adipogênica. .76

5.7.2 Diferenciação osteogênica.

5.8 ANÁLISE DE POTENCIAL CARCINOGÊNICO DAS CÉLULAS-TRONCO DERIVADAS DE DENTES CANINOS E MOLARES

5.8.1 Análise macroscópica após inoculo das células-tronco derivadas de dentes caninos e molares.

5.8.2 Análise histológica dos órgãos dos camundongos imunossuprimidos (nude) após inoculação das células derivadas de dentes caninos e molares por coloração de Hematoxilina e Eosina. 


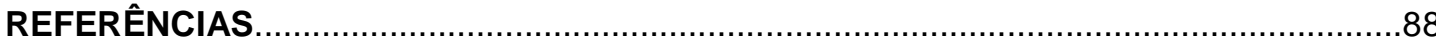




\section{INTRODUÇÃO}

Diversas patologias ainda permanecem sem tratamentos efetivos, restando apenas procedimentos paliativos, acarretando severas limitações à qualidade de vida de seus portadores, como exemplos podem citar os portadores de Diabetes, Alzheimer e Parkinson.

A terapia celular utilizando células-tronco tem surgido como uma alternativa de tratamento para essas e outras doenças, as quais os tratamentos atuais não têm surtido efeito curativo. O termo terapia celular pode ser definido como um procedimento médico que visa restabelecer a estrutura e a função de um tecido, por meio da utilização de uma célula ou de uma população de células. As intervenções médicas regenerativas ainda têm grandes limitações técnicas e biológicas e com isso, tais limitações motivam os cientistas a explorarem, cada vez mais os mecanismos biológicos envolvidos neste processo (CAPLAN, 2001, 2005).

Algumas características das células-tronco fazem com que estas se tornem especialmente atrativas para utilização em terapias celulares, como a questão de sua propriedade imunomoduladora, que permite o emprego de células em espécies distintas à da matriz doadora sem que ocorram ações deletérias como é o caso da rejeição entre doador e receptor de material biológico. Outro fator importante quando pensamos em células-tronco é a busca por qual a melhor fonte a ser utilizada para o isolamento destas células e por isso, várias fontes celulares vem sendo pesquisadas.

Pesquisadores têm demonstrado características importantes em relação às células-tronco de polpa dentária humana tais como: multipotência, clonogenicidade e proliferação, o que vem estimulando cada vez mais o estudo destas células em espécies diferentes que conservem similaridades com os humanos.

A carne suína é a mais consumida no mundo e a suinocultura brasileira é a quarta maior produtora mundial (CETESB, 2009; VENTURINI et al., 2009). Sendo, as estruturas dentárias inclusas no grupo de subprodutos do abatimento do suíno que possuem baixo ou nenhum valor comercial e na maioria das vezes é descartada nos abatedouros (VENTURINI et al., 2009), tornando se assim uma fonte de fácil obtenção. 
Além disso, o dente canino do suíno possui crescimento contínuo, o que os tornam bastante interessante quando pensamos em termos de células-tronco, podendo neste caso ter um nicho abundante destas células-tronco, sendo assim, um dos fatores que mais despertou interesse neste projeto. E ainda essa fonte se tornou mais atrativa quando pensamos na semelhança entre humanos e suínos.

Dessa forma, nesse projeto temos como objetivo estabelecer o cultivo de célulastronco de polpa dentária de suínos, dentes caninos e molares visando analisar se há relação entre crescimento contínuo e células-tronco, bem como obter células de uma nova fonte que além de fácil, grande quantidade ainda possui semelhanças significativas com os humanos.

\subsection{JUSTIFICATIVA}

A questão preponderante para usar a polpa dentária de suínos como fonte celular está justamente em seus dentes caninos apresentarem crescimento contínuo, o que possivelmente indica a existência de um nicho de células-tronco. Os dentes suínos não têm valor comercial e são descartados, facilitando a coleta e o estabelecimento de uma nova fonte celular. Podemos dizer ainda, que a facilidade na obtenção e o grande volume de animais abatidos, uma vez que, a suinocultura no Brasil encontra-se em quarta posição no mundo pode vir a ser uma grande oportunidade de obtenção destas células em larga escala. Convém ressaltar, que as células de polpa dentária humana possuem alta plasticidade, possível imunossupressão e vem sendo utilizada com sucesso em protocolos de terapia celular sendo possível pensar, que estas mesmas características podem estar conservadas na espécie suína o que torna o estudo destas células muito interessantes na terapia celular e na medicina regenerativa sendo os suínos modelos de grande proximidade com humanos. 


\section{OBJETIVOS}

\subsection{OBJETIVO GERAL}

Esse trabalho teve como objetivo estabelecer e caracterizar células-tronco de polpa dentária de dentes caninos, com crescimento contínuo e de molares, que não apresentam estas características, visando comparação entre eles. Além da caracterização celular um estudo histológico também foi realizado.

\subsection{OBJETIVOS ESPECÍFICOS}

- Obtenção dos dentes caninos e molares de suínos.

- Caracterização histológica das polpas dentárias (caninos e molares).

- Isolamento e cultivo de células-tronco derivadas de polpa dentária de dentes caninos e molares de suínos.

- Análise de proliferação celular das células-tronco por ensaio colorimétrico, MTT.

- Análise de criopreservação celular.

- Caracterização celular morfológica (Colorações de Hematoxilina \& Eosina, Tricromo de Masson e Microscopia Eletrônica de Varredura), celular (expressão de marcadores por ensaios imunocitoquímicos), molecular (RT-PCR).

- Análise do potencial carcinogênico das células-tronco obtidas em camundongos imunossuprimidos, nude. 


\section{REVISÃO DE LITERATURA}

\subsection{OS SUÍNOS E OS DENTES}

Acredita-se que a aparição dos suínos ocorreu aproximadamente há 40 milhões de anos, ainda sob uma forma primitiva e anterior ao Sus scrofa (Javali), sendo essa a espécie que originou o Sus domesticus. Sua domesticação é atribuída aos chineses por volta do ano 10.000 a.C., remontando aos resultados de pesquisas arqueológicas, que indicam que a principal fonte alimentar dos primeiros nômades a se fixarem eram justamente os suínos e não os cereais como por muito tempo foi postulado (SCHOELER, 2010). Portanto, a estreita ligação entre os humanos e os suínos é amplamente descrita desde os primórdios da humanidade e é vasta a gama de utilizações atribuídas a esse animal ao longo da história.

No mundo atual, a carne suína é a mais consumida e o Brasil ocupa a $4^{\underline{a}}$ posição na produção mundial desse produto. Atualmente é feito o direcionamento genético para obtenção de melhores resultados no que tange o aproveitamento da matéria, visando melhorias na saúde, dando resistência às doenças e defeitos congênitos, melhoria na qualidade da carne e nas características de produção, como habilidade materna, conversão alimentar e taxa de crescimento. Dessa forma atingindo amostras com menores taxas de gordura, melhoria da eficiência alimentar e favorecimento do crescimento do tecido magro, garantindo a heterogeneidade, e tornando cada vez mais saudável o hábito de apreciar a carne desse animal (CETESB, 2009).

Mesmo tendo-se passado vários anos desde o início das pesquisas envolvendo os suínos, ainda são necessários inúmeros estudos para obter-se uma quantidade satisfatória de informações sobre esse animal, exemplo disso é o fato que a fertilização in vitro de suínos possui uma margem de sucesso muito inferior e é mais cara quando comparado com bovinos, assim não sendo economicamente atrativa (IWASSAKI et al. 2000).

A escolha do porco como modelo animal para estudo de determinadas patologias humanas, detêm margem de confiabilidade maior quando comparado a 
modelos estabelecidos em camundongos, uma vez que o tamanho do suíno, bem como morfologia torácico-abdominal, fisiologia e longevidade se assemelham muito mais com o ser humano (BREVINI; PENNAROSSA; GANDOLF, 2010)

Os dentes dos suínos se desenvolvem de forma diferente em cada região da boca, conforme seu uso e são divididos em incisivos, caninos, pré-molares e molares. Cada espécie apresenta sua dentição característica quanto à forma e quantidade de dentes. Essa característica própria é denominada heterodontia (do grego "heteros", diferentes, e "odont" dente) (KÖNIG; LIEBICH, 2011).

Os dentes estão normalmente dispostos de forma simétrica bilateral, e em dois arcos, uma superior e um inferior, respectivamente nos ossos maxilar e mandibular. A porção que se sobrepõe a gengiva recebe o nome de coroa e a sustentação desta é realizada por uma ou mais estruturas denominadas raízes, que se unem aos alvéolos para tal (JUNQUEIRA; CARNEIRO 2010).

A coroa possui uma cobertura mineralizada extremamente dura chamada esmalte, ao passo que as raízes são revestidas pelo cemento. Ambos os revestimentos encontram-se no colo dentário. A dentina é constituída por outro tecido mineralizado, preenchendo o em torno da cavidade pulpar, que é formado por tecido conjuntivo frouxo ricamente inervado e vascularizado, em sua composição é facilmente encontrado fibroblastos, odontoblastos, finas fibrilas de colágeno e substância amorfa, rica em glicosaminoglicanos. Logo abaixo desta está localizado o forame apical que garante 0 acesso de vasos sanguíneos e linfáticos assim como nervos (Figura 1). A fixação do dente no alvéolo é realizada pelo ligamento periodontal, que é constituído por tecido conjuntivo com feixes grossos de fibras colágenas (JUNQUEIRA; CARNEIRO 2010). 
Figura 1 - Esquema ilustrativo do dente de suíno e suas estruturas

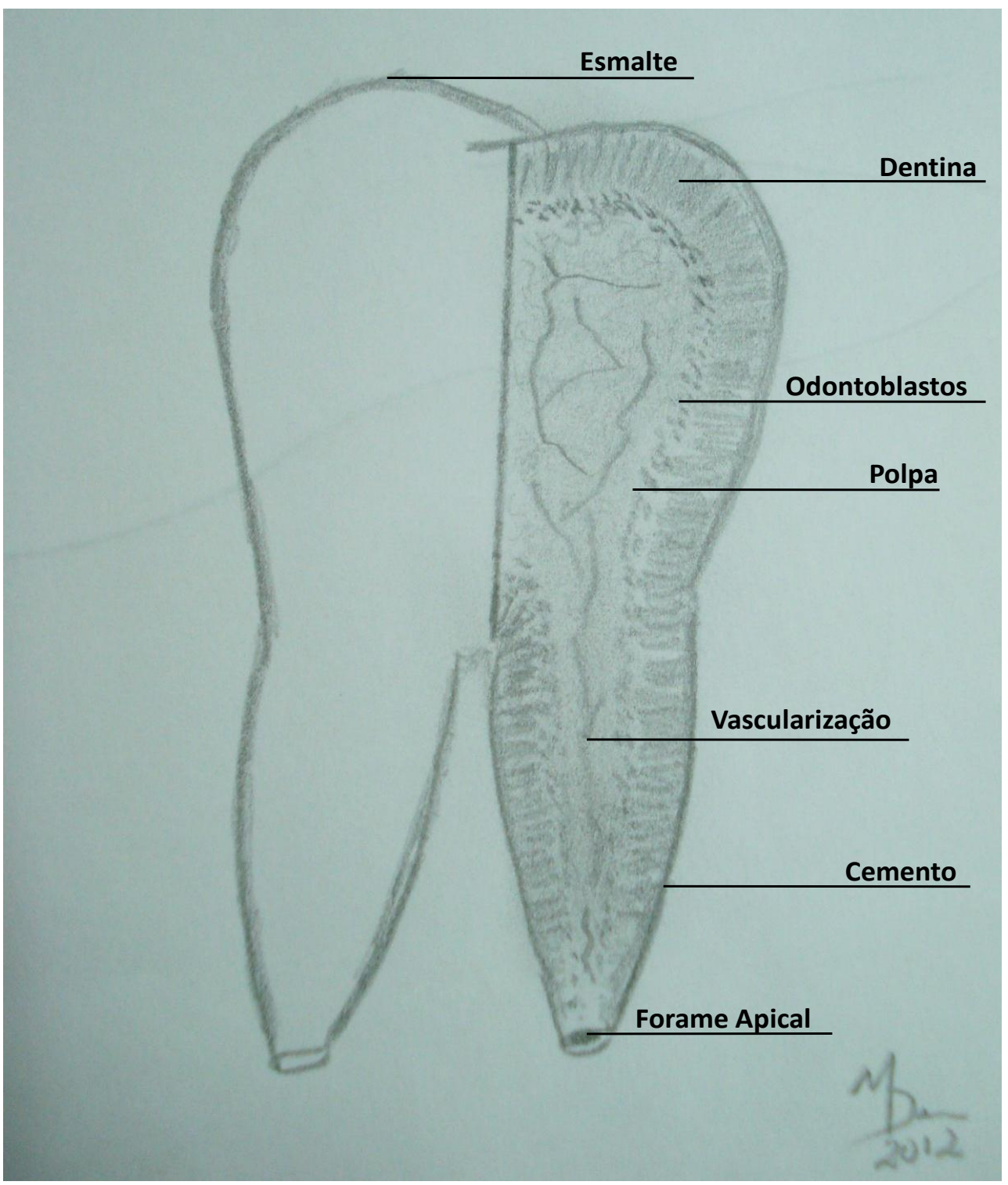

Fonte: (DIAS, J.L.M, 2012)

A dentição dos animais domésticos é difiodonte, cujos primeiros dentes ao nascer são substituídos por um conjunto único de dentes em animais mais velhos. Já, em outros vertebrados a dentição é polifiodonte, isso é sucessão múltipla, onde diversos conjuntos de dentes surgem ao longo da vida do animal (KÖNIG; LIEBICH, 2011).

Nos animais domésticos, o primeiro conjunto de dentes que surge são os dentes decíduos que estão presentes no nascimento ou nascem logo em seguida. Esses dentes são substituídos pelo segundo conjunto de dentes e se adaptam melhor à mandíbula que é maior e propicia uma mastigação mais forte ao animal adulto. O momento de substituição dos dentes decíduos varia entre as espécies, 
contudo a dentição permanente dos suínos começam a eclodir junto ao sexto mês, e esta só será concluída próximo ao décimo oitavo mês, ocasionando assim um longo período de dentição mista (KÖNIG; LIEBICH, 2011).

Embora todos os dentes sejam estruturas altamente especializadas, modificadas de acordo com a necessidade específica de cada espécie, eles compartilham uma arquitetura básica comum e divide-se em três partes: coroa, colo e raiz (Figura 1). A coroa é a parte exposta do dente, a qual se projeta para além da gengiva e é coberta por esmalte. O colo é a ligeira constrição localizada na linha da gengiva, onde termina o esmalte e a raiz é a parte abaixo da gengiva, cuja maior parte se encerra no alvéolo ósseo (Figura 1). Cada face dos dentes é indicada por uma denominação descritiva de importância fundamental no contexto clínico. As faces do dente que se volta para o vestíbulo da boca são as faces vestibulares, que podem ser indicadas mais precisamente com as expressões labial (voltado para os lábios) e bucal (voltado para as bochechas) e, a face adjacente à língua é a face lingual (KÖNIG; LIEBICH, 2011).

Os dentes caninos grandes e curvados também conhecidos como presas é a característica mais marcante da dentição suína, que crescem continuamente por toda a vida. Já, a face oclusal dos dentes molares se torna irregular devido à grande quantidade de tubérculos e é ideal para triturar o alimento (Figura 2).

De acordo com os postulados de Darwin, os exemplares mais adaptados de cada espécie conseguiriam perpetuar seus genes através de sua prole, dessa forma explícitas especializações podem ser percebidas nos diferentes tipos de dentes que compõem o início do tubo digestório dos suínos. Na figura 2, pode-se verificar a adaptação que possibilita o corte do alimento por parte dos dentes incisivos, a curvatura ântero-posterior existente no dente canino, para que este perfure e contenha a presa, bem como as coroas que possuem uma oclusão menos contundente, porém irregular e complementar aos seus análogos superiores, assim permitindo a mastigação dos alimentos (SISSON, 2005).

A figura 2 mostra a fotografia dos diferentes tipos de dentes de suínos e foi tirada no Museu de Anatomia Veterinária Profo Dro Plínio Pinto e Silva. 
Figura 2 - Fotografia dos dentes de suínos em suas diferentes especializações.
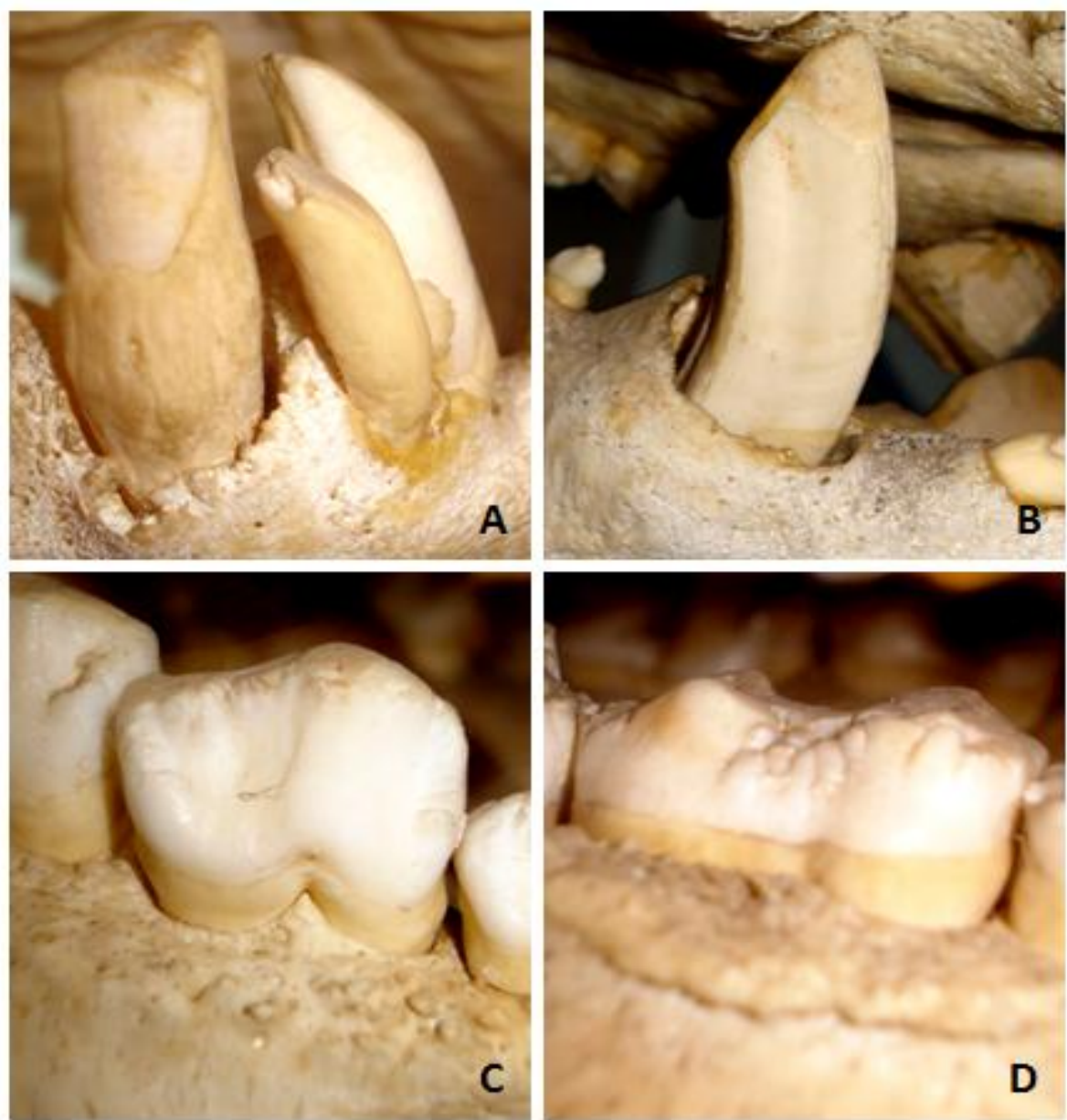

(Fonte: DIAS, J.L.R.M, 2012)

Legenda: A) Dente incisivo; B) dente canino; C) dentre pré-molar e D) dente molar.

Convém ressaltar que muitos criadores serram os dentes incisivos e caninos decíduos dos suínos logo após o nascimento o que costuma resultar em complicações médicas importantes. Ao passo que em bovinos, os dentes molares aumentam de tamanho da frente para trás. Esses dentes são hipsodontes, isso é de crescimento contínuo onde, o desgaste das coroas é compensado por este crescimento. Quando o crescimento se interrompe, as raízes são formadas e a altura da coroa clínica exposta é mantida pela extrusão gradual da parte incrustada até que o dente esteja totalmente consumido em animais velhos (NICKEL; SCHUMMER; SEIFERLE, 1979; KÖNIG; LIEBICH, 2011). 


\subsection{CÉLULAS-TRONCO}

As células-tronco (CT) se distinguem de outras células do organismo por apresentarem três características: são indiferenciadas, capazes de se multiplicar por longos períodos através da divisão celular e também de se diferenciar, ou se transformar em células especializadas com funções específicas, como por exemplo, uma célula cardíaca ou nervosa. As CT podem ser classificadas quanto ao seu potencial de diferenciação em: totipotentes são as formadas durante a fertilização até o estágio de 8 células e podem produzir qualquer tipo celular no organismo incluindo os anexos embrionários; pluripotentes: são as descendentes das CT totipotentes do embrião e se desenvolvem aproximadamente quatro dias após a fertilização, localizando-se na massa celular interna do blastocisto $(\mathrm{MCl})$, quando podem se diferenciar em tipos celulares provenientes das 3 folhetos embrionários, porém, elas não produzem as células das linhagens extra embrionárias; multipotentes são aquelas capazes de se diferenciarem em alguns tipos celulares específicos, ou seja, possuem plasticidade limitada; e ainda temos as unipotentes, células progenitoras que irão se diferenciar em apenas um tipo celular.

O primeiro grupo estabelecido durante o estágio evolutivo é o das células-tronco embrionárias, (CTE), derivadas da massa celular interna dos blastócitos, ou seja, células pluripotentes, enquanto as células-tronco germinativas (CTG) só poderão ser encontradas num estágio futuro, junto ao tecido fetal. Enquanto o terceiro grupo de células-tronco pode ser encontrado num individuo adulto, sendo estas as célulastronco adultas (CTA), responsáveis pelas reparações de possíveis injúrias que cometam o organismo em questão (CAPLAN, 2005). Ainda nesse grupo temos as células-tronco pós-natais ou fetais que podem ser as células isoladas do cordão umbilical, feto (material abortivo), placenta, membrana amniótica, saco vitelino e alantóide. Entretanto, acredita-se que as CTA não possuam as mesmas características que as CTE e CTG, no sentido de poderem ser precursoras de um organismo em sua totalidade (CAPLAN, 2005).

As células-tronco adultas ou mesenquimais (CTA ou CTM) foram isoladas pela primeira vez em 1970 por Frieddstein et al., a partir de material derivado de medula 
óssea que dispunham de capacidade de formar colônias in vitro, contendo células com morfologia semelhante a fibroblastos.

Com o passar do tempo diferentes fontes foram isoladas com o objetivo de obter células-tronco e muitas características foram sugeridas para que as mesmas fossem classificadas como tal. Para que houvesse então uma padronização, em 2005, o Comitê de Células-Tronco Mesenquimais e dos Tecidos da Sociedade Internacional de Terapia Celular, definiu que as Células-Tronco Mesenquimais (CTM) quando em cultura devem: ser aderentes ao plástico, expressar os marcadores CD105, CD73 e CD90 e não expressar os marcadores CD34, CD45, CD14, CD79A e HLA-DR, e diferenciar-se em condroblastos, osteoblastos e adipócitos quando cultivadas in vitro (DOMINICl et al., 2006).

\subsubsection{Células-Tronco de Polpa Dentária (CTPD)}

Os tecidos dentais são fontes de fácil acesso de diferentes tipos de CT, assim sendo, as CT derivadas desses tecidos são, na maioria, de origem ectomesenquimal, provenientes da crista neural, com a exceção do epitélio dental que é originado no ectoderma.

As CT extraídas de polpa dentária humana, CTPD, são multipotentes, altamente proliferativas e clonogênicas. Sendo ainda de fácil acesso e retiradas com mínimo desconforto para o paciente e, assim, as CTPD tornam-se uma fonte atrativa para ensaios clínicos e medicina regenerativa. Diversas populações de CT foram isoladas a partir de polpa dentária de dentes permanentes, decíduos e supranumerários (GRONTHOS et al., 2000; GRONTHOS et al., 2002; MIURA et al., 2003; LAINO et al., 2005; PIERDOMENICO et al., 2005; KERKIS et al., 2006; HUANG et al., 2008).

A primeira descrição das CTPD foi feita através da presença de células indiferenciadas de morfologia típica de fibroblasto na polpa do dente de ratos, as quais foram capazes de se diferenciar em odontoblasto, e subsequentemente produziram uma matriz de dentina (YAMAMURA, 1985). 
Em 2000, Gronthos et al conseguiram estabelecer a cultura de células-tronco obtidas a partir de polpa de dentes de pacientes adultos (CTPD) e apresentaram in vitro capacidade de formação de colônias e proliferação celular semelhantes as obtidas na medula óssea. Sendo que estas ainda, não apresentaram reação quando submetidas a ensaios de imunofenotipagem para marcadores hematopoiéticos, tais como: CD14, CD34 e CD45, ao passo que expressaram diversos marcadores associados a outras estruturas como: endotélio vascular, músculos, ossos, entre outros (ZANG et al. 2006). Estudos realizados pelo mesmo grupo, com célulastronco obtidas de polpa dentárias de dentes decíduos, demonstraram que estas apresentaram características muito semelhantes CTPD, porém com potencial proliferativo e clonogênico maior. Dessa forma, fazendo com que os tecidos dentais figurem como fontes de fácil acesso de diferentes tipos de CT, tendo sua maioria, origem ectomesenquimal, sendo ainda multipotentes, altamente proliferativos e clonogênicos (GRONTHOS et al., 2000; GRONTHOS et al., 2002).

Além disso, podemos dizer ainda, que o procedimento não apresenta desconforto algum para o doador de material junto à coleta representando uma fonte de amostras de grande interesse para estudos experimentais. Os autores demonstraram também à capacidade de diferenciação destas células tanto em adipócitos quanto em células nervosas (GRONTHOS et al., 2000; GRONTHOS et al., 2002)

Em 2006, as CT imaturas de polpa dentária foram também isoladas por outro grupo só que agora utilizando a técnica de explante em condições de cultivo similares às usadas para o isolamento de CTE (KERKIS et al., 2006). Essas células expressaram marcadores de CTE humanas como Oct-4 (fator de transcrição do Octâmero-4), Nanog (fator de transcrição, e fator chave da pluripotência), SSEA-3 e 4 (antígenos embrionários estágio-específico), TRA-1-60, TRA-1-81(antígenos de reconhecimento tumoral) e marcadores de CTM: CD105 (SH2), CD73 (SH3 e SH4), CD13 e CD31. Ainda, as CTIPD apresentam rápida proliferação, alta capacidade clonogênica e não apresentaram resposta imunológica quando injetadas em animais não imunossuprimidos (KERKIS et al., 2006). Em 2008, as CTPD foram testadas em ratos não imunossuprimidos para a reconstrução de defeitos cranianos produzidos e não obtiveram nenhuma rejeição (COSTA et al., 2008). 
Trabalhos com o intuito de isolar e caracterizar células-tronco a partir de polpa dentária de suínos já foram realizados, contudo a ênfase dada nos demais estudos era seu potencial de auto renovação, diferenciação em odontoblastos e modulação da proliferação de linfócitos $T$ visando obter esse tipo celular para uma possível utilização terapêutica (IOHARA et al. 2006; TANG; DING, 2011).

Entretanto, $\mathrm{O}$ isolamento proposto aqui com finalidade comparativa entre caninos e molares ainda não foi realizado. 


\section{MATERIAIS E MÉTODOS}

\subsection{COLETA DAS POLPAS DENTÁRIAS DE SUÍNOS}

As amostras foram obtidas a partir de 05 (cinco) mandíbulas desarticuladas de exemplares de Sus domesticus doadas pelo Frigorífico Suzano®, com aproximadamente 04 (quatro) meses de idade, após abate realizado através dos processos de dessensibilização elétrica, choque hipovolêmico e evisceração.

As mandíbulas foram lavadas em água-corrente, acondicionadas em saco de contenção, contendo $300 \mathrm{~mL}$ de Cloreto de Cocobenzil Alquil Dimetil Amônio a 0,45\% (Lysoform, São Paulo, Brasil) acrescidos de $2700 \mathrm{~mL}$ de água tratada pelo sistema de saneamento básico do Município de Suzano durante de 15 (quinze) minutos. Passado esse período, todo o material foi drenado e submerso em 2400 $\mathrm{mL}$ de solução de PBS contendo $2 \%$ de penicilina e estreptomicina (Invitrogen, CA, USA), e todo o material foi colocado em caixa térmica sob camada de material congelante reutilizável atóxico (Polar Técnica, São Paulo Brasil) e transportado até o Laboratório de Anatomia da Faculdade de Medicina Veterinária da Universidade de São Paulo (FMVZ-USP).

Com o emprego de Serra-Fita modelo HSF 3200/Seg (Hobart, São Paulo, Brasil) previamente limpa com álcool $70 \%$, as mandíbulas foram cortadas com a finalidade de extrair os dentes caninos, bem como os molares, sendo esses novamente submersos em PBS acrescido de 5\% de penicilina e estreptomicina (Invitrogen) e, imediatamente conduzidos ao Laboratório de Células-Tronco (LCT) da FMVZ-USP.

Convém ressaltar que uma amostra foi separada e submetida à análise histológica sendo colocada em paraformaldeído ou formol e a outra foi levada ao fluxo laminar sendo utilizada para o isolamento das células-tronco. 


\subsection{CARACTERIZAÇÃO HISTOLÓGICA}

Para a caracterização histológica dos tecidos dentários foram utilizadas dois exemplares de caninos e 2 de molares Os procedimentos histológicos foram realizados de acordo com os protocolos estabelecidos por Tolosa et al. (2003).

Os dentes foram fixados em formol 10\% (Sigma-ALdrich, St Louis, USA) para coloração de Hematoxilina-Eosina e paraformaldeído 4\% (Sigma-Aldrich) em tampão fosfato $0,1 \mathrm{M} \mathrm{pH} \mathrm{7,4} \mathrm{para} \mathrm{técnica} \mathrm{de} \mathrm{imunohistoquímica.}$

Os processos de fixação dos tecidos foram feitos por 72 horas a $4^{\circ} \mathrm{C}$. Após a fixação, os tecidos foram submetidos ao processo de descalcificação utilizando o descalcificador Osteomol 80\% por 21 dias (Merck Chemicals, Darmstadt, Alemanha). A condição propícia para aplicar os cortes histológicos foi aferida após a completa perfuração da amostra com o emprego de agulha sem o uso de força. A partir disso, os tecidos foram lavados em água corrente por 10 minutos e a desidratação foi feita usando imersões dos dentes em concentrações crescentes de etanóis $(70 \%, 80 \%$, $90 \%$ e, duas vezes de etanol $100 \%$ por uma hora cada. Em seguida, foi feita a etapa de diafanização com duas imersões em xilol por uma hora cada e os tecidos foram então incluídos em parafina líquida a $60^{\circ} \mathrm{C}$ (Histotec - Merck Chemicals) por 16 horas.

Após a polimerização da parafina, os blocos contendo as amostras foram cortados em micrótomo automático Leica RM2165 (Leica, Wetzear, Alemanha) produzindo cortes seqüenciais com aproximadamente $5 \mu \mathrm{m}$. Os cortes foram cuidadosamente assentados em lâminas histológicas e deixados em estufa a $60^{\circ} \mathrm{C}$ por 16 horas para uma melhor fixação das amostras e conseqüente evaporação do resíduo de parafina. 


\subsubsection{Coloração dos cortes de tecidos dentários pela técnica de Hematoxilina- Eosina}

Para realização da coloração por Hematoxilina-Eosina, os cortes de tecido dentário dos molares e caninos suínos foram desparafinizados com duas imersões em xilol, seguidas de imersões subseqüentes em concentrações de etanóis (100\%, 95\%, 70\%) por 10 minutos cada e por fim, uma imersão em água destilada de 5 minutos. Em seguida, as lâminas foram então colocadas na coloração de Hematoxilina de Harris (Sigma-Aldrich) por 1 minuto e depois em água corrente por 10 minutos, para remoção do excesso do corante. As lâminas foram então coradas em Eosina (Sigma-Aldrich) por 3 minutos posteriormente foi realizado o processo de desidratação com etanol $95 \%$ e duas imersões em etanol $100 \%$ por cinco minutos cada. As lâminas foram montadas com Permount@ (Fischer Scientific, Pittsburg, EUA).

\subsubsection{Coloração dos cortes de tecidos dentários pela técnica de Tricromo de Masson}

Para realização da coloração por Tricromo de Masson, os cortes de tecido dentário dos dentes molares e caninos dos suínos foram desparafinizados com duas imersões em xilol, seguidas de imersões subseqüentes em concentrações de etanóis $(100 \%, 95 \%, 70 \%)$ por 5 minutos cada e por fim, uma imersão em água destilada também por 5 minutos. Em seguida, as lâminas foram então colocadas na coloração de Hematoxilina de Harris (Sigma-Aldrich) por 1 minuto e depois em água corrente por 10 minutos, para que se removesse o excesso do corante. As lâminas foram então coradas em Fucsina Ácida Escarlate de Biebrich (Labsynth, São Paulo, Brasil) por 5 minutos, novamente submersas em água destilada por 5 minutos e corada por Ácido Fosfotúngtico (Merck) e Azul de Anilina Acética (Labsynth) por 10 minutos cada. $O$ excesso de corante foi removido em água destilada por 3 minutos, diferenciadas em Ácido Acético 1\% (Dinâmica, São Paulo, Brasil). Posteriormente foi realizado o processo de desidratação, a partir de uma sequência de etanóis em 
concentrações variadas (70\%, 95\% e 100\%), através de um mergulho rápido, e duas passagens de 5 minutos cada em Xilol e as lâminas foram montadas com Permount (Fischer Scientific).

\subsubsection{Análise da expressão de marcadores de CTM por imunohistoquímica}

Conforme relato anterior, os tecidos destinados à técnica de imunohistoquimica foram fixados em solução a $4 \%$ de paraformaldeído (SigmaAldrich), cortados e os cortes foram dispostos em lâminas silanizadas, preparadas previamente com 3-aminopropil-teirtoxi-silano (Sigma-Aldrich) por 30 minutos em estufa a $60^{\circ} \mathrm{C}$ para auxiliar na aderência dos cortes.

O procedimento foi iniciado com a desparafinização dos cortes realizada com a imersão dos mesmos, duas vezes em xilol por 10 minutos cada, etanol-xilol (1:1), etanóis $100 \%, 90 \%$ e $70 \%$, por três minutos cada, seguida de uma imersão em água destilada por 3 minutos. O desmascaramento dos sítios antigênicos foi feito em forno de micro-ondas usando tampão citrato a 10\% diluído em PBS (pH 6,0), por 3 vezes de 5 minutos ou até ferver.

O bloqueio da peroxidase endógena foi feito usando uma solução de água oxigenada (Merck) a 3\% diluída em metanol (Merck) por 5 minutos, no escuro. Em seguida, foi realizada lavagem em solução de PBS 0,1M contendo 0,05\% de Tween, (Vetec, Rio de Janeiro, Brasil) por 5 minutos. Para diminuir as possíveis reações inespecíficas, os cortes foram incubados com PBS contendo $2 \%$ de de soro albumina bovino (BSA) na estufa a $60^{\circ} \mathrm{C}$ por 30 minutos. Após o bloqueio, os anticorpos primários: anti-CD73, anti-CD105, anti-CD34, anti-CD45, anti-Oct4, antiNanog, anti-Sox-2, anti-PCNA3 e anti-vimentina (Santa Cruz Biotecnologia, CA, USA - concentração $200 \mu \mathrm{g} / \mathrm{mL}$ ) foram diluídos 1:50 em PBS 0,1M e incubados no período de 16 horas a $4^{\circ} \mathrm{C}$ em câmara úmida.

Os cortes foram lavados em PBS 0,1M contendo 0,05\% de Tween (Vetec) por 5 minutos cada lavagem e as lâminas foram incubadas com Advanced HRP Link (DAKO, CA, USA) por 30 minutos. A seguir, as lâminas foram novamente lavadas 3 vezes por cinco minutos cada em PBS contendo 0,05\% de Tween (Vetec) e,.posteriormente foi realizada a incubação com Advanced HRP Enzyme (DAKO) em 
temperatura ambiente por 30 minutos. Na sequencia foram realizadas 3 lavagens com PBS contendo $0,05 \%$ de Tween (Vetec) por 5 minutos cada.

A identificação das amostras marcadas com os anticorpos primários foi realizada utilizando o cromógeno diaminobenzidina 3,3' (DAB - DAKO)A incubação com DAB foi feita na ausência de luz, em temperatura ambiente, por aproximadamente 2 minutos, podendo variar de 1 a 3 minutos, de acordo com 0 anticorpo testado. Em seguida, três imersões foram realizadas para lavagens dos cortes com PBS contendo $0,05 \%$ de Tween, por 5 minutos. Para melhor visualização da imunohistoquímica, foi realizada uma coloração de fundo com Hematoxilina de Harris por 5 segundos e as lâminas foram imersas na água destilada por 5 segundos, para remoção do excesso de corante. Por fim, os cortes imersos em uma solução de água amoniacal a 0,5\% (Merck), por 3 vezes de 5 segundos cada, e posteriormente em água destilada por 5 segundos.

As amostras foram desidratadas, usando uma sequencia crescente de etanóis (70\%, 90\% e 100\%), por 30 segundos cada, uma imersão de etanol-xilol (1:1) por 5 segundos e uma imersão em xilol por 10 minutos. As lâminas foram montadas com Permount ${ }^{\circledR}$ (Fischer Scientifc).

\subsubsection{Análise estrutural do dente por Microscopia Eletrônica de Varredura}

Com a finalidade de analisar as características microscópicas das estruturas que compõem a unidade dentária, bem como suas divisões, o protocolo para microscopia eletrônica de varredura foi realizado.

Um exemplar de dente canino e outro de dente molar foram depositado em tubos cônicos de $50 \mathrm{~mL}$ e fixados $15 \mathrm{~mL}$ de glutaraldeído a 4 \% por 48 horas a temperatura ambiente. Após a fixação do material, os dentes foram acondicionados em caixas de isopor, com capacidade para aproximadamente $400 \mathrm{~mL}$, sendo imediatamente submergidos em nitrogênio líquido a $-196^{\circ} \mathrm{C}$. Para a execução das crio fraturas, choques mecânicos aleatórios forma promovidos, assim fragmentando os dentes congelados, após esse processo. Os fragmentos dos dentes caninos e molares foram pós-fixados em tetróxido de ósmio a 1\% (Labsynth) e desidratadas 
em série gradual de etanóis. Em seguida, foi realizada a secagem do material em aparelho de ponto crítico usando $\mathrm{CO}_{2}$ (CPD, Balzers Union, Liechtenstein) e por fim, as amostras receberam o recobrimento metálico com ouro por sputtering (K-550, Emitech, Kent, Inglaterra). Dessa forma, o processamento foi finalizado e o material foi submetido à análise no microscópio eletrônico de varredura (Leo 435 VP - Zeiss, Oberkochen, Germany).

\subsection{ISOLAMENTO E CULTIVO DAS CÉLULAS DE POLPA DENTÁRIA DE SUÍNOS}

Para a coleta da polpa dentária foi utilizado bisturi, pinça anatômica romba, lima odontológica e pinça anatômica fina-curva e toda a circunferência dos dentes, tiveram seus ligamentos periodontais rompidos com a finalidade de separa-se a coroa dentária (seta vermelha- Figura 3) da polpa dentária (seta azul - Figura 3), em fluxo laminar.

Figura 3 - Fotografia dos dentes molares e caninos após separação da polpa da coroa
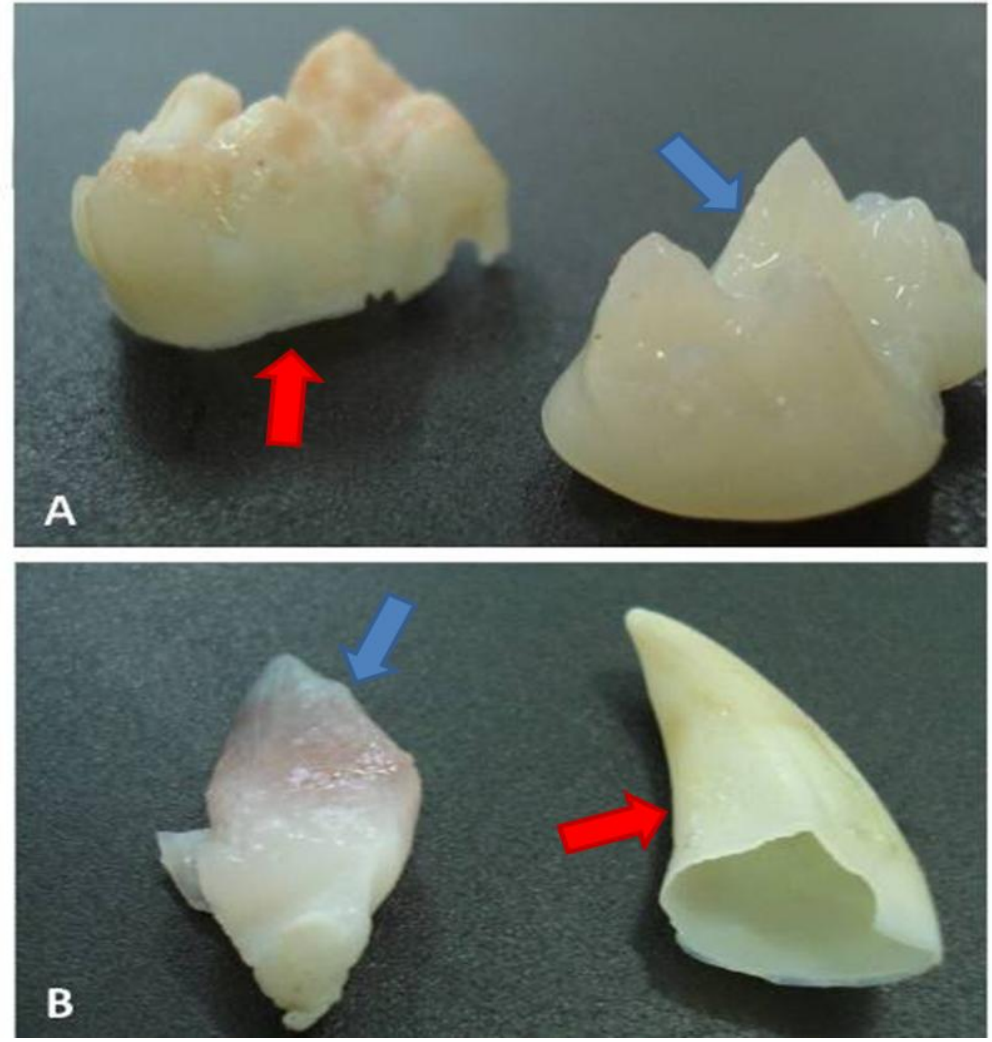

(Fonte: DIAS, J.L.R.M, 2012)

Legenda: A) Dente molar; B) Dente canino 
Para o estabelecimento do cultivo das células de polpa dentária de dentes caninos e molares de suínos foram testadas duas metodologia, assim descritas:

1) Técnica de explante;

2) Técnica de digestão enzimática com Colagenase tipo I.

\subsubsection{Cultivo das CTPDS processadas por explante}

As polpas dentárias isoladas como acima foram colocados em placas de Petri de poliestireno de $60 \mathrm{~mm}$ e submetidas a separação mecânica utilizando bisturi. Após obtenção de um homogenato de fragmentos (Figura 4), $2 \mathrm{~mL}$ de meio a-MEM suplementado com $20 \%$ de Soro Fetal Bovino (SFB - Invitrogen), 1\% de L-glutamina (Invitrogen), $1 \%$ de aminoácidos não essenciais (MEM NEAA Invitrogen) e $1 \mu \mathrm{L} / \mathrm{mL}$ de solução antibiótico-antimicótico (Sigma-Aldrich) foram adicionados. Imediatamente, as culturas foram conduzidas a incubadora e mantidas a $37^{\circ} \mathrm{C}$ sob atmosfera úmida contendo $5 \%$ de $\mathrm{CO}_{2}$.

Figura 4 - Fotomicrografia de dente canino recebendo fragmentação mecânica.

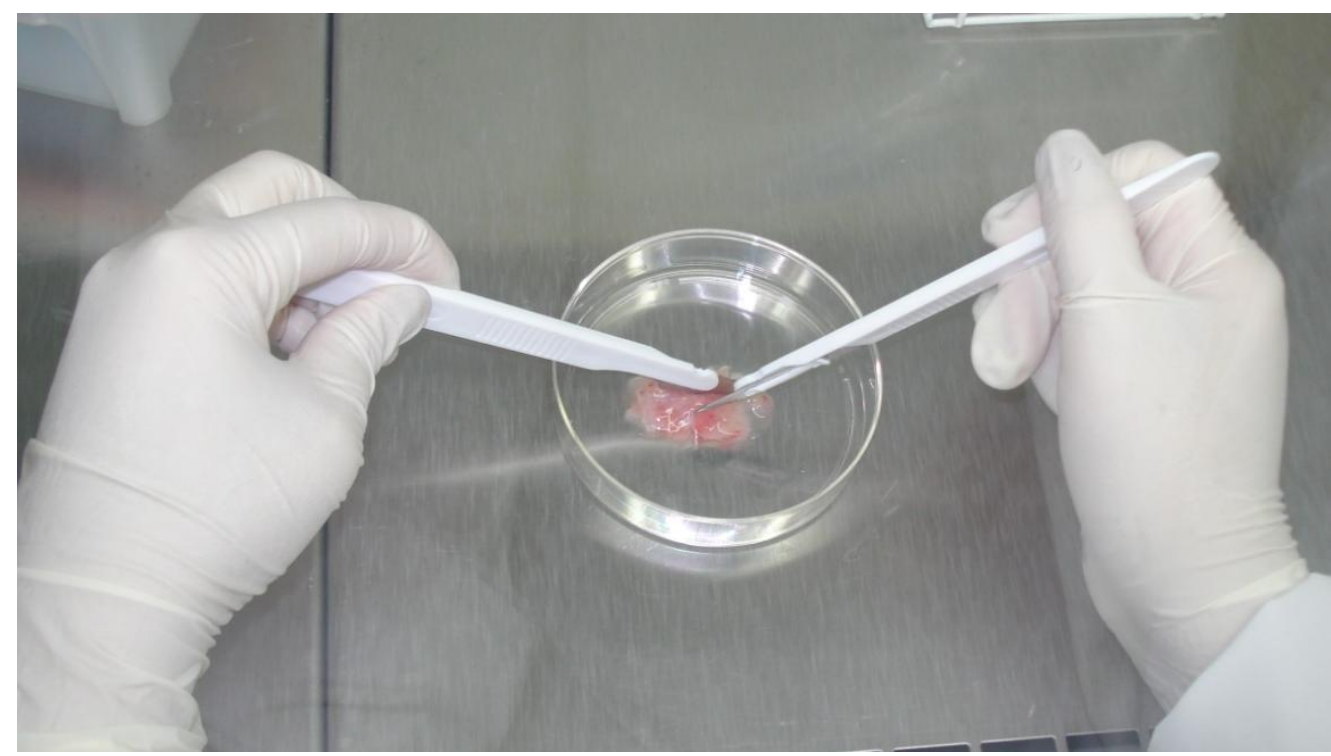

(Fonte: DIAS, J.L.R.M, 2012) 


\subsubsection{Cultivo das CTPDS após digestão enzimática com colagenase I}

A segunda metodologia empregada nesse trabalho constituiu na digestão enzimática onde das polpas dentárias de caninos e molares suínos foram tratadas com colagenase tipo I ( $3 \mathrm{mg} / \mathrm{mL}$ em PBS - Invitrogen - Figura 5), durante uma hora em banho-maria a $37^{\circ} \mathrm{C}$, alternando-se com cuidadosas agitações a cada 10 minutos.

Figura 5 - Fotomicrografia de polpa dentária recebendo colagenase I

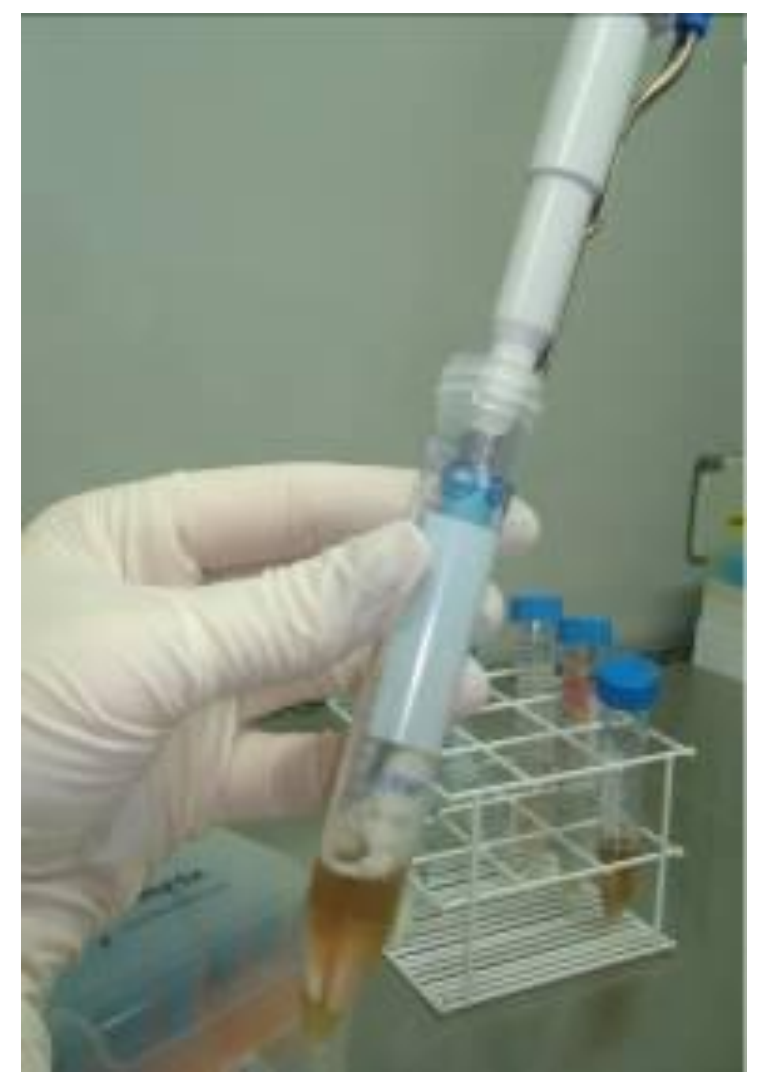

(Fonte: DIAS, J.L.R.M, 2012)

Após digestão, o homogeneizado acima foi inativado com $4 \mathrm{~mL}$ de meio de cultivo celular contendo SFB e centrifugado por 5 minutos a 1500 rpm. Após centrifugação, o sobrenadante foi descartado, o precipitado celular foi ressuspendido em $6 \mathrm{~mL}$ do meio supracitado e dividido em 3 (três) placas de Petri de poliestireno de $35 \mathrm{~mm}$. As células foram mantidas a $37^{\circ} \mathrm{C}$ sob atmosfera úmida contendo $5 \%$ de $\mathrm{CO}_{2}$ e o meio de cultura foi substituído a cada dois dias ou de acordo com a necessidade. 
Após aproximadamente 24 horas da coleta, tanto células como tecidos remanescentes aderiram na placa e houve desprendimento celular.

Quando as células atingiram semiconfluência elas foram submetidas ao repique celular. Para tanto, foram lavadas com PBS e, posteriormente $0,5 \mathrm{~mL}$ de tripsina $0,25 \%$ (LGC) foram adicionados. Passado o tempo de incubação de 5 minutos, as células foram levadas ao microscópio óptico para observação do descolamento celular. Após o descolamento celular total, 2-4 mL de meio de cultivo foram adicionados para inativação da tripsina.

Neste momento, a quantidade final de células foi divida em duas placas de Petri de poliestireno de $35 \mathrm{~mm}$ e $2 \mathrm{~mL}$ de meio de cultivo foram adicionados em cada placa e as células foram mantidas em atmosfera úmida de $5 \%$ de $\mathrm{CO}_{2}$ a $37^{\circ} \mathrm{C}$.

Dessa forma, as células foram expandidas para os experimentos seguintes e o repique celular foi realizado conforme necessidade, seguindo o protocolo descrito acima.

\subsection{ANÁLISE DA CRIOPRESERVAÇÃO DAS CÉLULAS-TRONCO DE POLPA DENTÁRIA DE SUÍNOS.}

O procedimento de congelamento foi iniciado com a lavagem das células com PBS, seguida de tripisinização. Após tripsinização, as células foram submetidas à centrifugação por 5 minutos a $1500 \mathrm{rpm}$ e o precipitado formado foi ressupendido em solução de congelamento contendo: $90 \%$ de SFB (Invitrogen), e 10\% de dimetilsulfóxido (DMSO - LGC). Em seguida, os tubos foram colocados por $24 \mathrm{~h}$ em freezer $-80^{\circ} \mathrm{C}$ e posteriormente transferidos ao nitrogênio liquido. Após 45 dias do congelamento, as células foram descongeladas rapidamente em banho-maria e colocadas em cultivo com o objetivo de analisar se as mesmas conservam suas características após congelamento. 


\subsection{CARACTERIZAÇÃO BIOLÓGICA DAS CÉLULAS-TRONCO DE POLPA DENTÁRIA DE SUÍNOS}

A caracterização biológica das células-tronco de polpa dentária de suínos realizadas neste trabalho constituiu em caracterização morfológica (microscopia de luz, colorações de HE e toluidina e microscopia eletrônica de varredura e transmissão), celular (análise de proliferação celular pelo ensaio colorimétrico de MTT, imunofenotipagem através de ensaios imunocitoquímicos), molecular (RTPCR) e funcional (diferenciações adipo, osteo e condrogênica).

\subsubsection{Caracterização Morfológica}

A morfologia das células-tronco derivadas da polpa dentária de suínos foi visualizada diariamente em microscopia de luz sem ou após colorações com HE e azul de toluidina e por microscopia eletrônica de varredura e transmissão.

4.5.1.1 Análise morfológica das células-tronco de polpa dentária de suínos

As células derivadas de dentes caninos e molares em cultivo foram submetidas à análise morfológica por microscopia de luz, em microscópio óptico invertido (Nikon Eclipse TS100 - Japão) e fotografado semanalmente.

4.5.1.2 Análise morfológica das células-tronco de polpa dentária de suínos por coloração de Hematoxilina e Eosina

Com a finalidade de analisar a morfologia destas células, as células-tronco de polpa dentária de caninos e molares foram submetidas à coloração de Hematoxilina- 
Eosina. Para isso, as células foram cultivadas em placa de $35 \mathrm{~mm}$.e após as 24 horas de cultivo, foram fixadas com paraformaldeído 4\% (Merck) por 30 minutos. Em seguida, as células foram lavadas com PBS para a retirada do excesso de fixador, coradas com hematoxilina (Merck) por 5 minutos e novamente lavadas com PBS. As células foram coradas pela eosina (Merck) por 3 minutos e novamente lavadas com PBS para a retirada do excesso de corante, Por fim, as lâminas foram montadas com o emprego de Permount (Fischer Scientific) e devidamente fotografadas através de microscopia de luz (Nikon Eclipse 80i e programa NIS Elements version 3.22, Tokio, Japan).

4.5.1.3 Análise morfológica das células-tronco de polpa dentária de suínos por coloração de Azul de Toluidina

Ainda com o intuito de averiguar a morfologia das células-tronco derivadas de dentes caninos e molares, a coloração de azul de toluidina foi realizada. Para tanto, as células foram cultivadas em placas de $35 \mathrm{~mm}$, fixadas com paraformaldeído $4 \%$ (Merck) por 30 minutos. Em seguida, as células foram lavadas com PBS para retirada do excesso do fixador e coradas com azul de toluidina (Merck) durante 10 minutos. Passado esse período de incubação, o corante foi retirado e a placa lavada com PBS, as lâminas foram montadas com o emprego de Permount (Fischer Scientific) e as células foram analisadas através de microscopia de luz e a morfologia observada registrada fotograficamente em microscópio óptico (Nikon Eclipse 80I).

\subsubsection{Caracterização celular}

4.5.2.1 Ensaio de proliferação celular pelo método colorimétrico de MTT

O ensaio colorimétrico de proliferação celular MTT, descrito por Carmicheal et al. (1987), consiste na redução do MTT (3-[(4,5- dimethylthiazol-2-yl)- 2,5- 
diphenyltetrazolium bromide] - Sigma-Aldrich), composto de coloração amarela, pela enzima desidrogenase mitocondrial (componente do complexo II do ciclo de Krebs), presente somente em células viáveis, gerando formazan, composto azul-violeta. $\mathrm{O}$ formazan uma vez precipitado a 1000 rpm por 10 minutos e solubilizado em DMSO, é quantificado por espectrofometria a $550 \mathrm{~nm}$.

O experimento foi realizado a cada 48 horas durante 9 dias para análise da proliferação celular das células-tronco de polpa dentária de suínos. Para tanto, aproximadamente 1 e $5 \times 10^{3}$ células foram plaqueadas em placas de 96 orifícios em um volume de $100 \mu \mathrm{L} /$ poço para cada dia de experimento.

Em cada dia de experimento, o meio de cultura foi removido, as células foram lavadas com $100 \mu \mathrm{L} /$ poço e adicionou-se $100 \mu \mathrm{L}$ de solução de MTT (1 mL de MTT a $5 \mathrm{mg} / \mathrm{mL}$ em $10 \mathrm{~mL}$ meio de cultivo contendo $1 \%$ de SFB). Essa mistura foi incubada por 3 horas a $37^{\circ} \mathrm{C}$ protegida da luz. Após esse período, o formazan foi precipitado a 1000 rpm durante $10 \mathrm{~min}$, solubilizado em $50 \mu \mathrm{L}$ de DMSO (LGC). Em seguida, a leitura foi realizada em espectrofotômetro (M-Quant - Bio Tek Instruments, VT, USA) no comprimento de onda de $550 \mathrm{~nm}$.

Os resultados obtidos neste experimento foram plotados em um gráfico de barra utilizando o programa GraphPad (GraphPad Software, CA, USA).

5.5.2.2 Análise imunocitoquímica das células-tronco de polpa dentária de suínos

As células-tronco derivadas da polpa dentária de caninos e molares foram cultivadas em placas de 24 orifícios sob a lamínula de vidro até atingirem a confluência desejada em torno de $80 \%$. Em seguida, as células foram lavadas por 3 vezes de 5 minutos cada em PBS e fixadas em $4 \%$ de paraformaldeído durante 15 minutos em temperatura ambiente. Após fixação, as células foram lavadas com PBS por 3 vezes de 5 minutos cada.

Em seguida, as células foram submetidas ao bloqueio em PBS contendo $2 \%$ de BSA durante 4 horas a temperatura ambiente. Após o bloqueio, as células foram 
incubadas com anticorpos primários, anti-CD105, anti-CD73 (SantaCruz Biotechnology - concentração $200 \mu \mathrm{g} / \mathrm{mL}$ ), diluídos 1:50 em câmera úmida por 16 horas a $4^{\circ} \mathrm{C}$. Após o período de incubação dos anticorpos primários, as células foram lavadas por três vezes com PBS e submetidas ao bloqueio em PBS contendo $2 \%$ de soro albumina bovino (BSA) durante 1 hora a temperatura ambiente. Posteriormente, os anticorpos secundários diluídos 1:200 marcados com Alexa Fluor 488 (Invitrogen) foram adicionados e incubados por 1 hora em temperatura ambiente. Ao final, as células foram lavadas por 3 vezes por 5 minutos cada e as lâminas foram montadas em meio de montagem Vectashield (Vector Laboratories, CA, USA). A imunoreatividade foi avaliada em microscopia de epifluorescência Eclipse 80i e no programa NIS Elements version 3.22 Nikon (Nikon, Tókio, Japan).

\subsubsection{Caracterização molecular através de RT-PCR}

Para a caracterização molecular de RT-PCR, o meio das células-tronco de polpa dentária de caninos e molares foi removido e as células foram lavadas duas vezes com PBS. Após remoção total do PBS, $1 \mathrm{~mL}$ de Trizol (Invitrogen) foi adicionado, as células foram homogeneizadas nas placas e transferidas para tubos de microcentrifuga onde adicionou-se $0,5 \mathrm{~mL}$ de clorofórmio. Após gentil homogeneização, as células foram centrifugadas a $12000 \times \mathrm{g}$ durante $15 \mathrm{~min}$ a $4^{\circ} \mathrm{C}$.

Em seguida, a fase incolor obtida após a centrifugação foi cuidadosamente retirada e $0,5 \mathrm{~mL}$ de álcool isopropílico foram adicionados para a precipitação do RNA e mantido por 16 horas a -20․ Após esse período, o conteúdo foi centrifugado a $12000 \mathrm{x}$ g durante $10 \mathrm{~min}$ a $4^{\circ} \mathrm{C}$ e o precipitado incolor obtido foi lavado com etanol $70 \%$, preparado em água DEPC (dietilpirocarbonato) e novamente centrifugado a $7500 \times \mathrm{g}$ durante 5 min a $4{ }^{\circ} \mathrm{C}$.

Posteriormente, o etanol foi removido e o precipitado secou ao ar livre durante aproximadamente 10 minutos. Após secagem, o RNA foi ressuspendido de acordo com o tamanho de seu precipitado em água DEPC. Dessa forma, o RNA obtido foi submetido à eletroforese em gel de agarose $1 \%$ e corado com brometo de etídeo para visualização da 
qualidade do RNA. Em paralelo, o RNA foi dosado por espectrofotometria utilizando o nanofotômetro (Implen, CA, USA) e, posteriormente utilizado na síntese do cDNA.

A síntese de cDNA, uma solução contendo $1 \mu \mathrm{g}$ de RNA, $10 \mathrm{mM}$ de dNTP, oligo dT $(0,5 \mu \mathrm{g} / \mu \mathrm{L})$ e água tratada com DEPC foi aquecida durante $65^{\circ} \mathrm{C}$ durante 5 minutos. Após este procedimento, as amostras foram colocadas no gelo e adicionou-se tampão da enzima, $25 \mathrm{~mm}$ de $\mathrm{MgCl}_{2}, 0,1 \mathrm{M}$ de DTT e 40U/ $\mu \mathrm{L}$ da enzima RNaseOUT (Invitrogen) para a síntese do cDNA seguindo as instruções do fabricante. Esta mistura foi então submetida a uma temperatura de $42^{\circ} \mathrm{C}$ durante $2 \mathrm{~min}$. Em seguida, $1 \mu \mathrm{L}$ da enzima SuperScript II RT foi adicionado e incubado a $42^{\circ} \mathrm{C}$ durante 50 minutos, a reação foi terminada a $70^{\circ} \mathrm{C}$ durante 15 min e, posteriormente armazenada em - 20ำ até a sua utilização.

Após síntese, os cDNAs foram utilizados como fita molde na reação de PCR, para tanto, misturou-se $2 \mu \mathrm{L}$ cDNA, 0,2 $\mu \mathrm{M}$ de oligonucleotídeos sense e anti-sense que anelam nos genes de interesse (Quadro 2), 0,2 $\mu \mathrm{M}$ dNTPs, $\mathrm{MgCl}_{2}$ 1,5 mM, tampão da

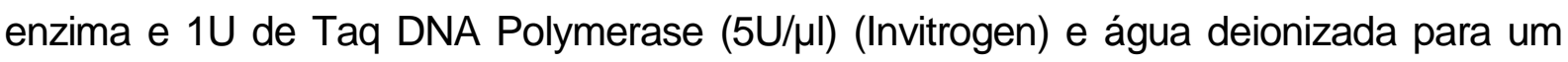
volume final de $25 \mu \mathrm{l}$. Esta mistura foi colocada em um termociclador e a reação ocorreu nas seguintes condições: 1 ciclo a 94ㅇ $\mathrm{C}$ por 4 min seguindo 35 ciclos de variações consecutivas de temperatura: 94ำ $\mathrm{C}$ por 1 min para desnaturação, 60ำ $\mathrm{C}$ por 1 min para anelamento e $72^{\circ} \mathrm{C}$ por 1 min para polimerização e 1 ciclo extra de $10 \mathrm{~min}$ a $72^{\circ} \mathrm{C}$ para a extensão final.

Aproximadamente $10 \%$ do produto desta reação foram submetidos à eletroforese em gel de agarose 1,5\% e corado com SYBR SAFE DNA STAIN (Invitrogen) para visualização em transiluminador UV. Marcador de peso molecular, Gene Ruler 100pb DNA Ladder foram utilizados para confirmar o tamanho esperado dos fragmentos.

Quadro 1 - Oligonucleotídeos utilizados na análise molecular por RT-PCR

\begin{tabular}{|c|c|c|}
\hline Gene & Sentido & Sequência \\
\hline Sox 2 & $S$ & AATGCCTTCATGGTGTGGTC \\
\hline Sox 2 & AS & CGGGGCCGGTATTTATAATC \\
\hline CD34 & $\mathrm{S}$ & TTCTGTCCAGCCTCAGACCT \\
\hline CD34 & AS & GCTACCTGGGGTAGGAGGAG \\
\hline CD45 & $\mathrm{S}$ & GGACATGTGACCTGGAAACC \\
\hline CD45 & AS & CCATTACGCTCTGCTTTTCC \\
\hline CD90 & $\mathrm{S}$ & GACCCGTGAGACAAAGCAGC \\
\hline CD90 & AS & TGGCCAGAGTGGTGGAGT \\
\hline CD105 & $\mathrm{S}$ & TGCTCCTGATCCTCAGTGTG \\
\hline CD105 & AS & GCTCAGCAGCAGAGATGATG \\
\hline$\beta$-Actina & $\mathrm{S}$ & CTGGGGCCTAACGTTCTCAC \\
\hline$\beta$-Actina & AS & GTCCTTTCTTCCCCGATGTT \\
\hline
\end{tabular}

(Fonte: Iohara, K., et al. 2006)

Legenda: Oligonucleotídeos específicos de suínos utilizados na análise molecular por RT- PCR das células-tronco derivadas de polpa de dente canino e molar. TA: Temperatura de anelamento. Em todas as reações foram usadas a água como controle. 


\subsubsection{Caracterização funcional}

As células-tronco derivadas da polpa dentária de suínos (caninos e molares) foram submetidas à diferenciação em adipócitos, osteócitos e condrócitos.

\subsubsection{Diferenciações adipogênica e osteogênica}

Aproximadamente 40.000 células $/ \mathrm{mL}$ para diferenciação em adipócitos e 5.000 células $/ \mathrm{mL}$ (controle) foram cultivadas em placas de 24 poços sobre lamínulas. A diferenciação foi iniciada no mínimo 24 horas após o início do cultivo ou quando as células atingiam confluência em torno de $80 \%$. Nesta ocasião, todo o meio de cultura foi removido e, a seguir, foi adicionado $1 \mathrm{~mL}$ de meio de indução de adipócitos ou somente meio a-MEM (LGC) acrescido de 7,5\% de SFB (Invitrogen) no controle. As placas foram mantidas em estufa úmida a $37^{\circ} \mathrm{C}$ com $5 \%$ de $\mathrm{CO}_{2} \mathrm{e}$ metade do meio foi trocado 2 vezes por semana, até a diferenciação celular e monitoradas por microscopia invertida.

O meio utilizado para a indução da diferenciação em adipócitos foi o $\alpha-M E M$ suplementado com 15\% SBF, $10 \mu \mathrm{M}$ de dexametasona (Decadron injetável, Schering-Plough,SP, Brasil), $10 \mu \mathrm{g} / \mathrm{mL}$ de insulina (Sigma-Aldrich,) e $100 \mathrm{mM}$ de indometacina (Sigma-Aldrich) ou ainda, a-MEM suplementado com 15\% SBF, $10 \mu \mathrm{M}$ de dexametasona (Decadron), $10 \mu \mathrm{g} / \mathrm{mL}$ de insulina (Sigma-Aldrich, St. Louis, MO, EUA), $5 \mu \mathrm{M}$ de indometacina (Sigma-Aldrich) e $5 \mu \mathrm{M}$ de rosiglitazona (SigmaAldrich).

Além da microscopia de contraste de fase, ao final as células (controle e teste) foram submetidas a colorações para visualização do padrão de adipócitos.

As células diferenciadas em adipócitos e seus controles após aproximadamente 14 dias tiveram seu meio removido e foram lavadas com PBS. Após lavagens, as células foram fixadas em paraformaldeído $4 \%$ por 15 minutos à temperatura ambiente. Novamente as células foram lavadas com PBS 3 vezes, 
sendo então fixadas e novamente lavadas com álcool isopropílico a $60 \%$. Em seguida o corante oil red $(0,36 \%$ de oil red em álcool isopropilico a $60 \%)$ foi adicionado. Após $20 \mathrm{~min}$ de incubação a temperatura ambiente, o corante foi removido e as células foram lavadas com água destilada para remoção do excesso de corante. Em seguida, as lâminas foram montadas com glicerol e imediatamente analisadas em microscópio invertido Nikon Eclipse 80i uma vez que, o rompimento dos vacúolos após coloração é muito rápido.

\subsubsection{Diferenciação osteogênica}

Aproximadamente 40.000 células $/ \mathrm{mL}$ para diferenciação em osteócitos e 5.000 células $/ \mathrm{mL}$ (controle) foram cultivadas em placas de 24 poços. A diferenciação foi iniciada no mínimo 24 horas após o início do cultivo ou quando as células atingiam confluência em torno de $80 \%$. Nesta ocasião, todo o meio de cultura foi removido e, a seguir, foi adicionado $1 \mathrm{~mL}$ de meio de indução osteogênica ou somente o meio a-MEM (LGC) acrescido de 7,5 \% de SFB (Invitrogen) no controle. As placas foram mantidas em estufa úmida a $37^{\circ} \mathrm{C}$ com $5 \%$ de $\mathrm{CO}_{2}$ e metade do meio foi trocado 2 vezes por semana, até a diferenciação celular e monitoradas por microscopia invertida.

O meio utilizado para a indução da diferenciação em osteócitos foi composto por a-MEM 7,5\% SBF suplementado com 0,1 $\mu \mathrm{M}$ de dexametasona (Decadron injetável), $100 \mu \mathrm{M}$ de ácido ascórbico (Sigma-Aldrich) e $10 \mathrm{mM}$ de $\beta$-glicerolfosfato (Sigma-Aldrich).

Além da microscopia de contraste de fase, ao fina, as células (controle e teste) foram submetidas a coloração para o padrão esperado do tecido.

As células diferenciadas em osteócitos foram fixadas após 21 dias em paraformaldeído $4 \%$ por 20 minutos em temperatura ambiente, lavadas com PBS para remoção do excesso de paraformaldeído e coradas com $40 \mathrm{mM}$ de Alizarin Red $S$ em Tris pH 4,1 (Sigma). Passado 20 min da incubação, as células foram lavadas com água para a retirada do excesso de corante, essa lavagem ocorreu até não haver mais precipitado visível. Em seguida, as lâminas foram montadas com 
Permount (Fischer Scientific,) e levadas à análise em microscópio ótico (Nikon Eclipse 80i).

\subsection{ANÁLISE DO POTENCIAL CARCINOGÊNICO DAS CÉLULAS-TRONCO DERIVADAS DA POLPA DENTÁRIA DE SUÍNOS}

\subsubsection{Inoculação das células derivadas de dentes caninos e molares nos camundongos imunossuprimidos (nude)}

As células obtidas foram submetidas à avaliação do potencial carcinogênico em camundongos imunossuprimidos (nude). Para tanto, $1 \times 10^{6}$ células foram aplicadas via subcutânea na região de coluna cervical de 4 camundongos, sendo que dois animais receberam células derivadas de caninos e dois animais de molares. Primeiramente, as células foram lavadas, tripsinizadas e centrifugadas por 5 minutos a 1000 rpm com PBS para retirada dos resíduos de meio de cultivo. Em seguida, as células ressuspendidas foram novamente centrifugadas e o precipitado foi ressuspendido para contagem das células. Ao final, aproximadamente $1 \times 10^{6}$ células foram ressuspendidas em $30 \mu \mathrm{l}$ de PBS e aplicadas com auxilio de uma seringa de insulina.

\subsubsection{Avaliação macroscópica da formação tumoral}

A avaliação da ocorrência de formação tumoral foi realizada durante 60 dias e uma vez por semana verificou-se a formação tumoral.

Fotos macroscópicas da região cervical após inoculação das células-tronco derivadas de caninos e molares foram tiradas por máquina fotográfica Sony ${ }^{\circledR}$, Cyber Shot 7.2Mp. 
Após o prazo de 60 dias, os animais foram eutanasiados seguindo as recomendações do Comitê de Ética em pesquisa e os órgãos: coração, pulmão, rins, fígado e baço foram coletados e fixados para análises histopatológicas através da coloração de HE.

\subsubsection{Avaliação microscópica da formação tumoral}

Os órgãos destinados a análises histológicas foram fixados em solução formalina a $10 \%$ e as amostras foram submetidas aos protocolos rotineiros de inclusão em paraplast e coradas através das técnicas rotineiras de $\mathrm{HE}$ (WALLINGTON, 1972).

As fotomicrografias foram tiradas no microscópio Nikon Eclipse 80i. 


\section{RESULTADOS}

\subsection{CARACTERIZAÇÃO DOS TECIDOS DENTÁRIOS}

\subsubsection{Coloração Hematoxilina-Eosina}

A coloração de Hematoxilina e Eosina foi utilizada para a averiguação das estruturas que compõe a unidade dentária e, através desta coloração foi verificado que a unidade dentária é composta por diferentes tecidos, altamente especializados e mineralizados como o esmalte, cemento, dentina e a polpa ricamente inervada e vascularizada. Observe na figura $6 \mathrm{~A}$ e $\mathrm{B}$ dentina (setas amarelas), odontoblastos (seta azul) e fibroblasto (seta vermelha).

Além disso, foi possível visualizar diferenças estruturais na disposição do arranjo dos tecidos entre os caninos e molares, que lhes conferem resistências diferentes, visto que estes exercem funções distintas enquanto unidades dentárias (Figura 6).

Figura 6 - Fotomicrografia dos dentes através da coloração de Hematoxilina e Eosina
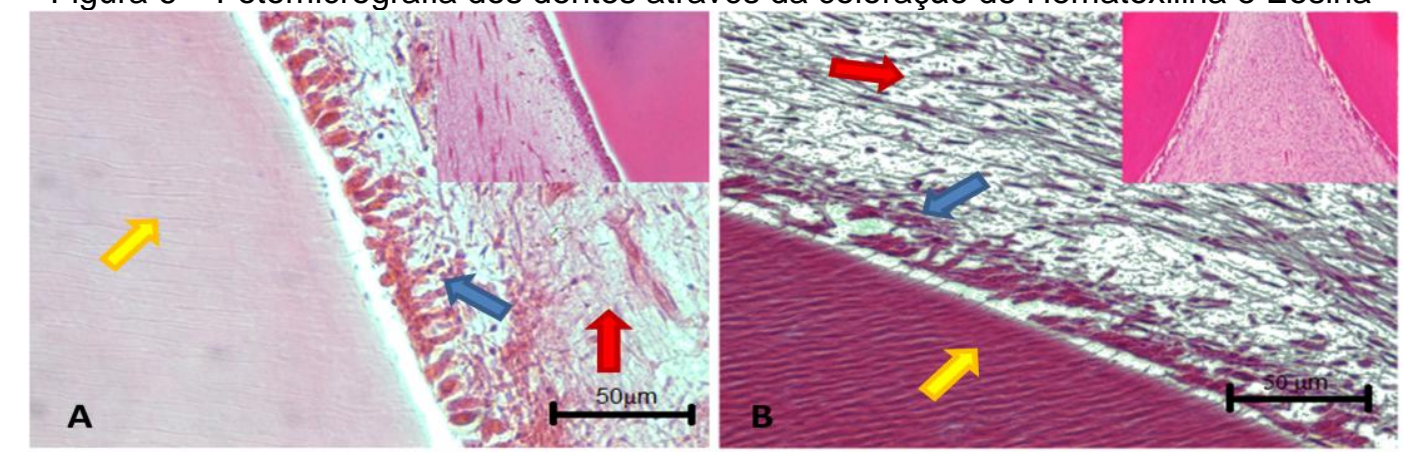

(Fonte: DIAS, J.L.R.M, 2012)

Legenda: A) canino; B) molar. Em aumento de 400X. Setas amarelas indicam a dentina; Seta azul, odontoblastos; Seta Vermelha: Fibroblastos dentina (seta amarela), odontoblastos (seta azul) e fibroblastos (seta vermelha). Acima e a direita em todas as figuras temos uma visão geral do tecido dentário no aumento de 100X. 


\subsubsection{Coloração Tricromo de Masson}

A coloração de Tricromo de Masson foi utilizada para a averiguação da presença de colágeno entre as estruturas que compõe o dente onde observamos que o dente possui em sua composição uma divisão bem estabelecida entre o material pulpar e a dentina, contudo prolongamentos nervosos são lançados da porção de odontoblastos (seta amarela - Figura 7) que se entremeiam através de micro túbulos localizados na região de cor predominantemente azul, onde está localizada a dentina (seta vermelha- Figura 7), e pudemos evidenciar a vascularização da camada pulpar (seta azul - Figura 7B).

Figura 7 - Fotomicrografia dos dentes através da coloração de Tricromo de Masson
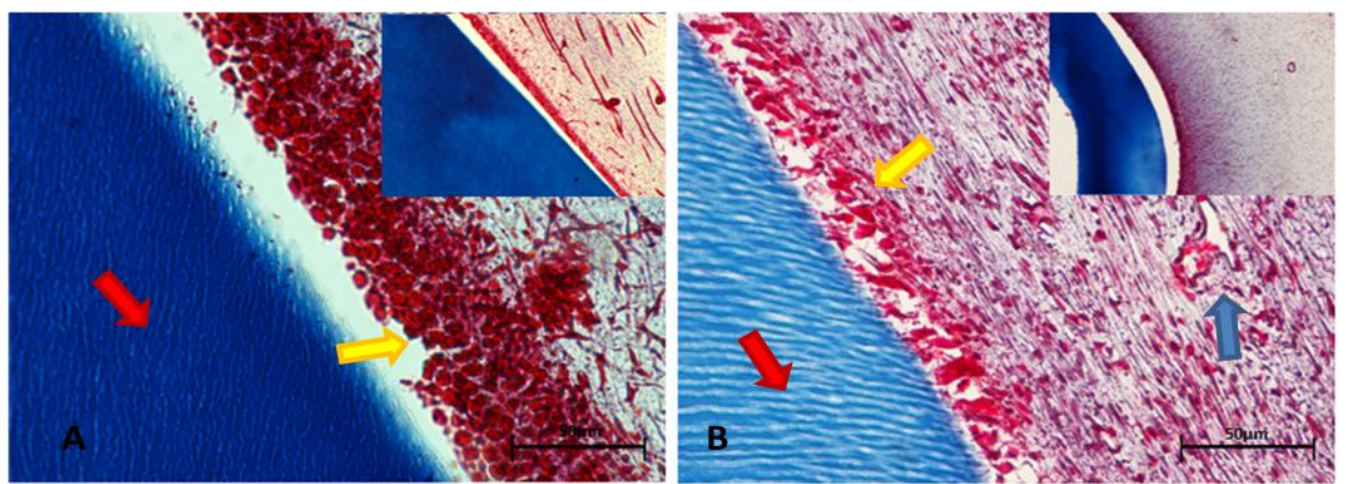

(Fonte: DIAS, J.L.R.M, 2012)

Legenda: A) canino e B) molar. Em todas as imagens temos aumento de 400X. Observe um pronunciamento sensivelmente maior na camada composta por odontoblastos nos caninos quando comparados aos molares (seta amarela), também foi possível visualizar a existência de vasos que promovem a irrigação do dente (seta azul), e a mudança para dentina (seta vermelha). Acima e a direita em todas as figuras temos uma visão geral do tecido dentário no aumento de $100 \mathrm{X}$. 


\subsubsection{Análise imunohistoquímica do tecido dentário}

Com a finalidade de caracterizar o tecido dentário quanto aos seus aspectos imunohistoquímicos, um painel de anticorpos foi estabelecido, contemplando antígenos pertinentes a CD73, CD105, CD34, CD45, Oct 3/4, Nanog, Sox-2, PCNA3, STRO-1 e Vimentina. Para controle negativo da reação, foi utilizado apenas o anticorpo secundário, sendo que esse, como esperado, não apresentou nenhuma marcação.

Para que as células derivadas de polpa dentária de caninos e molares pudessem ser classificadas como células-tronco mesenquimais, averiguou-se a expressão dos marcadores CD73, CD105 e não houve a expressão CD34 e CD45, como esperado. Observe na Figura 8, expressão de CD73 tanto nos dentes caninos (Figura 8A) como molares (Figura 8B) bem como, para o CD105 que apresentou uma marcação perinuclear muito mais evidente na amostra derivada de dente molar quando comparada a amostra derivada de dente canino (Figura 8C, dentes caninos e 8D, molares). Já não observamos a expressão de marcadores CD34 e CD45 nem para os dentes caninos e molares, respectivamente Figuras 8E, F, G e H. 
Figura 8 - Análise da expressão de marcadores de células-tronco mesenquimais nos dentes caninos e molares apresentando marcação positiva para CD73 e CD105 e, marcação negativa para CD34 e CD45

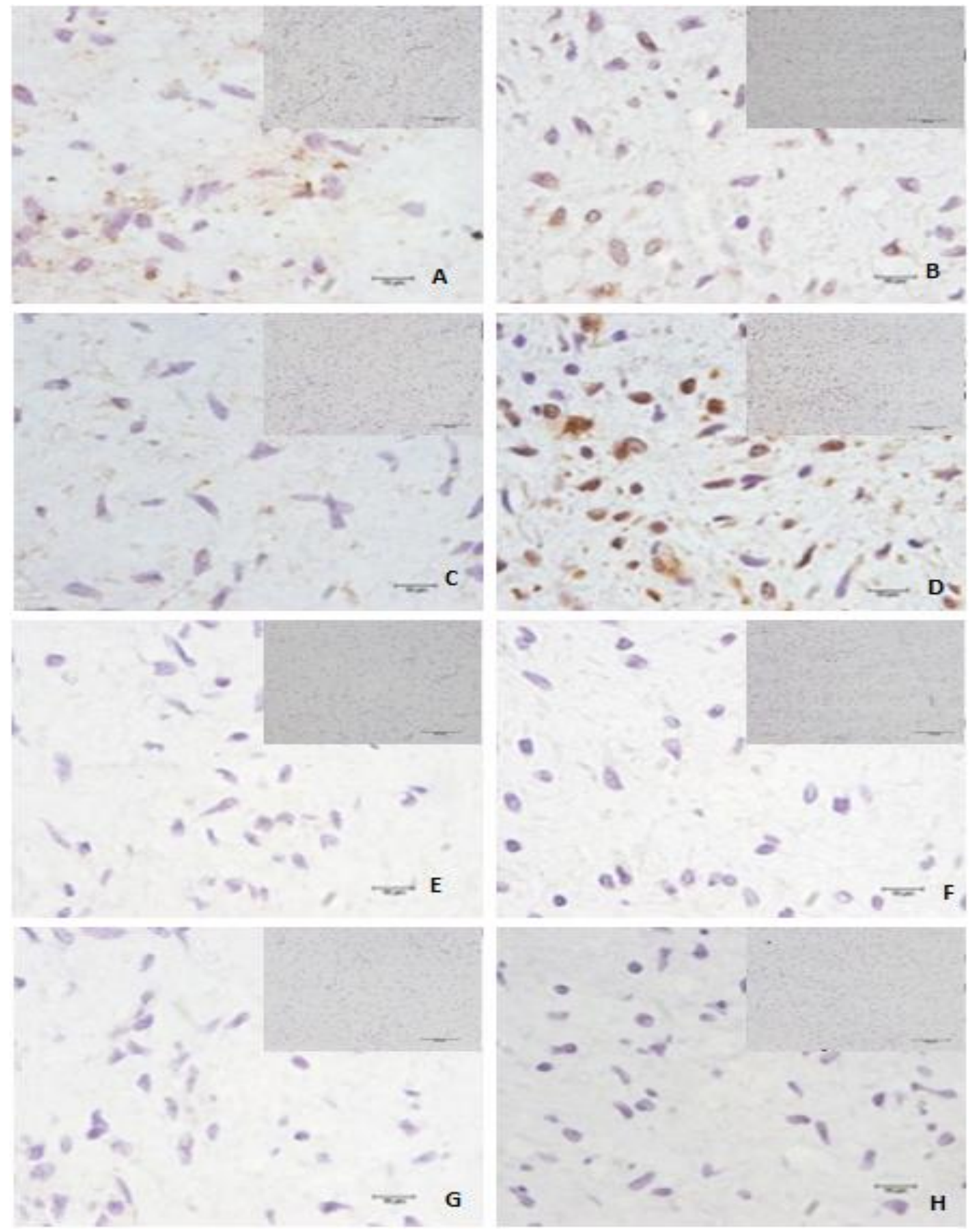

(Fonte: DIAS, J.L.R.M, 2012)

Legenda: A) canino e B) molar apresentando marcação positiva para CD73; C) canino e D) molar apresentando marcação positiva para CD105, contudo pôde-se evidenciar a marcação mais intensa desse marcador no material oriundo de dente molar quando comparado ao material derivado de dente canino; E) canino e F) molar apresentando marcação negativa para CD34; G) canino e H) molar apresentando marcação negativa para CD45. Em todas as imagens temos aumento de 400X. Acima e a direita em todas as figuras temos uma visão geral do tecido dentário no aumento de 100X. 
Com o intuito de verificar a presença de marcadores de pluripotência foram utilizados anticorpos anti-Oct-4, anti-Nanog e anti-Sox2 (Figura 9) e tanto caninos como molares apresentaram reações positivas para estes anticorpos mostrando que os mesmos eram expressos nestes tecidos, contudo é possível observar a marcação ligeiramente mais intensa para Oct-4 no tecido oriundo de canino quando comparado ao tecido derivado de molar (Figura 9A e B), ao passo que o inverso é verificado quando o anticorpo utilizado é o anti-Sox2 (Figura 9E e F).

Figura 9 - Fotomicrografias dos ensaios imunohistoquimicos dos tecidos dentários apresentando marcação positiva para Oct-4, Nanog e Sox2

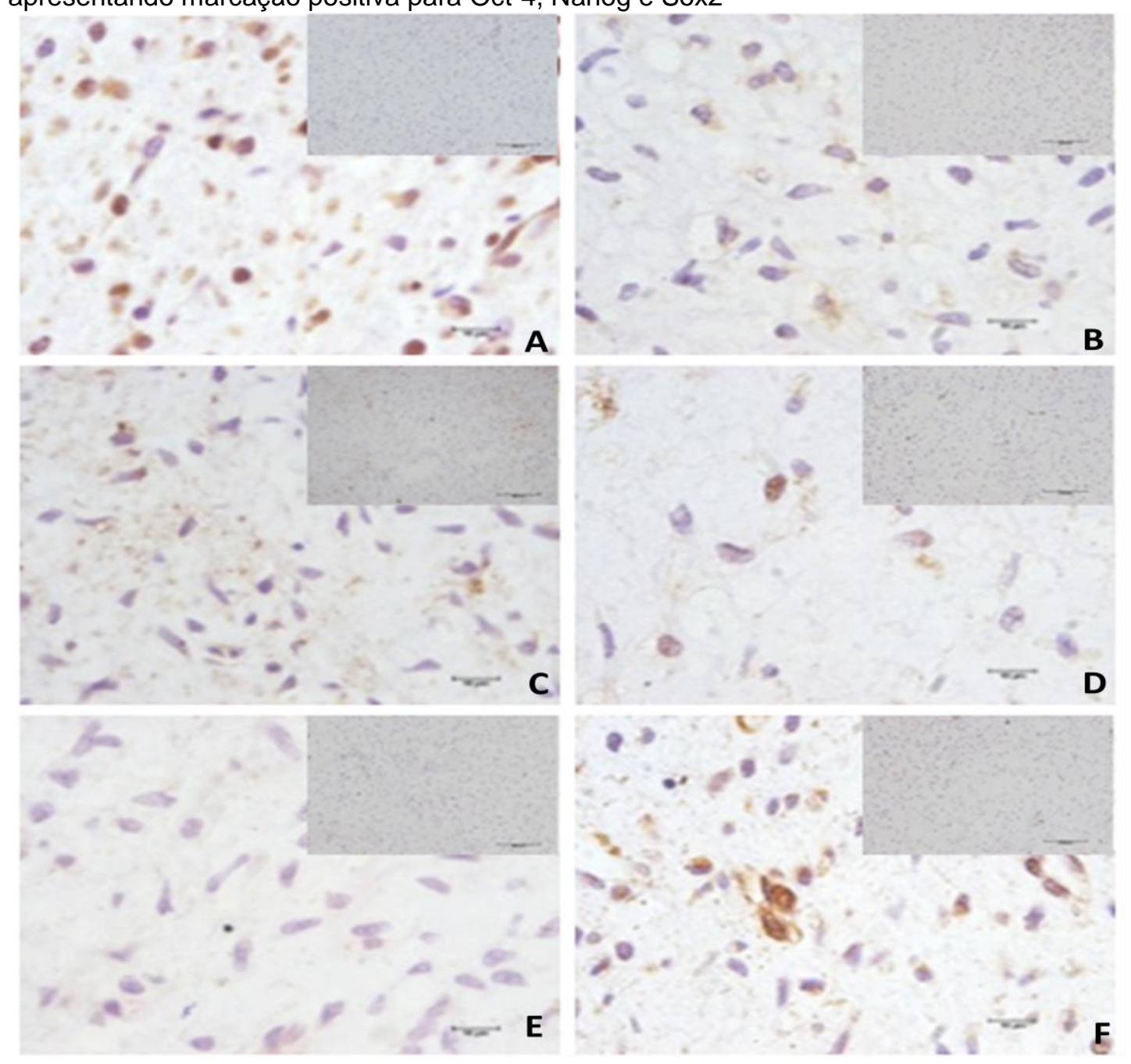

(Fonte: DIAS, J.L.R.M, 2012)

Legenda: A) canino e B) molar apresentando marcação positiva para Oct-4, contudo pôde-se evidenciar a marcação mais intensa desse marcador no material oriundo de dente canino; C) canino e D) molar apresentando marcação positiva para Nanog; E) canino e F) molar apresentando marcação positiva para Sox2, no que tange esse marcador, a marcação de maior intensidade apresentou-se no material oriundo de dente molar. Em todas as imagens temos o aumento de 400X. Acima e a direita em todas as figuras temos uma visão geral do tecido dentário no aumento de 100X. 
Com o intuito de avaliar a confiabilidade dos resultados, foram realizadas ensaios imunohistoquímicos em amostras derivadas de dentes caninos e molares, utilizando-se de anticorpo anti-PCNA3, marcador de ciclo celular e anticorpo antivimentina, marcador de citoesqueleto tanto os tecidos caninos e molares submetidos ao ensaio apresentaram a expressão destes marcadores como era esperado. Por fim,o controle negativo utilizando apenas o anticorpo secundário não apresentou marcação específica (Figura 10).

Figura 10 - Fotomicrografias dos ensaios imunohistoquímicos apresentando marcação positiva para PCNA3 e vimentina, e negativa para o controle.

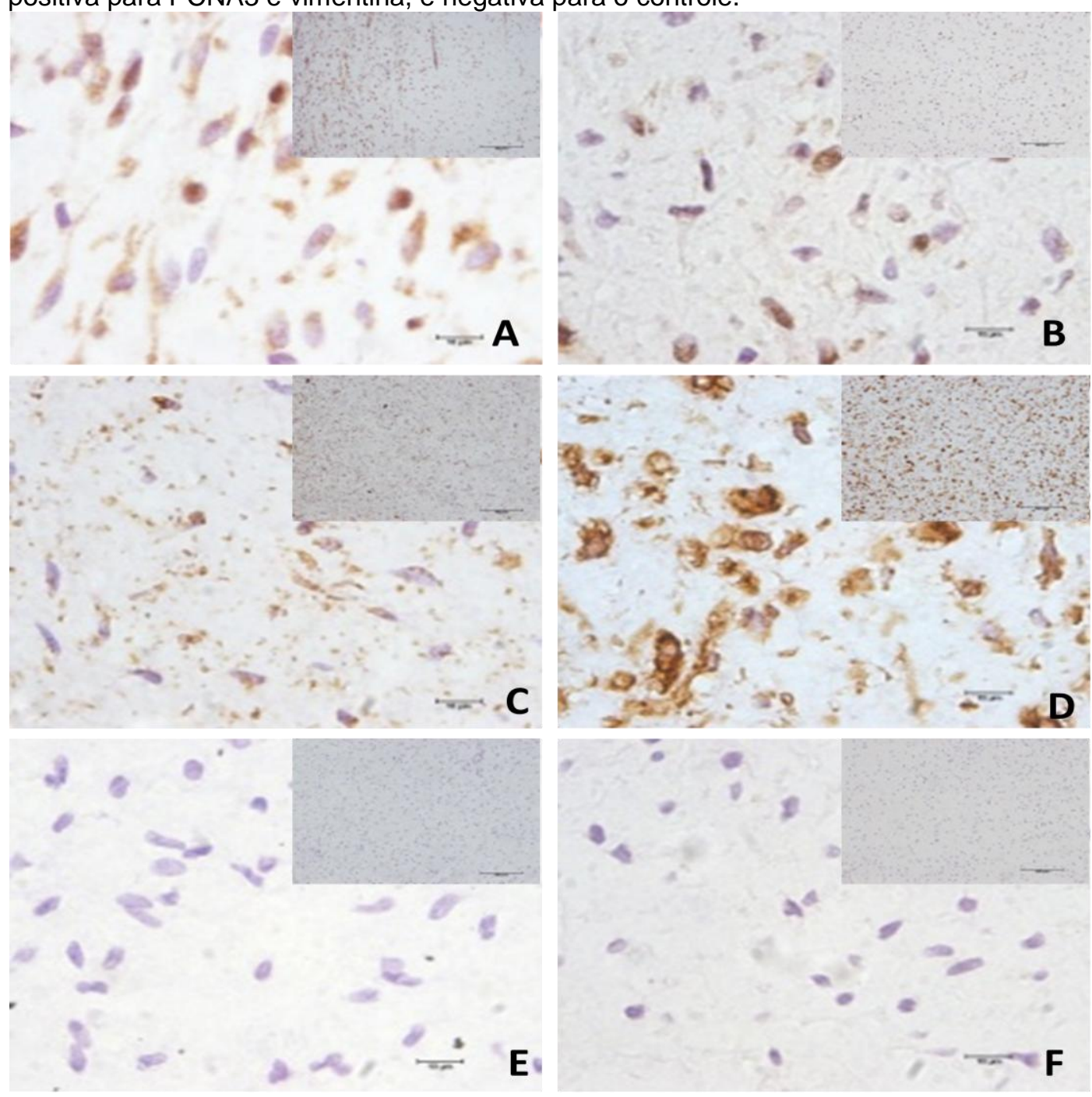

(Fonte: DIAS, J.L.R.M, 2012)

Legenda: A) canino e B) molar apresentando marcação positiva para PCNA3; C) canino e D) molar apresentando marcação positiva para vimentina; E) canino e F) molar apresentando marcação negativa como esperado, por se tratar de controle negativo. Em todas as imagens temos aumento de 400X. Acima e a direita em todas as figuras temos uma visão geral do tecido dentário no aumento de 100X. 


\subsubsection{ANÁLISE ESTRUTURAL DO DENTE POR MICROSCOPIA ELETRÔNICA DE VARREDURA}

Com a finalidade de avaliar estruturalmente a unidade dentária, bem como os diferentes tecidos que a compõe, foi realizado o protocolo de microscopia eletrônica de varredura. Devido a crio fratura, que é uma das etapas que antevêem à microscopia eletrônica de varredura propriamente dita, onde a ligação existente entre uma célula e outra realizada pelos desmossomos é rompida sem o emprego de lâmina ou instrumento cortante similar, as características da superfície do tecido são preservadas, e nas amostras oriundas de dentes caninos e molares pudemos observar a clara separação dos tecidos que dispostos em arranjos ordenados compõem uma unidade dentária.

A convergência existente na base dos dentes foi observada, onde o tecido pulpar, dentina e cemento, se estreitam até a formação do forame apical. Também pudemos observar a curvatura na região inferior ao colo dental que recebem os ligamentos periodontais, assim garantindo a fixação do mesmo, sendo que esta curvatura é bastante pronunciada nos dentes molares e muito mais discreta em dentes caninos (Figuras 11B e 12B - seta vermelha). Também pudemos observar a delimitação do tecido pulpar localizado no cerne de dente (Figuras 11A e 12A setas amarelas)

Nas fotomicrografias que contemplavam apenas a dentina, foi destacada a existência dos microtúbulos que conduzem prolongamentos da camada de odontoblastos (Figura 11C e 12C - seta azul) com extensões variadas, enquanto nas fotomicrografias que contemplava apenas o tecido pulpar, foi destacada a grande quantidade de vasos que possibilitam todo o aporte de nutrientes para todo o dente (Figuras 11D e 12D seta - verde). 
Figura 11 - Fotomicrografia da microscopia eletrônica de varredura realizada em dente canino
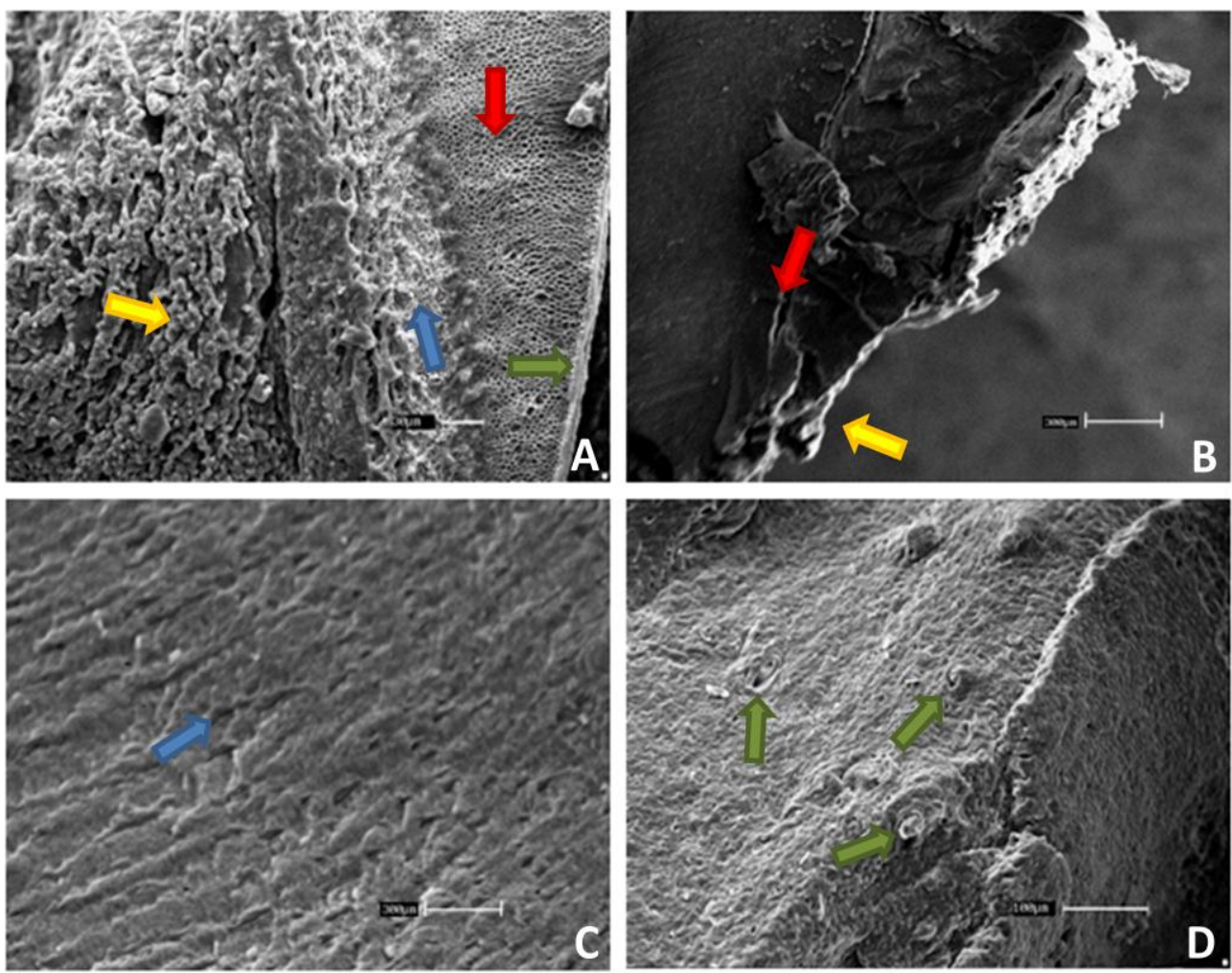

(Fonte: DIAS, J.L.R.M, 2012)

Legenda: A) divisão dos tecidos dentais, polpa (seta amarela), camada composta por odontoblastos (seta azul), cemento (seta vermelha) e esmalte (seta verde); B) Convergência dos tecidos na formação do forame apical (seta vermelha), curvatura na região inferior ao colo que receberá os ligamentos periodontais; C) fotomicrografia evidenciando a inúmera quantidade de microtúbulos existentes na dentina (seta azul); D) fotomicrografia evidenciando os vasos responsáveis pelo aporte de nutrientes (seta verde). 
Figura 12 - Fotomicrografia da microscopia eletrônica de varredura realizada em dente molar
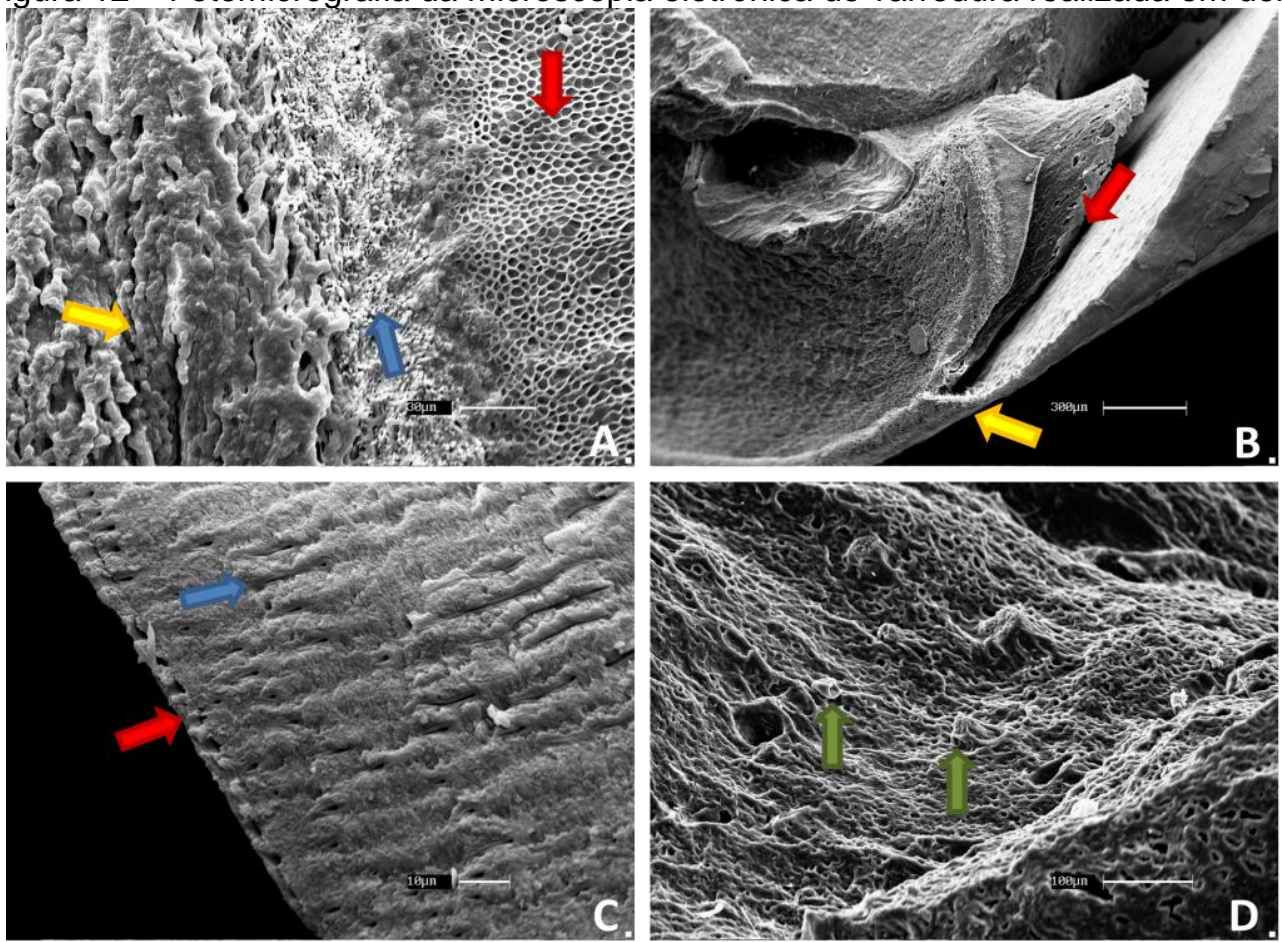

(Fonte: DIAS, J.L.R.M.,2012)

Legenda: A) divisão dos tecidos dentais, polpa (seta amarela), camada composta por odontoblastos (seta azul) e cemento (seta vermelha); B) Convergência dos tecidos na formação do forame apical (seta vermelha), curvatura na região inferior ao colo que receberá os ligamentos periodontais; C) fotomicrografia evidenciando a inúmera quantidade de microtúbulos existentes na dentina (seta azul) e esmalte realizando o revestimento do dente (seta verde); D) fotomicrografia evidenciando os vasos responsáveis pelo aporte de nutrientes (seta verde). 


\subsection{CULTIVO DE CÉLULAS-TRONCO DE POLPA DENTÁRIA DE SUÍNOS}

Como relatado em materiais e métodos, dois tipos de técnicas foram utilizadas para os cultivos das células-tronco da polpa dentária de dentes caninos e molares de suínos, a técnica de explante e a digestão enzimática com colagenase I e os resultados obtidos estão descritos abaixo.

\subsubsection{Cultivo das células-tronco de polpa dentária de suínos processadas por explante}

$\mathrm{Na}$ primeira tentativa de estabelecer a cultura de células-tronco derivadas da polpa de dentes de suínos, foi realizada a técnica de explante, onde a amostra foi acompanhada e fotografada por aproximadamente 60 dias. Durante esse período, não foi percebida nenhum desprendimento celular a partir do tecido bem como, adesão do tecido ao plástico e crescimento celular, culminando com a morte do mesmo próximo ao segundo mês de experimento.

Uma segunda tentativa da realização da técnica de explante foi realizada, contudo, os resultados obtidos foram os mesmos da tentativa anterior, não se alcançando o sucesso para o estabelecimento do cultivo (Figura 13). 
Figura 13 - Fotomicrografia da tentativa do estabelecimento da cultura celular pela técnica de explante
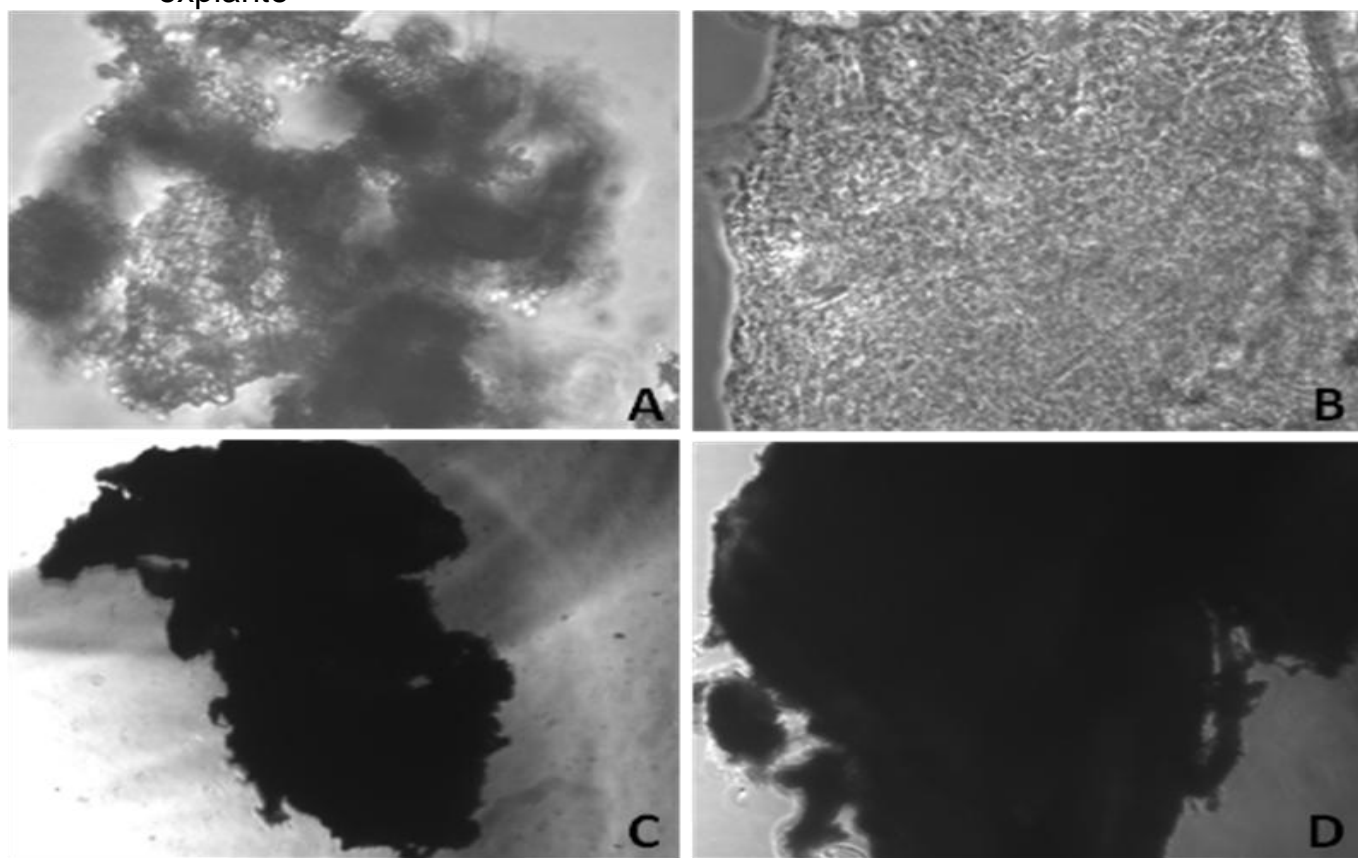

(Fonte: DIAS, J.L.R.M., 2012)

Legenda: A) Tecido canino após fragmentação, no dia da realização da cultura através da técnica de explante; B) cultura aparentemente viável; C) Tecido dentário canino após aproximadamente 60 dias de cultivo; D) Tecido dentário canino opaco e aparentemente morto. A,C) Aumento de 40x; B, D) 100x 


\subsubsection{Cultivo das células-tronco de polpa dentária de suínos digestão enzimática usando Colagenase I}

Uma vez que não foi alcançado o sucesso do estabelecimento da cultura de células-tronco de polpa dentária de suíno por explante, a técnica de digestão enzimática utilizando colagenase do tipo I foi realizada e após poucas horas da digestão já foi possível observar células refringentes aderidas ao plástico tanto para as polpas dentárias de caninos como de molares, respectivamente (Figura 14A e B).

Figura 14 - Fotomicrografia das células-tronco das polpas dentárias de dentes caninos e molares poucas horas após a digestão enzimática com Colagenase tipo I.
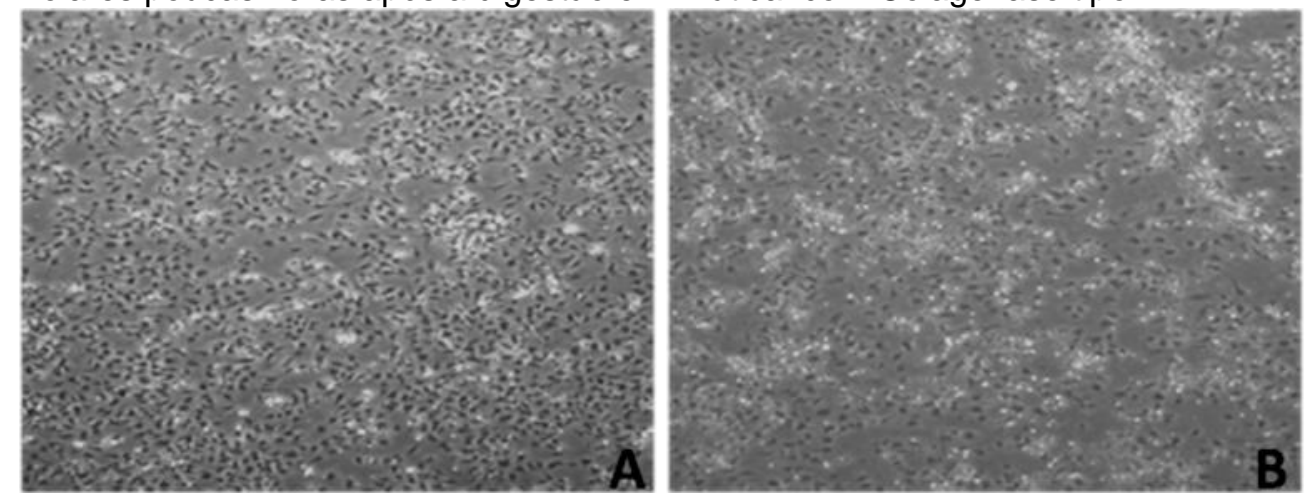

(Fonte: DIAS, J.L.R.M., 2012)

Legenda: A) canino e B) molar, no dia da cultura; aumento de 40X; 
Após 96 horas contadas à partir do início da cultura, realizou-se o primeiro processo de amplificação das amostras, uma vez que este se fez necessário, dada a alta confluência celular alcançada pelas amostras de caninos e molares durante esse período (Figura 15).

Figura 15 - Fotomicrografia das células-tronco de polpa dentária de caninos e molares com $96 \mathrm{~h}$ da obtenção e após tripsinização

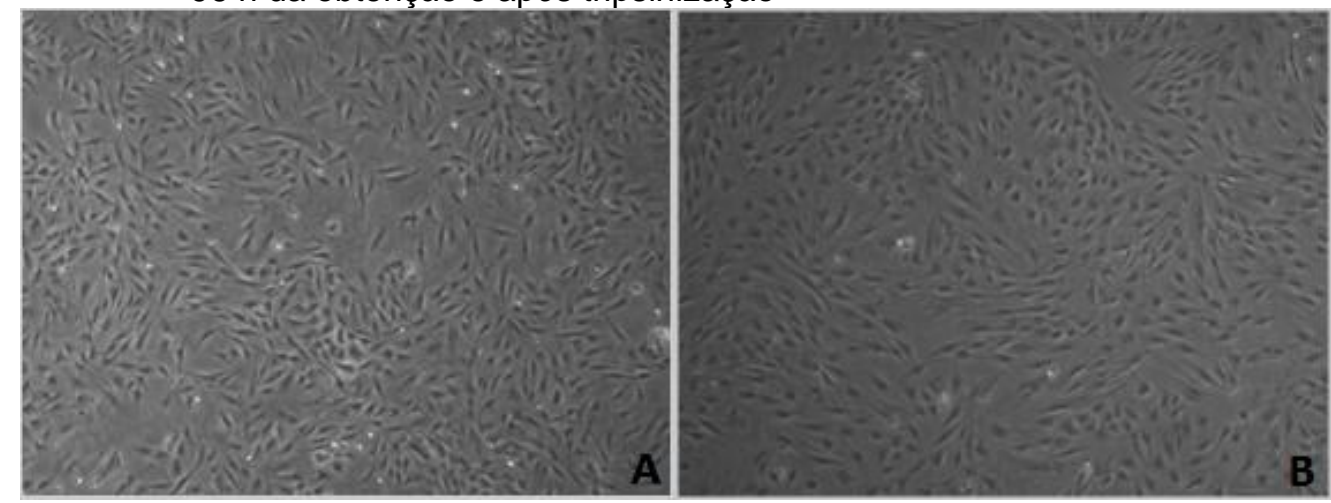

(Fonte: DIAS, J.L.R.M., 2012)

Legenda: A) canino e B) molar após tripsinização, aumento de 100X;

Novas amplificações foram realizadas para a execução dos experimentos que se seguiram, e devido ao sucesso alcançado na digestão enzimática com colagenase I, ela foi adotada como padrão para a obtenção das culturas de célulastronco derivadas de dentes caninos e molares. 


\subsection{ANÁLISE DE CRIOPRESERVAÇÃO DAS CÉLULAS-TRONCO DE POLPA DENTÁRIA DE SUÍNOS}

Com a finalidade de avaliar a viabilidade das células-tronco de polpa dentária de dentes caninos e molares de suínos as células foram congeladas e após 45 descongeladas onde pudemos observar ambos os grupos celulares foram suscetíveis ao congelamento uma vez que estas se apresentavam sem alterações morfológicas (Figura 16).

Figura 16 - Fotomicrografia das células-tronco derivadas de polpa dentária de caninos e molares após 45 dias de congelamento
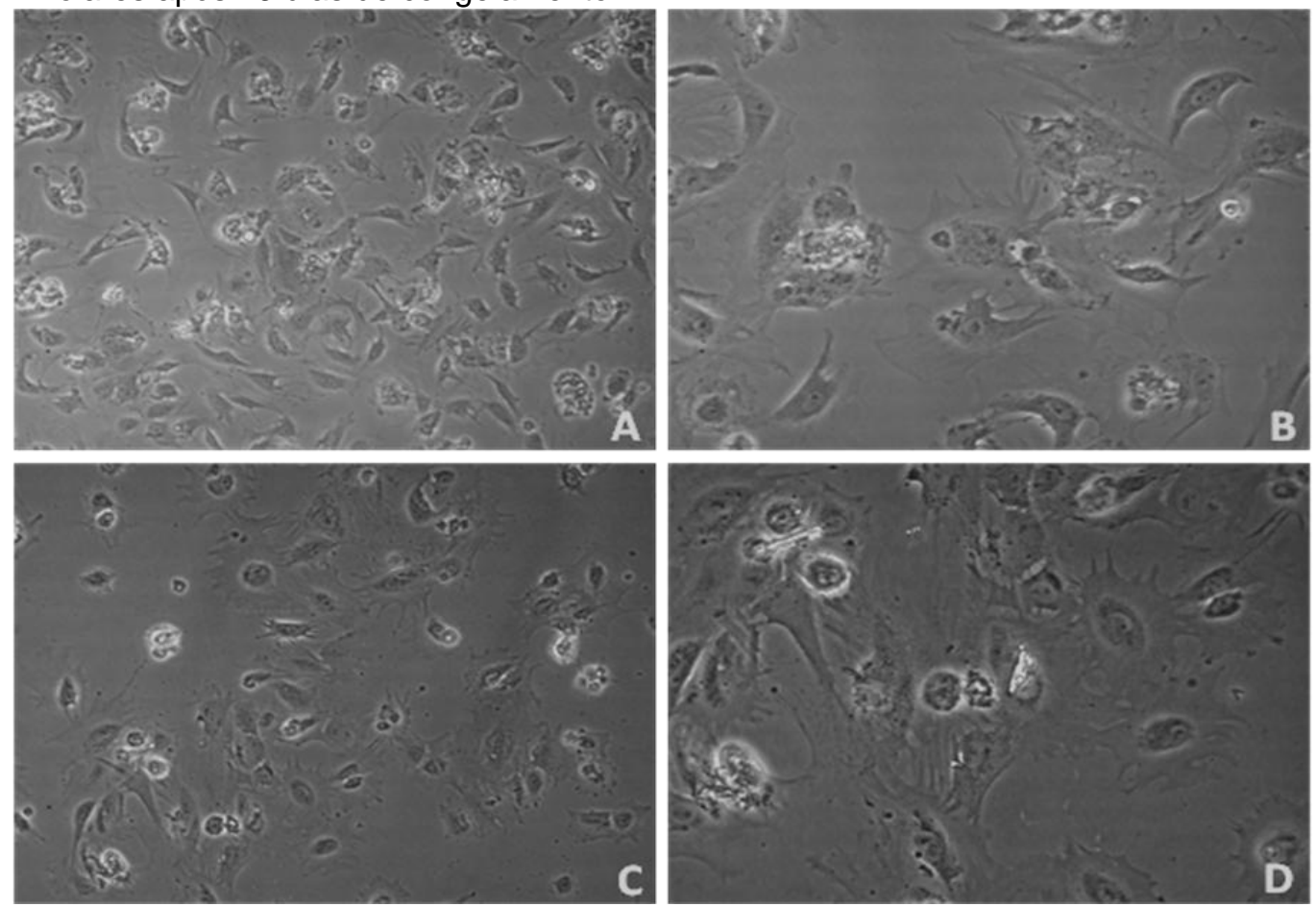

(Fonte: DIAS, J.L.R.M., 2012 )

Legenda: A, B) canino 45 dias após congelamento; C; D) molar também mostrando sua viabilidade após criopreservação. A) e B) Aumento de 100x; C) e D) aumento de 200x 


\subsection{CARACRETIZAÇÃO BIOLÓGICA DAS CÉLULAS-TRONCO DE POLPA DENTÁRIA DE SUÍNOS}

\subsubsection{Caracterização morfológica}

Durante o período de cultivo, as amostras foram monitoradas e fotografadas sistematicamente. A morfologia fibroblastóide bastante semelhante à das CTM foi observada nas células derivadas de polpa dentária de caninos e molares (Figura 17).

Figura 17 - Fotomicrografia das culturas derivadas de dentes caninos e molares
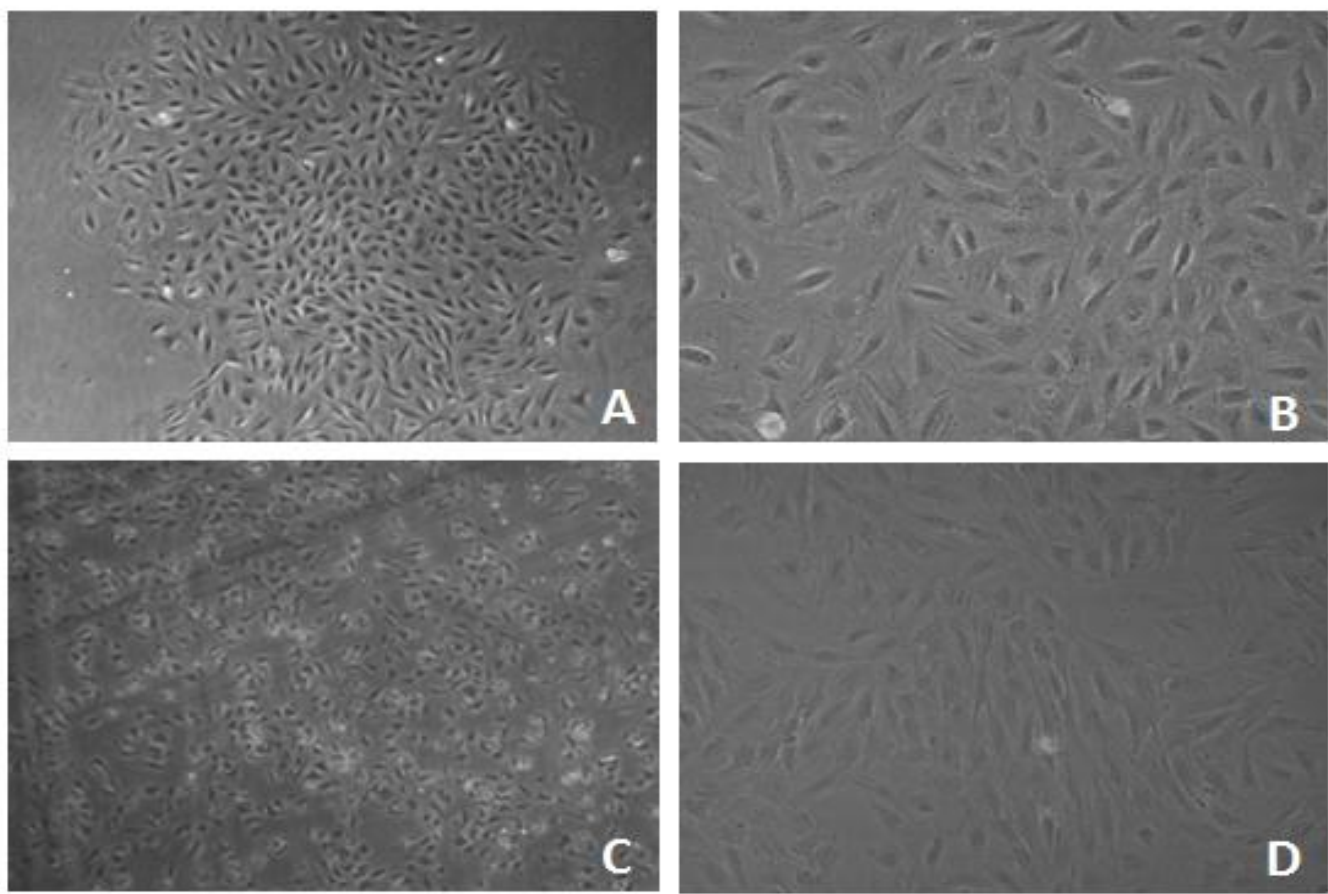

(Fonte: DIAS J.L.R.M, 2012)

Legenda: $A, B)$ Células-tronco derivadas de polpa dentárias de caninos; $C$;D) molares Em A,C) Aumento de 100x; B,D) 200x 


\subsubsection{Análise morfológica das células-tronco de polpa dentária de suínos por coloração de Hematoxilina e Eosina}

Com a finalidade de caracterizar morfologicamente as células-tronco de polpa dentária de caninos e molares suínos, foi realizado o protocolo de coloração por HE, onde este possibilitou a visualização de núcleos bem delimitados, cromatina fina e homogeneamente granulada e a presença de discretos nucléolos (seta amarela Figura 18) alocados em núcleos arredondados (seta azul- Figura18) também foi possível observar um padrão regular quanto a morfologia das amostras derivadas de caninos e de molares (Figura 18).

Figura 18 - Fotomicrografia realizada após a coloração por Hematoxilina e Eosina.

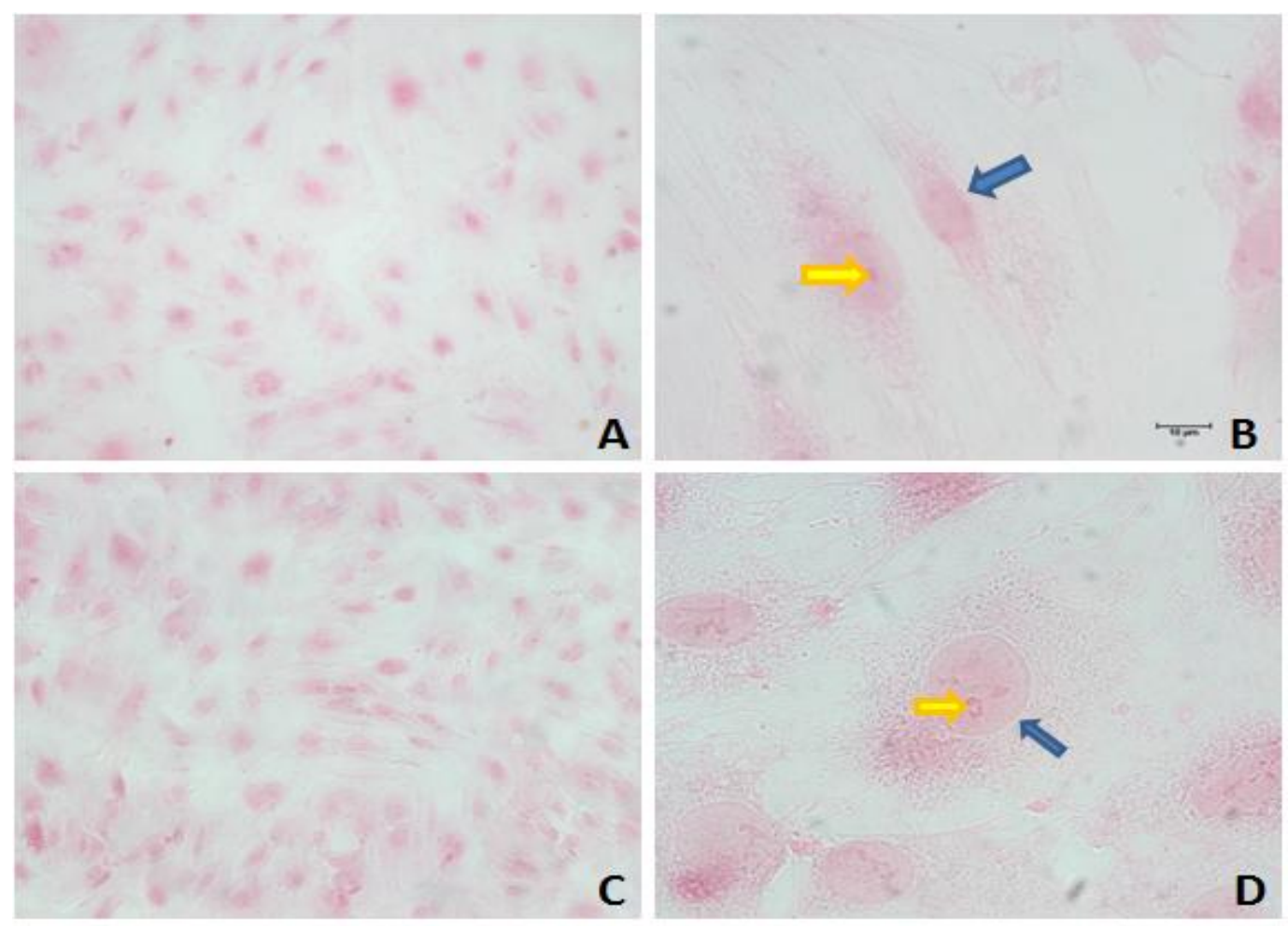

(Fonte: DIAS J.L.R.M, 2012)

Legenda: A,B) canino; C,D) molar . Em A,C) Aumento de 200x, B,D) 1000x 


\subsubsection{Análise morfológica das células-tronco de polpa dentária de suínos por coloração de Azul de Toluidina}

Ainda com o intuito de completar a caracterização morfológica das célulastronco derivadas da polpa dentária de caninos e molares suínos, realizou-se a coloração por Azul de Toluidina, um corante catiônico, que apresenta tropismo por estruturas básicas, especialmente citoplasmáticas.

Através desta técnica pôde-se avaliar com mais clareza a morfologia fibroblastóide existente nas amostras, sendo que essa foi averiguada através dos prolongamentos que se lançam de cada célula, compondo assim um padrão característico de células-tronco mesenquimal (Figura 19).

Figura 19 - Fotomicrografia das células-tronco de polpa dentária de dentes caninos e molares suínos coradas por Azul de Toluidina

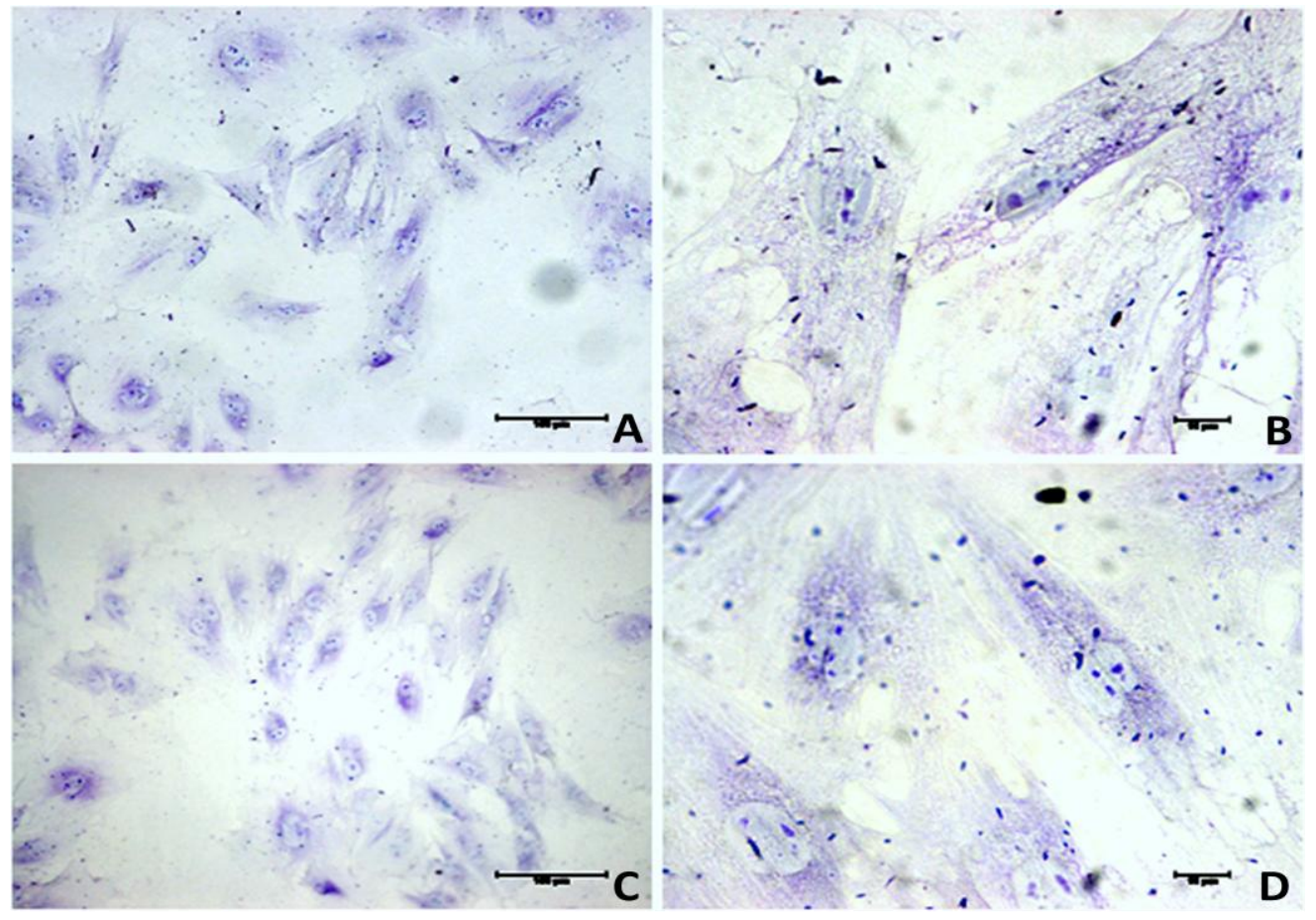

(Fonte: DIAS, J.L.R.M, 2012 )

Legenda: $A, B)$ Células-tronco derivadas de polpa dentária de dentes caninos $C, D$ ) molar Observe o padrão fibroblastóide destas células que é o mesmo existente nas células-tronco mesenquimais. A,C) Aumento de 200X e B,D) aumento de 1000X. 


\subsection{CARACTERIZAÇÃO CELULAR}

\subsubsection{Ensaio de proliferação celular pelo método colorimétrico de MTT}

Com o intuito de avaliar o perfil de crescimento celular das células-tronco derivadas de polpa dentária de caninos e molares, as mesmas foram submetidas ao ensaio colorimétrico de MTT, utilizando quantidades diferentes celulares $\left(1 \times 10^{3} \mathrm{e}\right.$ $5 \times 10^{3}$ ), com o objetivo de observar se o comportamento delas variava de acordo com o aumento do número de células.

Após 9 dias de experimento, os resultados obtidos foram plotados em gráficos e então pôde-se observar um padrão de crescimento constante e exponencial para os dentes caninos utilizando quantidade diferentes de células (Gráfico 1A e B). O mesmo comportamento foi observado nas células-tronco de polpa dentária de dentes molares utilizando $1 \times 10^{3}$ células (Gráfico 2A). Já, quando foram utilizadas $5 \times 10^{3}$ células observamos durante a segunda leitura um ligeiro declínio, que depois segue o padrão de crescimento apresentado pelas demais amostras (Gráfico 2B). 
Gráfico 1 - Análise da proliferação das células-tronco de polpa dentária de dentes caninos pelo método colorimétrico de MTT

A

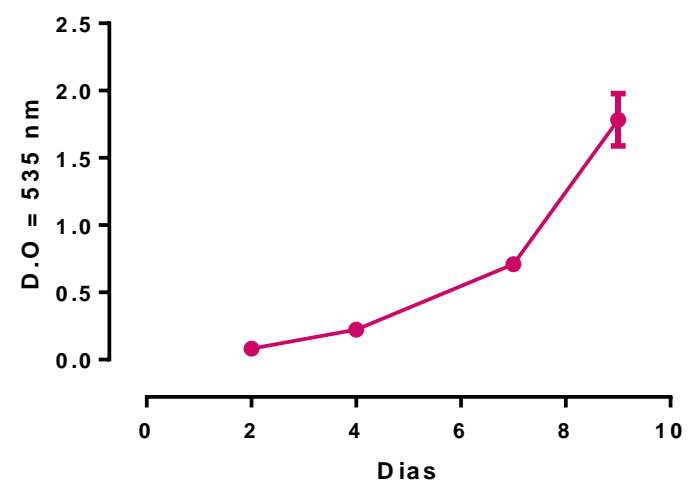

B

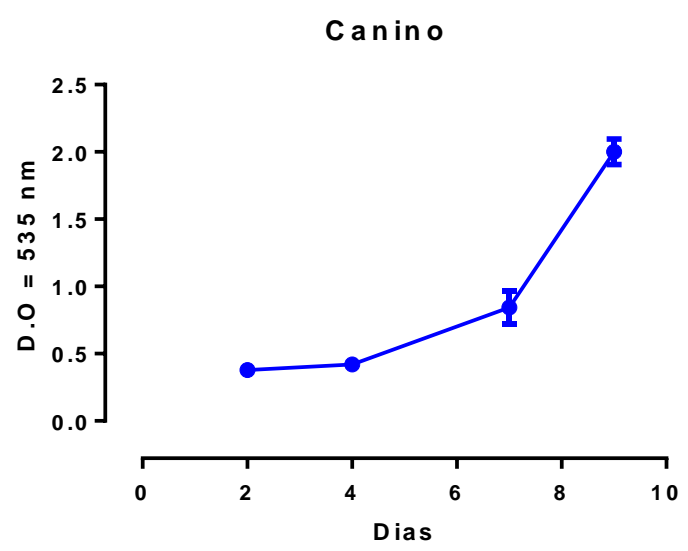

(Fonte: DIAS, J.L.R.M, 2012)

Legenda: Aproximadamente 1 ou $5 \times 10^{3}$ células-tronco de polpa dentária de dentes caninos foram plaqueadas e submetidas ao teste colorimétrico durante 11 dias e os resultados obtidos plotados no Programa GraphPad Prism. A) $1 \times 10^{3}$ células, B) $5 \times 10^{3}$ células

Gráfico 2 - Análise da proliferação das células-tronco de polpa dentaria de dentes molares pelo método colorimétrico de MTT

A

Mola r

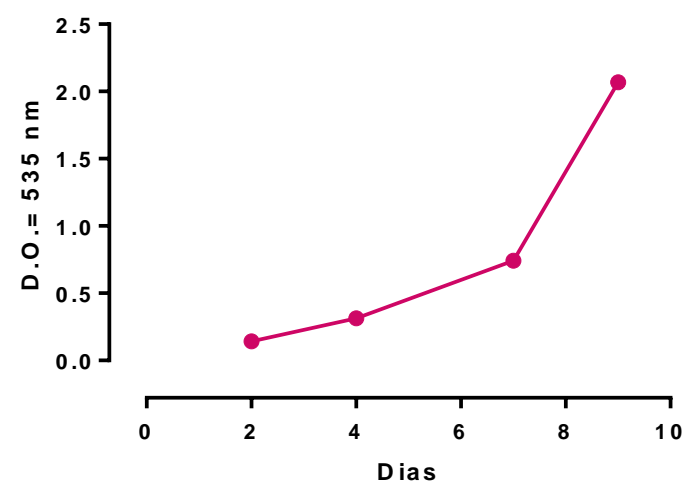

B

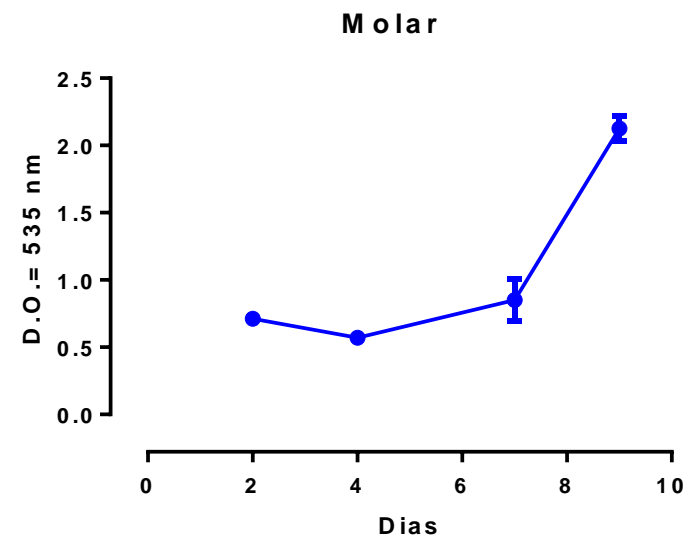

(Fonte: DIAS, J.L.R.M, 2012)

Legenda: Aproximadamente 1 ou $5 \times 10^{3}$ células-tronco de polpa dentária de dentes molares foram plaqueadas e submetidas ao teste colorimétrico durante 11 dias e os resultados obtidos plotados no Programa GraphPad Prism.A) $1 \times 10^{3}$ células, B) $5 \times 10^{3}$ células 


\subsubsection{Análise Imunocitoquímica das Células-Tronco derivadas de polpa dentária de dentes caninos e molares}

As análises imunocitoquímicas utilizando um painel de anticorpos foram realizadas e revelaram que as células derivadas de polpa dentária de caninos e molares expressaram CD73 e CD105, como era esperado (Figuras 20 e 21A e B).

Figura 20 - Análise do perfil de expressão de CD73 e CD105 nas células-tronco derivadas de dentes caninos
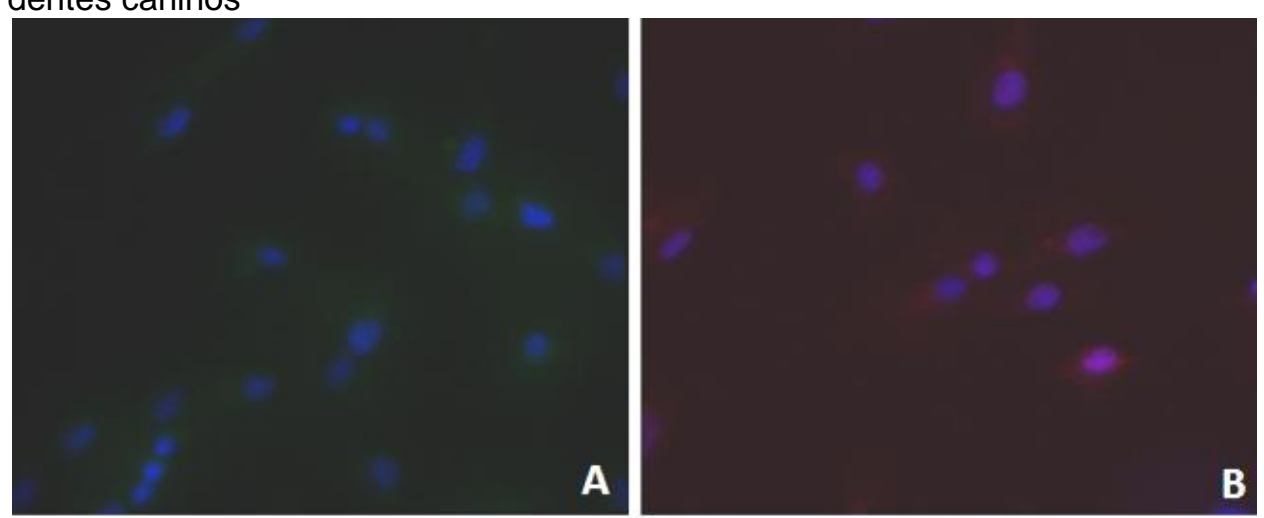

(Fonte: DIAS, J.L.R.M., 2012)

Legenda: Células-tronco de polpa dentária de dentes caninos foram fixadas em paraformaldeído a $4 \%$, bloqueadas em PBS contendo $2 \%$ de BSA e os anticorpos anti- CD73, anti-CD105 foram adicionados. A imunoreatividade foi revelada pelo anticorpo ligado ao (A) FITC e Texas Red (B), os núcleos foram corados com DAPI, e as respectivas sobreposições foram montados, e exibidos em aumento de 400X. A) CD73 e B) CD105.

Figura 21 - Análise do perfil de expressão de CD73, CD105 nas células-tronco derivadas de dentes molares de suínos
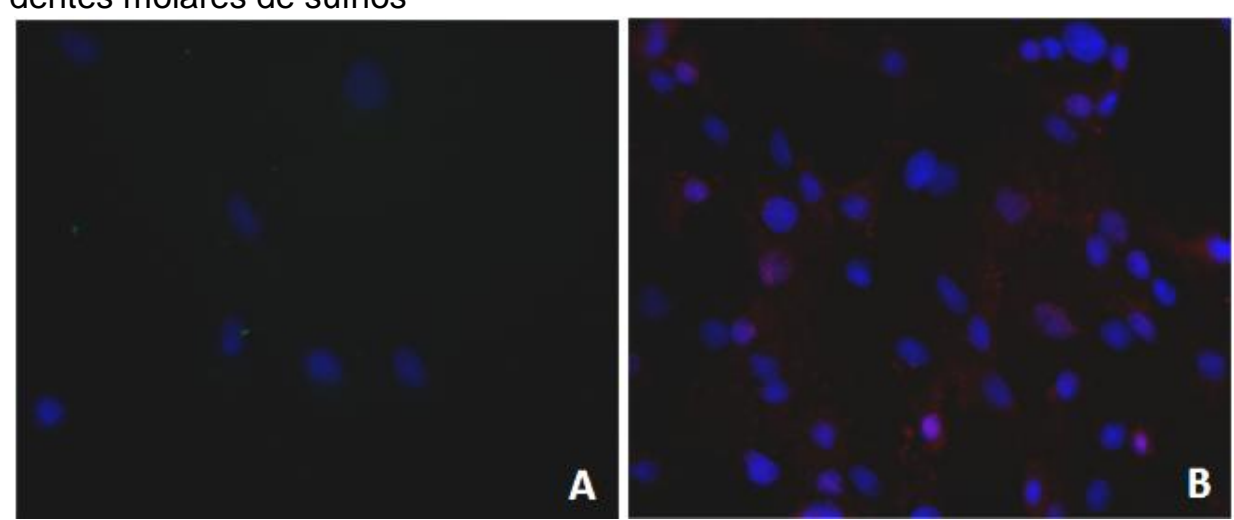

(Fonte: DIAS,J.L.R.M, 2012)

Legenda: Células-tronco de polpa dentária de dentes molares foram fixadas em paraformaldeído a $4 \%$, bloqueadas em PBS contendo $2 \%$ de BSA e os anticorpos antiCD105, anti-CD73, foram adicionados. A imunoreatividade foi revelada pelo anticorpo ligado ao (A) FITC e Texas Red (B), os núcleos foram corado com DAPI, e as respectivas sobreposições foram montados, e exibidos em aumento de 400X. A) CD73 e B) CD105. 


\subsection{CARACTERIZAÇÃO MOLECULAR DAS CÉLULAS-TRONCO DE POLPA DENTÁRIA DE SUÍNOS ATRAVÉS DE RT-PC}

A análise molecular das células-tronco da polpa dentária de suíno (dentes caninos e molares) foi realizada através de RT-PCR utilizando a mesma quantidade de RNA $(1 \mu \mathrm{g})$ para cada amostra, com o objetivo de analisar de forma comparativa a expressão dos genes suínos Sox2, CD34, CD45, CD90, CD105 e $\beta$-actina.

A figura 22 representa os resultados obtidos com as células do dente canino onde há expressão do gene $\beta$-actina, com a visualização de um fragmento de aproximadamente 198 pb na linha 7, como esperado já que é uma proteína com importantes funções celulares e que foi utilizada como controle positivo da reação. Ainda nesta figura podemos observar na linha 5 mais fracamente o fragmento com aproximadamente 171 pb para o CD90 e na linha 6 observamos um fragmento com aproximadamente 204pb para CD105 como era esperado, já que são marcadores de células-tronco mesenquimais. Na linha 2 não houve expressão de e nas linhas 3 e 4 observamos um fraco fragmento para CD34 com 184pb e CD45 com 191pb, esses fragmentos não eram esperados, pois, são genes expressos em células hematopoiéticas. 
Figura 22 - Análise molecular por RT-PCR das células-tronco de polpa dentaria de dentes caninos de suínos

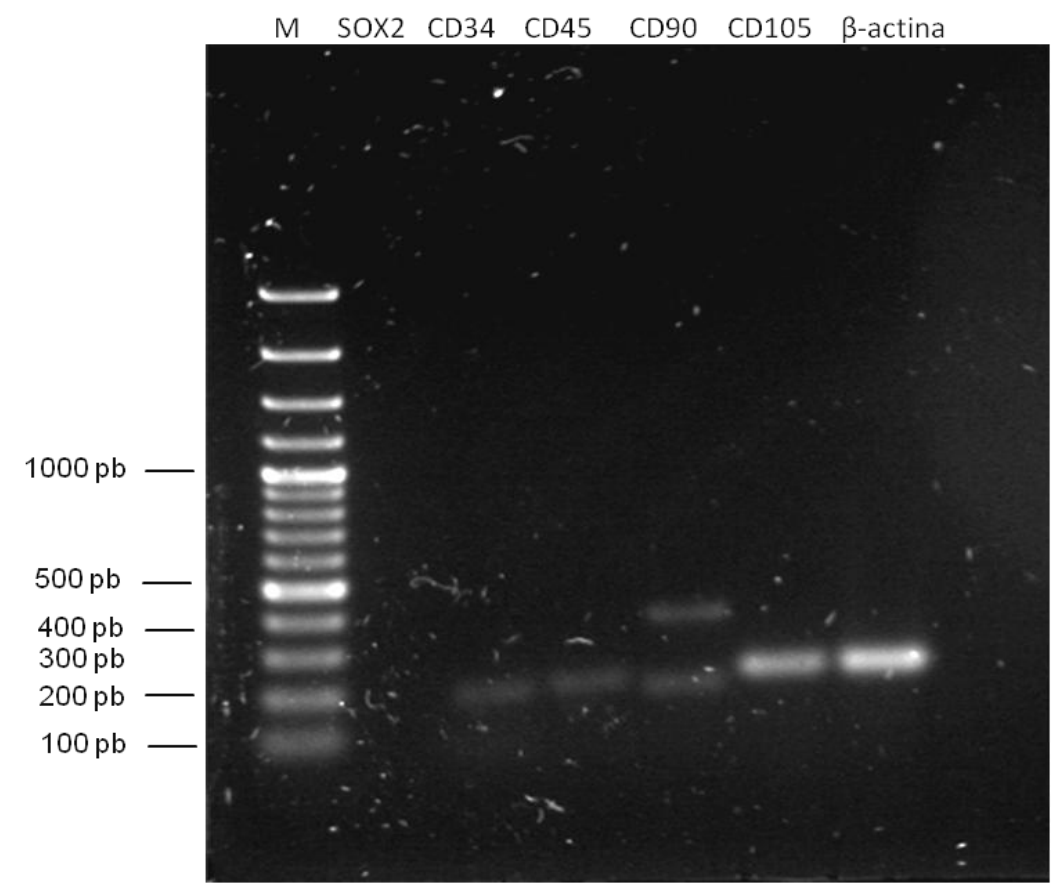

(Fonte: DIAS, J.L.R.M., 2012)

Legenda: O cDNA obtido a partir do RNA foi utilizado como fita molde. Oligonucleotídeos utilizados anelam nos genes SOX2, CD34, CD45, CD90, CD105 e $\beta$ Actina (controle). O produto obtido na RT-PCR foi submetido à corrida eletroforética em gel de agarose $1,5 \%$, sob tensão de $100 \mathrm{~V} / \mathrm{cm} 2$ e corados com SYBR SAFE DNA STAIN antes de ser fotografado pelo sistema Image Quant VDS. Linha 1, Marcador de peso molecular DNA ladder de 100 pb; Linha 2) SOX2 (203 pb); Linha 3: CD34 (184pb); Linha 4) CD45 (191pb); Linha 5) CD90 (171pb); Linha 6) CD105 (204pb); Linha 7) $\beta$-actina (198 pb).

A figura 23 representa os resultados obtidos com as células-troncos derivadas dos dentes molares de suínos onde há expressão do gene $\beta$-actina, com a visualização de um fragmento de aproximadamente 198 pb na linha 7, como esperado. Ainda nesta figura pudemos observar na linha 5 mais fracamente fragmentos com aproximadamente $171 \mathrm{pb}$ para CD90 e na linha 6 fragmento com aproximadamente 204pb para CD105 como era esperado, já que são genes expressos em células-tronco mesenquimais. Na linha 2 não houve expressão de Sox2 como era esperado já que é marcador de pluripotência e nas linhas 3 e 4 também não observamos fragmentos para CD34 e CD45 como era esperado já que são genes expressos em células hematopoiéticas. 
Figura 23 - Análise molecular por RT-PCR das células-tronco de polpa dentaria de dentes molares de suínos

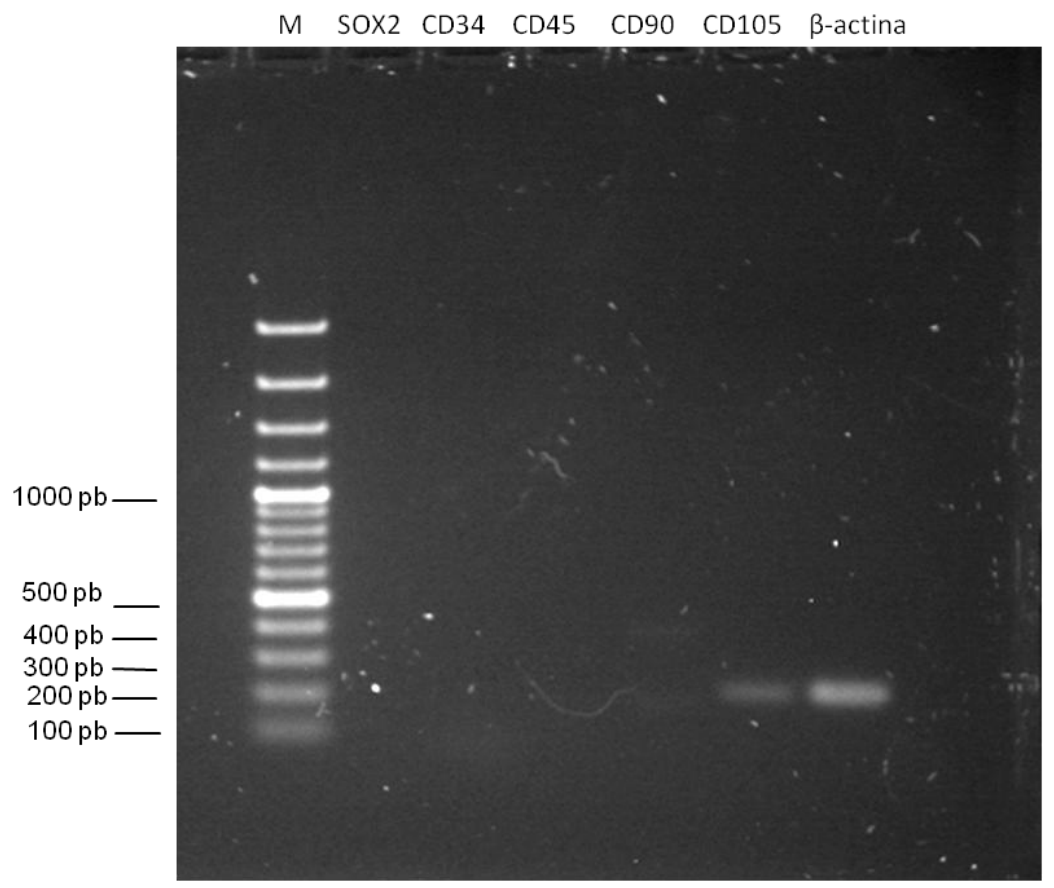

(Fonte: DIAS, J.L.R.M., 2012)

Legenda: O cDNA obtido a partir do RNA foi utilizado como fita molde. Oligonucleotídeos utilizados anelam nos genes SOX2, CD34, CD45, CD90, CD105 e $\beta$ Actina (controle). O produto obtido na RT-PCR foi submetido à corrida eletroforética em gel de agarose $1,5 \%$, sob tensão de $100 \mathrm{~V} / \mathrm{cm} 2$ e corado com SYBR SAFE DNA STAIN antes de ser fotografado pelo sistema Image Quant VDS. Linha 1, M) Marcador de peso molecular DNA ladder de $100 \mathrm{pb}$. Linhas 2) SOX2 (203 pb); Linha 3 CD34 (184pb); Linha 4) CD45 (191pb); Linha 5) CD90 (171pb); Linha 6) CD105 (204pb); Linha 7) $\beta$-acitina(198 pb).

A amplificação da água para todas as reações também foi realizada como controle negativo e não observamos fragmentos como era esperado. 


\subsection{CARACTERIZAÇÃO FUNCIONAL}

\subsubsection{Diferenciação adipogênica}

Com o intuito de avaliar o potencial de diferenciação adipogênico das célulastronco de polpa dentaria de caninos e molares de suínos, exemplares desses dois grupos foram submetidas ao protocolo de diferenciação celular, sendo que transcorridos 14 dias foi realizada a coloração das amostras por oil red, onde foi possível verificar o surgimento de pequenos vacúolos citoplasmáticos com depósitos de lipídios, confirmando a diferenciação adipogênica tanto em amostras derivadas de dentes caninos quanto nas oriundas de molares, ao passo que seus respectivos controles, permaneceram inalterados (Figura 24 e 25, respectivamente).

Figura 24 - Fotomicrografia das células-tronco derivadas de dentes caninos após protocolo de diferenciação adipogênica, submetidas à coloração por oil red
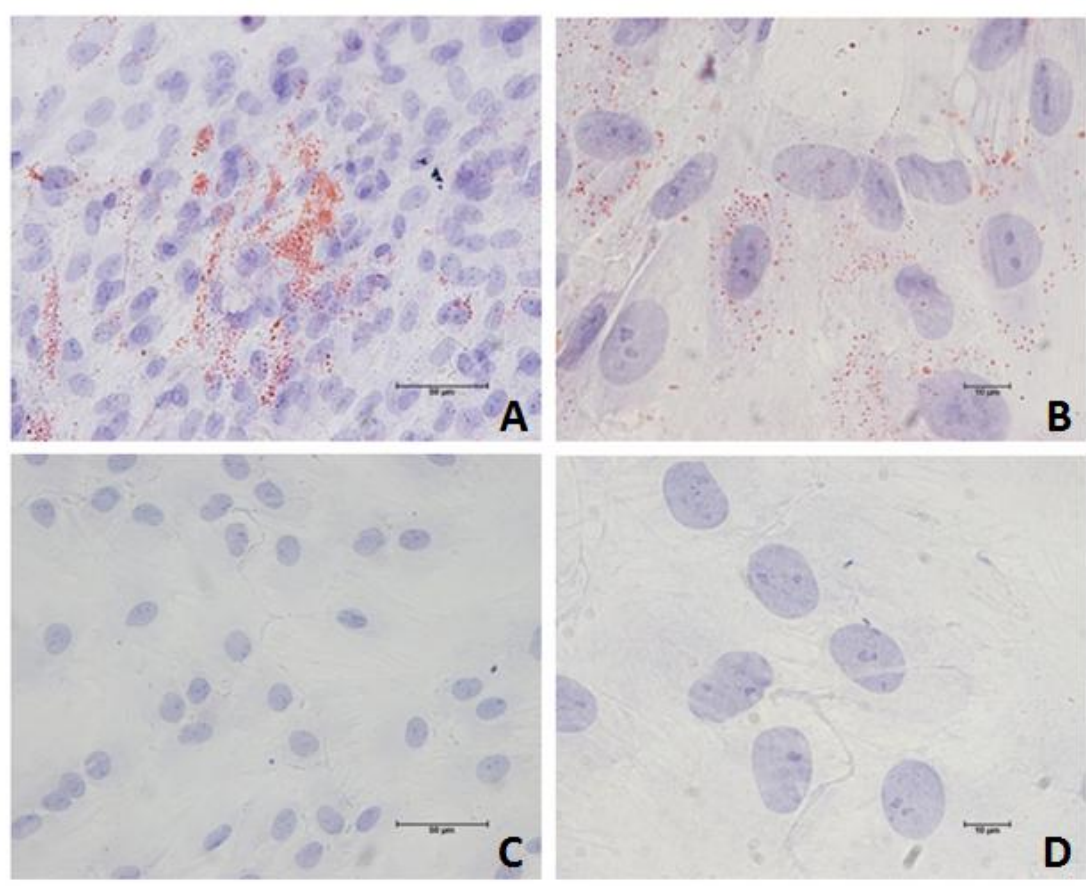

(Fonte: DIAS, J.L.R.M, 2012)

Legenda: $A, B)$ Células-tronco provenientes de polpa dentária de dente canino, submetidas ao meio de indução adipogênico durante 14 dias apresentando inúmeros vacúolos; C, D) controle negativo. Em A,C) aumento de 200x e B,D) 100x 
Figura 25 - Fotomicrografia das células-tronco derivadas de dentes molares após protocolo de diferenciação adipogênica, submetidas à coloração por oil red
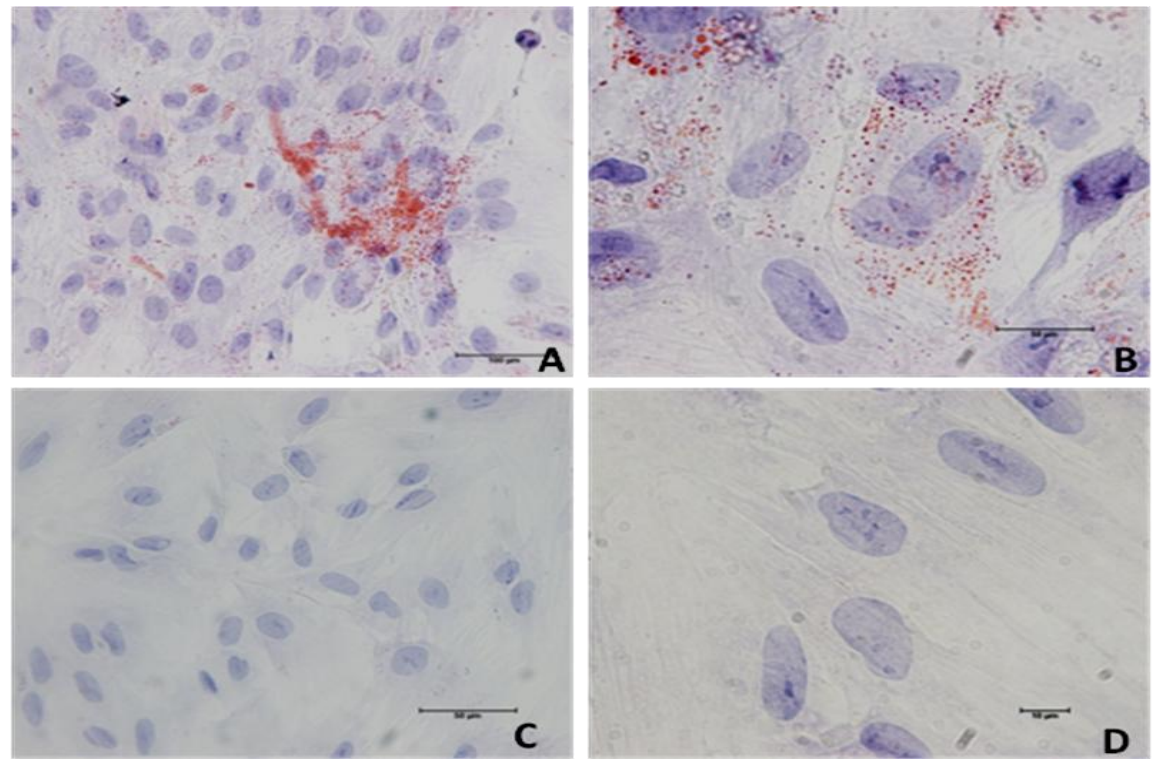

(Fonte: DIAS, J.L.R.M, 2012)

Legenda: A,B) Células-tronco provenientes de polpa dentária de dente molar, submetidas a o meio de indução adipogênico durante 14 dias apresentando inúmeros vacúolos, C,D) controle negativo. Em A,C) aumento de 200x e B,D) 1000x 


\subsubsection{Diferenciação osteogênica}

Ainda com a intenção de avaliar o potencial de diferenciação em osteócitos das células-tronco derivadas de dentes caninos e molares de suínos, estas foram submetidas ao de diferenciação osteogênica e transcorridos 21 dias de protocolo, as amostras foram submetidas à coloração por alizarina red, onde então puderam ser visualizados depósitos de cálcio em arranjos irregulares sobre as culturas celulares derivadas de caninos e molares, representando que houve a diferenciação osteogênica de ambas, uma vez que seus respectivos controles permaneceram inalterados (Figura 26 e 27, respectivamente).

Figura 26 - Fotomicrografia das células-tronco derivadas de dentes caninos após protocolo de diferenciação osteogênica, submetidas à coloração por alizarina red

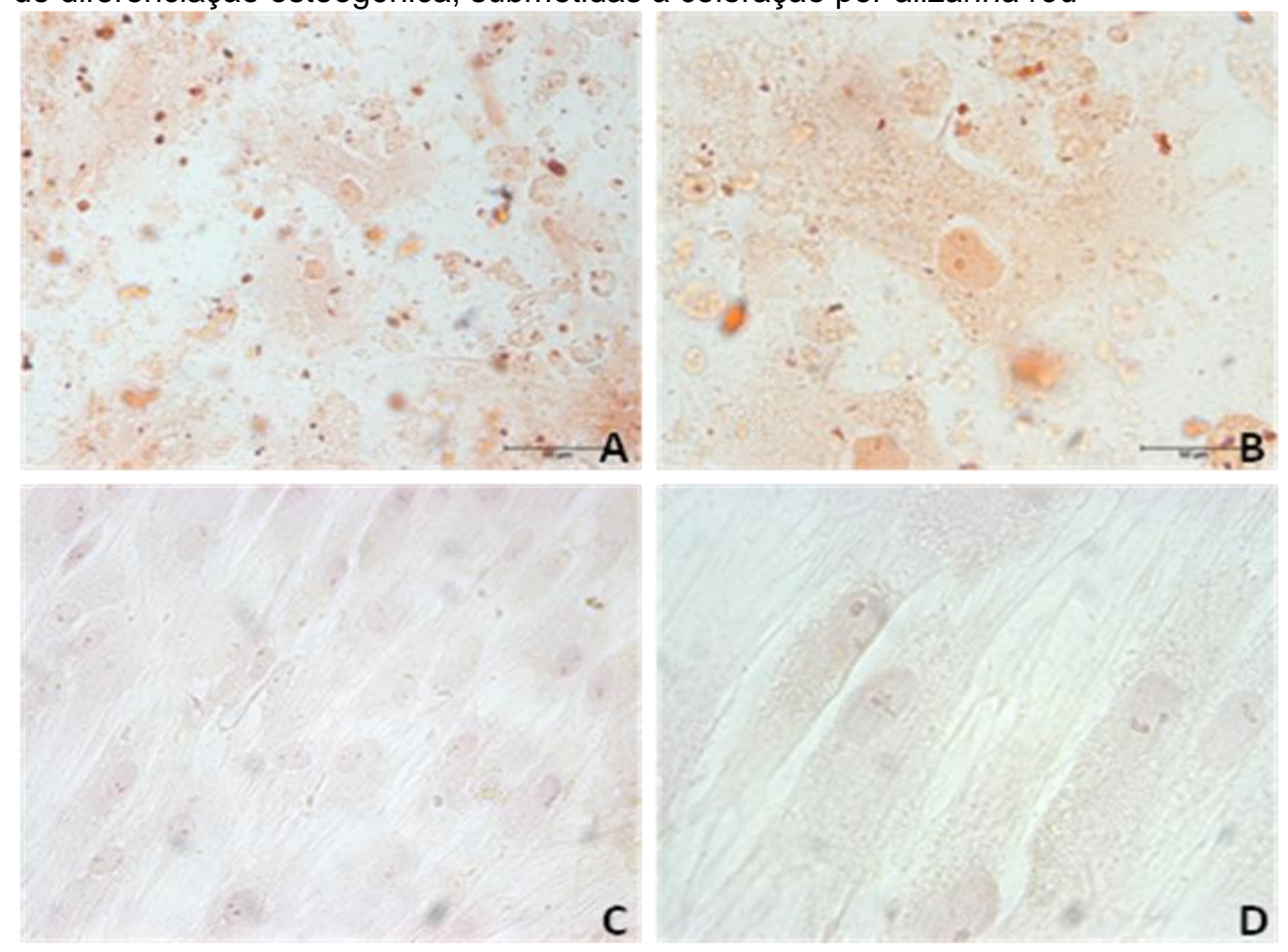

(Fonte: DIAS, J.L.R.M., 2012)

Legenda: $A, B)$ Células-tronco provenientes de polpa dentária de dente canino, submetidas ao meio de indução osteogênico durante 21 dias apresentando depósitos irregulares de cálcio, C,D) canino controle negativo. Em A, C) aumento de 200x e B,D) 1000X. 
Figura 27 - Fotomicrografia das células-tronco derivadas de dentes molares após protocolo de diferenciação osteogênica, submetidas à coloração por alizarina red

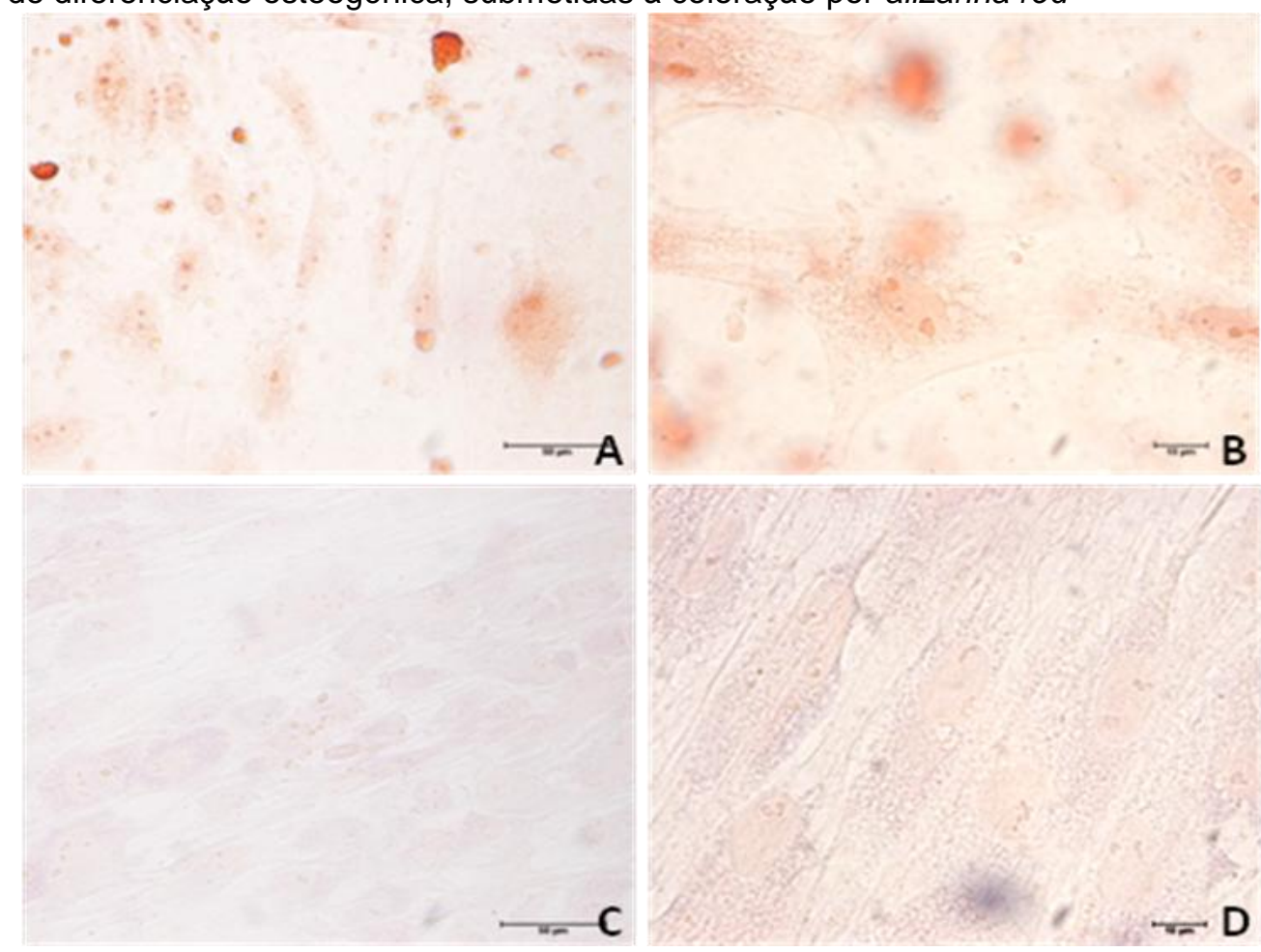

(Fonte: DIAS, J.L.R.M., 2012)

Legenda: $A, B)$ Células-tronco provenientes de polpa dentária de dente molar submetidas a o meio de indução osteogênico durante 21 dias molar apresentando depósitos irregulares de cálcio; C,D) controle negativo. Em A,C) 200x e B,D) 1000X. 


\subsection{ANÁLISE DO POTENCIAL CARCINOGÊNICO DAS CÉLULAS-TRONCO DERIVADAS DE DENTES CANINOS E MOLARES}

Dentro deste aspecto visamos analisar alterações macro e microscópicas após a injeção celular.

\subsubsection{Análise macroscópica após inoculo das células-tronco derivadas de dentes caninos e molares após injeção em camundongos imunossuprimidos nude}

A figura 28 mostra o resultado da análise macroscópica das regiões cervicais antes e após dissecação dos camundongos imunossuprimidos nude em decúbito lateral direito após 60 dias de inoculação com células derivadas de dentes caninos e molares, respectivamente. 
Figura 28 - Análise macroscópica antes e após dissecação da região cervical de camundongos imunossuprimidos, nude que receberam células-tronco de polpa dentária de dentes caninos e molares de suínos, respectivamente.
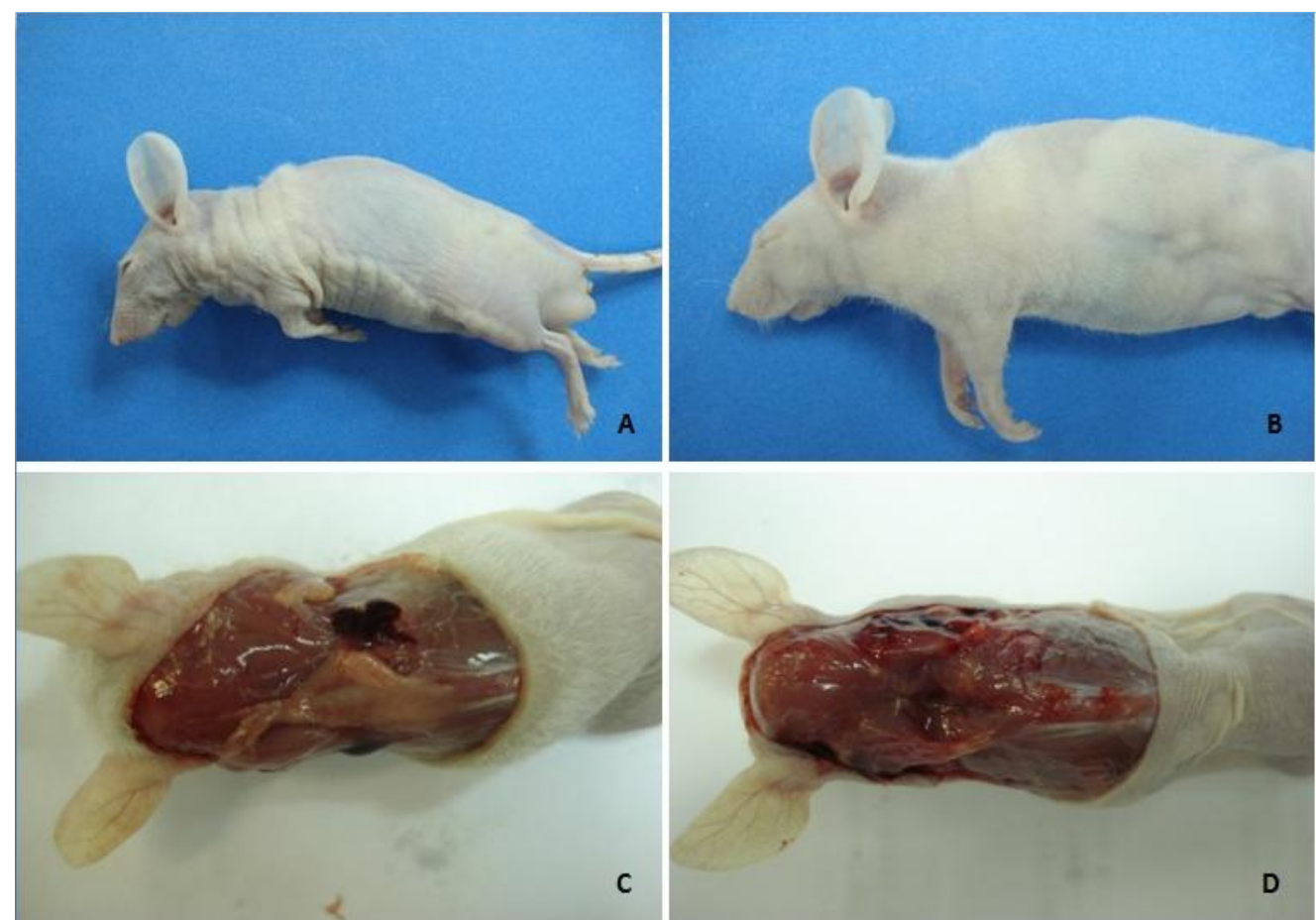

(Fonte: DIAS, J.L.R.M, 2012)

Legenda: A) Análise macroscópica da região cervical de camundongos nude em decúbito lateral-direito oito semanas após a inoculação de células-tronco derivadas de caninos, B) células-tronco de polpa dentária de dentes molares $\mathrm{C}$ ) Análise macroscópica da região cervical após dissecação, canino D) molares. Observe que não houve qualquer indício de formação tumoral.

\subsubsection{Análise histológica dos órgãos dos camundongos imunossuprimidos nude após inoculação das células derivadas de dentes caninos e molares por coloração de Hematoxilina-Eosina}

Nas figuras 29 e 30 foi possível verificar nos resultados apresentados pela histologia do baço, coração, fígado, pulmões e rins dos animais que receberam inoculações de células derivadas dentes caninos e molares, respectivamente, corados por HE que nenhuma das amostras possui metacromasia, discariose e cariomegalia, ao contrário, todas as amostras apresentavam um padrão histológico 
regular para cada tecido, e semelhante ao fisiológico. Além disso, as figuras 29 e $30 \mathrm{~A}$ representam os resultados das análises macroscópicas dos órgãos.

Figura 29 - Análise histológica de órgãos de camundongos imunossupromido nude após 60 dias da inoculação de células-tronco derivadas de dentes caninos, com ausência de indícios de neoplásicos.
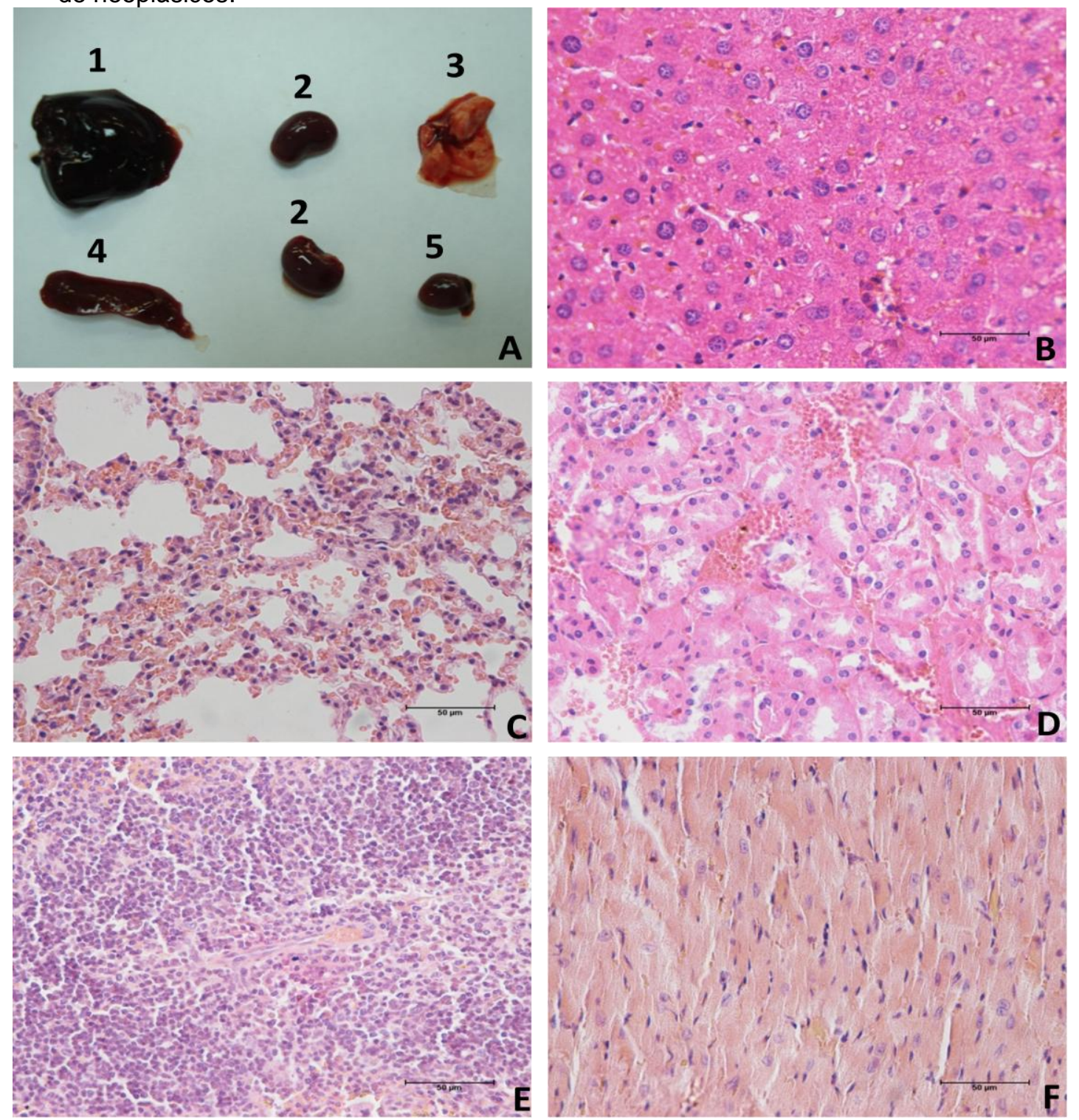

(Fonte: DIAS, J.L.R.M, 2012)

Legenda: A) Análise macroscópica dos órgãos retirados dos camundongos imunossuprimidos nude que receberam inoculação de células-tronco derivadas de dentes caninos sendo: 1 Fígado; 2 - Rins; 3 - Pulmões; 4 - Baço e 5 - Coração. A seguir mostramos a análises microscópicas dos seguintes órgãos: B) Fígado; C) Pulmão; D) Rim; E) Baço e F) Coração, em todas as amostras estão ausentes os padrões indicativos de carcinoma. 
Figura 30 - Análise histológica de órgãos de camundongos imunossupromido nude após 60 dias da inoculação de células-tronco derivadas de dentes molares, com ausência de indícios de neoplásicos
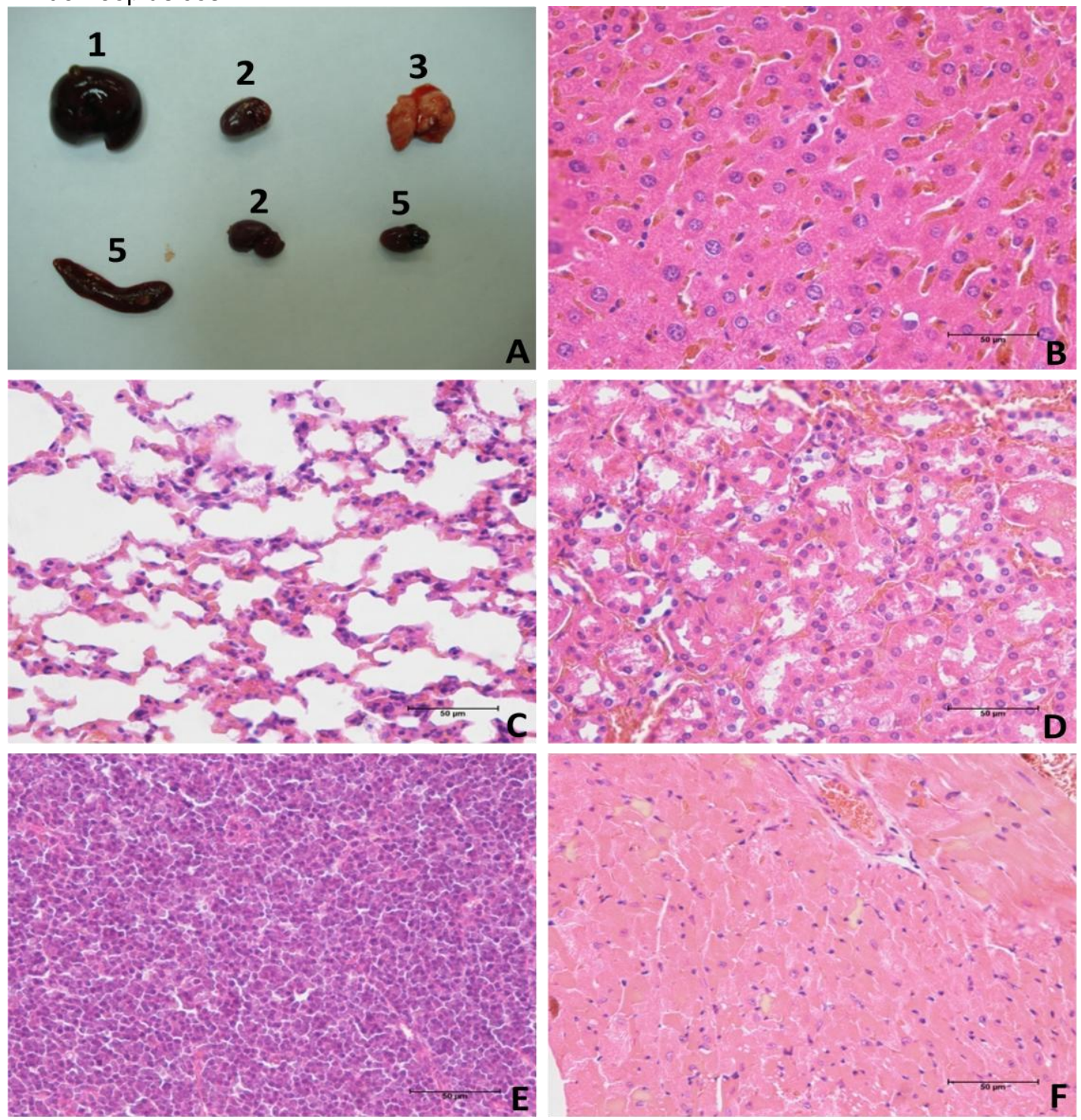

(Fonte: DIAS, J.L.R.M, 2012)

Legenda: A) Análise macroscópica dos órgãos retirados dos camundongos imunossuprimidos nude que receberam inoculação de células-tronco derivadas de dentes molares; 1 - Fígado; 2 - Rins; 3 - Pulmões; 4 - Baço e 5 - Coração. A seguir mostramos as análises microscópicas de: B) Fígado; C) Pulmão; D) Rim; E) Baço e F) Coração, em todas as amostras estão ausente padrões indicativos de carcinoma. 


\section{DISCUSSÃO}

As células-tronco são um tópico bastante explorado nos últimos anos, ampliando suas aplicações e diferentes abordagens na medicina regenerativa. Entretanto, a maior parte do conhecimento que se tem sobre células-tronco até os dias atuais está relacionada às células-tronco humanas, sendo extremamente importante e necessário que isso se amplie para células de animais, para a sua utilização também na área veterinária.

O estudo do suíno como modelo animal é particularmente interessante, uma vez que este animal dentro do grupo dos ungulados é monogástrico, possuindo um estômago apenas, assim como os humanos o que garante uma margem de confiabilidade maior em pesquisas quando comparado a pequenos roedores e não é fastidioso, o que facilita o manejo (PRAVASH et al., 2010).

Nesse projeto nosso objetivo foi estabelecer o cultivo de células-tronco de polpa de dente de suínos, em especial de células-tronco derivadas de caninos, devido ao fato destes dentes apresentarem crescimento contínuo. Dessa forma, células-tronco de polpa de dentária de dentes caninos de suínos foram isoladas e estudadas, ainda pensando em uma análise comparativa, os dentes molares também foram incluídos e estudados em nosso trabalho. Além disso, a similaridade entre os suínos e humanos também foi levada em consideração (IOHARA et al. 2006).

Em relação ao cultivo de células-tronco de polpa dentária de suínos, o método utilizado foi previamente descrito em 2000 por Gronthoset al., revelou ser o método mais coerente que o de Kerkis et al. (2006) que utilizou o método de explante para o isolamento de células-tronco de polpa dentária de dentes decíduos de humanos.

As células foram amplificadas e utilizadas nos experimentos que precederam a caracterização celular, bem como a análise de potencial carcinogênico foi realizada em camundongos nude e nenhuma formação tumoral foi observada. 
As células-tronco de polpa dentária de dentes caninos e molares de suínos quando colocadas em cultivo apresentavam morfologia fibroblastóide semelhantes à morfologia das células-tronco mesenquimais.

As células de polpa dentária de suíno mostraram a expressão CD73 e CD105 e não expressaram os marcadores CD34 e CD45 não apresentaram reação durante a realização da imunohistoquímica, sendo isso uma informação importante uma vez que de acordo com Dominici et al., 2006, as células-tronco mesenquimais expressam CD73, CD105 e CD90 e não expressam CD34 e CD45 bem como HLA-DR, sugerindo que as mesmas possuem características mesenquimais. Também foi observada a expressão dos CD73 e CD105 bem como não expressão de CD45 e CD34 sugerindo características mesenquimais quando fizemos a RT-PCR utilizando oligonucleotídeos específicos para suínos como também foi observado nos estudos de loharaet al. 2006.

Estas células também expressaram vimentina, bem como o marcador de proliferação celular PCNA3 foram positivos em ambas as amostra corroborando com os resultados obtidos no ensaio de MTT onde observamos boa proliferação celular.

Um fator importante que deve ser considerado é que os tecidos dentários provenientes de dentes molares e suínos exibiram uma marcação positiva para marcadores de pluirpotência (Oct-4, Nanog e Sox-2) e esses marcadores não foram encontrados nas células em cultivo sugerindo que aparentemente essas células quando em cultivo diminuem significantemente a expressão dos mesmos e com isso, podemos sugerir que houve diferenciação durante o cultivo.

Quanto a capacidade de diferenciação adipogênica e osteogênica, característica necessária para que seja atribuída a denominação de célula-tronco mesenquimal, tanto as células derivadas de caninos quanto as células derivadas de molares, mostraram-se eficazes, confirmando essa plasticidade através de estímulos para indução específico para cada tipo celular acrescidos ao meio de cultura e infelizmente não foram submetidas ainda a protocolos de diferenciação condrogênicas, o que pode confirmar ainda mais a sua plasticidade, sendo que as diferenciações adipogênicas e condrogênicas foram alcançadas por lohara e colaboradores, 2006. 
No que tange a análise da formação tumoral através do inoculo das células nos animais imunossuprimidos nude, as células-tronco derivadas de polpa dentária de caninos e molares de suínos não apresentaram nenhum indício de formação neoplásica. A mesma função imunossupressora também foi verificada nos trabalhos realizados por Gronthoset al., 2000 e Kerkis et al. 2006, o que confere maior segurança para utilização destas células para Terapia Celular na Medicina Regenerativa. 


\section{CONCLUSÕES}

- Nesse projeto foi possível estabelecer o método de cultivo de células-tronco oriundas de polpa dentária de suínos.

- A técnica de digestão enzimática foi mais eficiente que a de explante para o estabelecimento de cultura de células-tronco derivadas de polpa dentária de suínos (dentes caninos e molares).

- Com base na caracterização celular, molecular e funcional das células-tronco derivadas de polpa dentária de caninos e molares sugerimos que as célulastronco de polpa dentária de dentes caninos e molares de suínos possuem características mesenquimais.

- As células-tronco mesemquimais derivadas de polpa dentária de dentes caninos e molares de suínos não apresentaram indícios de formação tumoral quando inoculadas em camundongos imunossuprimidos podendo ser utilizadas na terapia celular. 


\section{REFERÊNCIAS}

ARGUESO, P.; SPURR-MICHAUD, S.; RUSSO, C.L.; TISDALE, A.; GIPSON, I.K. MUC16 mucin is expressed by the human ocular surface epithelia and carries the H185 carbohydrate epitope. Investigative Ophthalmology Visual Science, v. 44, p. 2487-2495, 2002.

BASSI, E. J.; ITA, C. A. M.; CÂMARA, N. O. S. Immune regulatory properties of multipotent mesenchymal stromal cells: Where do we stand? World J Stem Cells, v. 26, 3(1): -82011.

BRENIVI, T. A. L.; PENNAROSSA G.; GANDOLFI F. No shortcuts to pig embryonic stem cells. Theryogenology, v. 74, p. 544-550, 2010.

CAPLAN, A. I; BRUDER, S. P. Mesenchymal stem cells: building blocks for molecular medicine in the 21st century. Trends in Molecular Medicine, v. 7, p. 259264, 2001.

CAPLAN, A. I. Mesenchymal stem cells and gene therapy. Clinical Orthopedics. Tissue Engineering, v. 11, p. 1198-1211, 2005.

CETESB; Companhia de Tecnologia de Saneamento Ambiental - São Paulo 2009 - Disponível em: <http://www.cetesb.sp.gov.br/tecnologia- ambiental/cas-ematividade/55-camara-ambiental-do-setor-suinocultura>. Acessado em: 20 jun.2011.

COSTA, M.; BUENO, D. F.; MARTINS, M. T.; KERKIS, I.; KERKIS, A.;

FANGANIELLO, R. D. D.; CERRUTI, H.; ALONSO, N.; PASSOS-BUENO, M. R. Reconstruction of large cranial defects in nonimmunosuppressed experimental design with human dental pulp stem cells. The Journal of Craniofacial Surgery, v. 19, p. 204-210, 2008.

DOMINICI ,M.; LE BLANC, K.; MUELLER, I.; SLAPER-CORTENBACH, I.; MARINI, F.; KRAUSE, D. Minimal criteria for defining multipotent mesenchymal stromal cells. The International Society for Cellular Therapy position statement. Cytotherapy, v. 8 n. 4, p. 315-317, 2006.

GRONTHOS, S.; MANKANI, M.; BRAHIM, J.; ROBEY, P. G.; SHI S. Postnatal human dental pulp stem cells (DPSCs) in vitro and in vivo. Proceedings of the National Academy of Sciences USA, v. 97, p. 13625-13630, 2000. 
GRONTHOS, S.; BRAHIM, J.; LI W; FISHER, L. W.; CHERMAN, N.; BOYDE, A.; DENBESTEN, P.; ROBEY, P.; ROBEY, P. G.; SHI S. Stem cell properties of human dental pulp stem cells. Journal of Dental Research, v. 81, p. 531-535, 2002.

HUANG, J. I.; KAZMI, N.; DURBHAKULA, M. M.; HERING, T. M; YOO JU; JOHNSTONE, B. Chondrogenic potencial of progenitor cells derived from human bone marrow and adipose tissue: A patient-matched comparison. Journal of Orthopoedic Research, v. 23, p. 1383-1389, 2008.

IOHARA, K.; ZHENG L.; ITO, M.; TOMOKIYO, A.; MATSUSHITA, K.; NAKASHIMA, $M$. Side population cells isolated from porcine dental pulp tissue with self-renewal and multipotency for dentinogenesis, condrogenesis adipogenesis and neurogenesis. Stem Cells, v. 24 p. 2493-2503, 2006.

IWASSAKI, S.; CHAMPBELL, K. H.; GALLI, C.; AKIYAMA, K. Production os live calves derived form embryonic stem-like cells aggregated with tetraploid embryos. Biology of Reproduction, v. 62, p. 470-475, 2000.

JUNQUEIRA, L.C.; CARNEIRO, J. Histologia básica, Rio de Janeiro: Guanabara Coogan, 10. ed. 2010, p. 287-292.

KEATING, A. Mesenchymal stromal cells. Current Opinion in Hematology, v. 13, p. 419-425, 2006.

KERKIS, I.; KERKIS, A.; DOZORTSEV, D.; STUKART-PARSONS, C. P; MASSIRONI, S. M. G.; PEREIRA, L. V.; CAPLAN, A. I.; CERRUTI, H. F. Isolation and characterization of a population of immature dental pulp stem cells expressing OCT-4 and other embryonic stem cells markers. Cells Tissues Organs. v. 184 n. 34, p. 105-116, 2006.

KERKIS, I. Human immature dental pulp stem cells share key characteristic features with limbal stem cells. Cell Proliferation, v. 42 n. 5, p. 587-594, 2008.

KÖNIG, H. E.; LIEBICH H.G. Anatomia dos Animais Domésticos, Porto Alegre: Artmed, 4. Ed, 2011, p. 323-327. 
LAINO, G.; D'AQUINO, R.; GRAZIANO, A.; LANZA, V.; CARINCI, F.; NARO, F.; PIROZZI, G.; PAPACCIO, G. A new population of human adult dental pulp stem cells: a useful source of living autologous fibrous bone tissue (LAB). Journal of Bone and Mineral Research, v. 20, p. 394-402, 2005.

LEITE SEGUNDO, A. V.; VASCONCELOS, E. C. E. Células-tronco e engenharia tecidual: perspectivas de aplicação em odontologia. Revista de Ciência Médica, v. 16, n. 1, p. 23-30, 2007.

MIURA, M.; GRONTHOS, S; ZHAO M; LU B; FISHER, L. W.; ROBEY, P. G.; SHI S; SHED I. Stem cell from human exfoliated deciduous teeth. Proceedings of the National Academy of Sciences, v. 100, p. 5807-5812, 2003.

MUOTR,I A. R.; MARCHETTO, M. C.; SUZUKI, M. F.; OKAZAKI, K.; LOTFI, C. F.; BRUMATTI, G.; AMARANTE-MENDES, G. P.; MENCK, C. F. Low amounts of the DNA repair XPA protein are sufficient to recover UV-resistance. Carcinogenesis, v. 23, n. 6, p. 1039-46, 2002.

NARDINI, N, B,; MEIRELLES, L. S. Mesenchymal stem cells: isolation, in vitro expansion and characterization. Handbook of Experimental Pharmacology, v. 174, p. 249-282, 2006.

NICKEL, R.; SCHUMMER, A.; SEIFERLE, E. The viscera of the domestic mammals. Berlin: Editora Verlag Paul Parey, 2. ed. 1979, p. 251-254.

PRAVASH, B. V. L. T.; EZASHI, T.; ROBERTS R. M. The promise of stem cell research in pigs and other ungulated species. Stem Cell Review and Reports. v. 6, p. 31-41, 2010.

PIERDOMENICO, L.; BONSI, L.; CALVITTI, M.; RONDELLI, D.; ARPINATI, M.; CHIRUMBOLO, G.; BECCHETTI, E.; MARCHIONNI, C.; ALVIANO, F.; FOSSATI, V.; STAFFOLANI, N.; FRANCHINA, M.; GROSSI, A.; BAGNARA, G. P. Multipotent mesenchymal stem cells with immunosuppressive activity can be easily isolated from dental pulp. Transplantation, v. 80, p. 836-842, 2005. 
SEMEDO, P.; COSTA, M. C.; CENEDEZE, M .A.; MALHEIROS, D. M. A. C.; SHIMIZU, M. H. M.; SEGURO, A. C.; PACHECO-SILVA, A.; NIELS, O. S.; CÂMARA, $\mathrm{N}, \mathrm{O}, \mathrm{S}$. Papel imunossupressor e remodelador das células-tronco mesenquimais em um modelo experimental de doença renal crônica. Revista do Einstein, v. 7, n. 4, p. :469-79, 2009.

SISSON, S. Sistema digestório in GETTY, R. Anatomia dos animais domésticos, Rio de Janeiro: Guanabara Coogan, 5. ed. 1986, p. 1188-1190.

TANG, R.; DING, G. Swine dental pulp stem cell inibit t-cell proliferation.

Trasnplantation Proceedings, v. 43, p. 3955-3959, 2011.

VENTURINI, S. A. O abate de suínos. Relatório técnico da Universidade Federal do Espírito Santo - UFES 2009 - Disponível em <http://www.agais.com/telomc/b01 407_abate_suinos.pdf> Acessado em: 20 jun 2011

YAMAMURA, T. Differentiation of pulpal cells and inductive influences of various matrices with reference to pulpal wound healing. Journal of Dental Research, v. 64, p. 530-540, 1985.

ZANG, L. P. K.; NAKAMURA, T.; INATOMI, T.; SOTOZONO, C.; KOIZUMI, N,; YOKOI ,N.; KINOSHITA, S. Autologous Serum-Derived Cultivated Oral Epithelial Transplants for Severe Ocular Surface Disease. Archives of Ophthalmol, v. 124, p. 1543-1555, 2006. 